Ricardo dos Santos Coelho

\title{
AVALIAÇÃO DA TOXICIDADE DE FLUIDOS DE USINAGEM ATRAVÉS DA ECOTOXICOLOGIA AQUÁTICA.
}

\begin{abstract}
Tese apresentada à Escola de
Engenharia de São Carlos como parte dos requisitos para a obtenção do Título de Doutor em Ciências da Engenharia Ambiental.
\end{abstract}

Orientadora: Profa Dra. Eny Maria Vieira

São Carlos 
Ficha catalográfica preparada pela Seção de Tratamento da Informação do Serviço de Biblioteca - EESC/USP

Coelho, Ricardo dos Santos

Avaliaçăo da toxicidade de fluidos de usinagem através da ecotoxicologia aquática / Ricardo dos Santos Coelho -São Carlos, 2006.

Tese (Doutorado) -- Escola de Engenharia de São Carlos-Universidade de São Paulo, 2006.

Área: Engenharia Ambiental.

Orientadora: Profa. Dra. Eny Maria Vieira.

1. Degradação. 2. Eluidos de corte. 3. Bioensaios.

4. Ecotoxicologia aquática. I. Título. 
FOLHA DE JULGAMENTO

Candidato: Bacharel RICARDO DOS SANTOS COELHO

Tese defendida e julgada em 10/10/2006 perante a Comissão Julgadora:

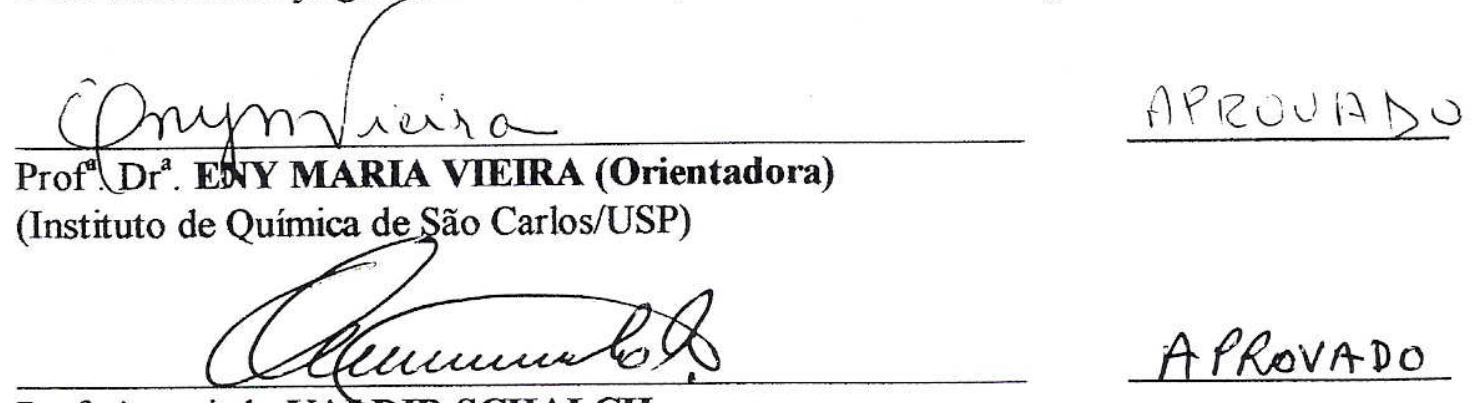

Prof. Associado VACDIR SCHALCH

(Escola de Engenharia de São Carlos/USP)

Cuslencif.P. Paschocilalo AProvado Prof ${ }^{a}$. ${ }^{2}{ }^{a}$. CRISTINA FULOMENA PEREIRA ROSA PASCHOALATO

(Universidade de Ribeirão Preto/UNAERP)

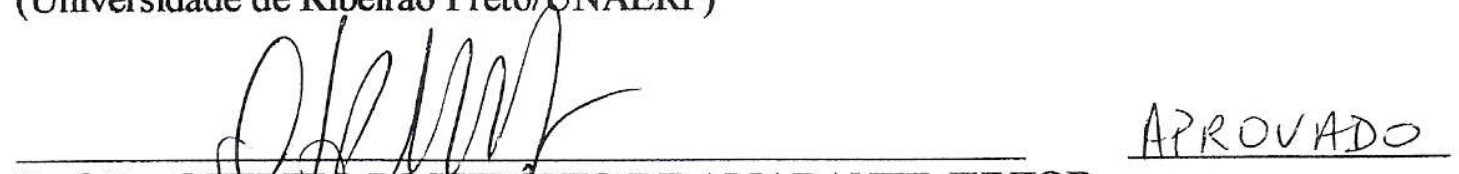

Prof. Dr. OZLLIT́O POSSIDÓNIO DE AMARANTE JUNIOR

(Centro Federal de Educação Tecnológica do Maranhão/CEFET-MA)

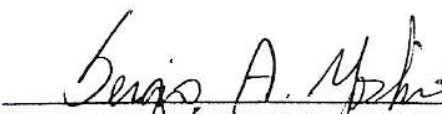

Prof. Dr.SEERGIO AKINOBU YOSHIOKA

(Instituto de Química de São Carlos/USP)
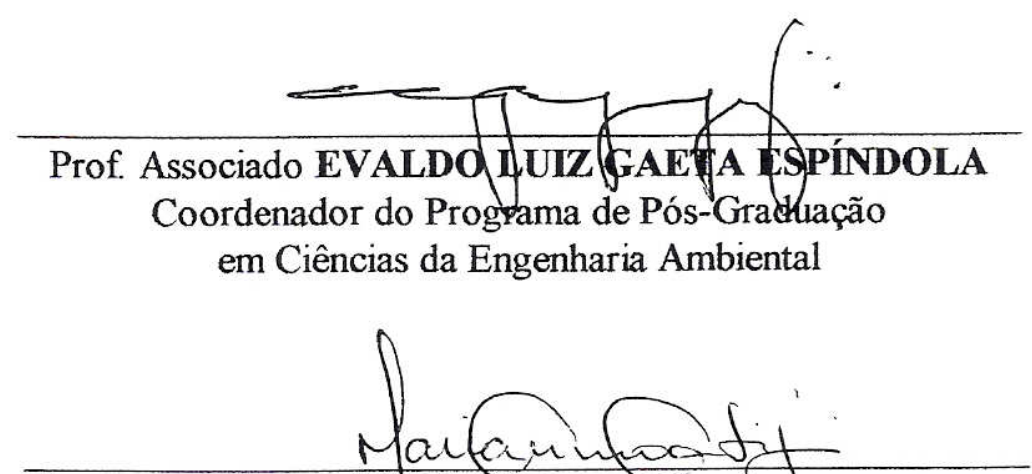

Profa. Titular MARIA DO CARMO CALIJURI

Presidente da Comissão de Pós-Graduação 
"O sábio envergonha-se dos seus defeitos, mas não se envergonha de corrigi-los." (Confúcio). 
'Há homens que perdem a saúde para juntar dinheiro e depois perdem o dinheiro para recuperar a saúde. Por pensarem ansiosamente no futuro, esquecem o presente, de tal forma que acabam por nem viver no presente nem no futuro. Vivem como se nunca fossem morrer e morrem como se nunca tivessem vivido..." (Confúcio). 
Aos meus pais, Silvio e Geraldina, por todo o incentivo e apoio dedicados ao longo de toda a minha vida. 


\section{AGRADECIMENTOS}

À Prof ${ }^{a}$ Dra. Eny Maria Vieira, pela paciência, orientação e amizade, confiadas a mim ao longo desses anos. Pelo exemplo de dedicação a vida acadêmica e aos seus alunos;

Á Dra Sueli Ivone Borrely, por ter me apoiado nos momentos mais difíceis neste doutorado. Pelo carinho e amizade vindos deste grande ser humano, com um coração gigantesco e uma alma resplendorosa;

A Dra Maria Beatriz Bohrer-Morel pela inspiração, amizade e dedicação que há muito faz parte de minha vida;

Ao Prof. Dr. Evaldo Luiz Gaeta Junior, por me receber de braços abertos no programa de doutorado deste centro. Sempre com muita alegria e paciência;

A Prof ${ }^{a}$ Dra. Odete Rocha, pela inspiração e exemplo de dedicação que por toda a sua vida vem demonstrando;

Ao grande amigo Prof Dr. Ozeltio Possidônio Amarante Junior, pelo seu apoio singular, seus conselhos e sua alegria os quais me fizeram prosseguir e finalizar este trabalho;

A MSc. Antônia Queiroz Lima de Souza, por sua enorme contribuição nos testes microbiológicos;

Aos amigos Natilene Mesquita Brito e Alan Duboc Birches Lopes (Parmito), pelo incentivo, amizade e dedicação que sempre tiveram comigo;

Ao amigo Cláudio Turene, pelo companheirismo e amizade a mim demonstrados;

Aos técnicos do CRHEA e do IQSC, por sua pronta colaboração sempre que solicitados;

A CAPES. 


\section{RESUMO}

COELHO, R. S. (2006). AVALIAÇÃO DA TOXICIDADE DE FLUIDOS DE USINAGEM ATRAVÉS DA ECOTOXICOLOGIA AQUÁTICA. Tese (Doutorado) - Escola de Engenharia de São Carlos, Universidade de São Paulo, São Carlos, 2006.

Análises ecotoxicológicas vêm sendo amplamente empregadas no monitoramento de amostras ambientais, efluentes industriais e substâncias complexas. Com o objetivo de avaliar a toxicidade de fluidos de usinagem usados na indústria de peças metálicas, foram feitos ensaios de toxicidade aguda com espécies de três diferentes níveis tróficos: Vibrio fischeri, Daphnia similis, Daphnia laevis e Danio rerio. As amostras dos fluidos foram também analisadas quanto aos valores de $\mathrm{DQO}$, fenol, $\mathrm{pH}$, cor, densidade e surfactantes. Os parâmetros físicos e químicos encontram-se dentro dos limites da legislação CONAMA 357 (D.O.U.,2005). Os resultados dos bioensaios revelaram que os fluidos de usinagem apresentaram toxicidade aos organismos empregados neste estudo, e que o tratamento das amostras com radiação gama não foi eficiente na diminuição da toxicidade dessas matrizes. Foi observado que a radiação gama potencializou o efeito tóxico dos fluidos estudados. A biodegradação em solo demonstrou ser efetiva para os fluidos de usinagem e bactérias endêmicas foram identificadas e isoladas para possível utilização no tratamento de áreas contaminadas com fluidos de usinagem. $O$ monitoramento e gestão dos resíduos de fluido de usinagem são necessários para a preservação dos organismos aquáticos devido a sua toxicidade elevada.

Palavras-chave: fluidos de usinagem, bioensaios, ecotoxicologia aquática. 
ABSTRACT

COELHO, R. S. (2006). EVALUATION OF THE TOXICITY OF FLUIDS EMPLOYED IN THE METALLIC TOOL INDUSTRIAL MACHINING USING AQUATIC ECOTOXICOLOGY. PhD Thesis - Escola de Engenharia de São Carlos, Universidade de São Paulo, São Carlos, 2006.

Ecotoxicological analyses have being used to monitor environmental samples, industrial effluents and complex substances. With the objective to analyze the toxicity of cutting fluids used in the machinery industry, acute toxicity test with species of three different throphic levels: Vibrio fischeri, Daphnia similis, Daphnia laevis e Danio rerio, were performing. The samples of fluids were analyzed by $\mathrm{COD}$, phenol, $\mathrm{pH}$, color, density and surfactants. The physical and chemical parameters are the according with the Brazilian law, CONAMA 357 (D.O.U. 2005\}. The results of the toxicity tests showed that the cutting fluids have high toxicity to the organisms used in this study and the gamma radiation treatment was not efficient to decrease the matrix. The biodegradation in soil demonstrated be effective to the cutting fluids and the indigenous bacteria were identified and isolated to possible treatment of soils contaminated with these kinds of substances. The monitoring and management of residues of cutting fluids are necessary to preservation of aquatic live, in consequence of their high toxicity.

Key-words: cutting fluids, toxicity tests, aquatic ecotoxicology. 


\section{Lista de Figuras}

Figura 1.1 - Fotografia de sistema empregando fluido de corte.

Figura 1. 2 - Material usado que normalmente se descarta indiscriminadamente.

Figura 2.1 - Dinâmica dos óleos no ambiente (adaptada de TRETT, 1989 apud AMARANTE JR, 2003).

Figura 2.2 - Derramamento acidental de óleo em corpo d’água.

Figura 2.3 - Operação de limpeza do acidente com o navio Exxon Valdez.

Figura 2.4 - Daphnia sp; descrição da morfologia interna e externa.

Figura 2.5 - Daphnia sp; descrição do ciclo de vida.

Figura 2.6 - Foto de uma câmara de incubação.

Figura 2.7 - Foto de ovo de resistência (Efípio) de Daphnia sp

Figura 2.8 - Ilustração do princípio de funcionamento de acelerador de elétrons.

Figura 4.1 - Fêmea embrionada de Daphnia similis.

Figura 4.2 - Daphnia laevis adulta.

Figura 4.3 - Reservatório Aldeia da Serra, Barueri, São Paulo,SP.

Figura 4.4 - Sistema Metropolitano de Abastecimento, em destaque a localização da Represa Paiva Castro, Mairiporã, São Paulo, SP.

Figura 4.5 - Represa Paiva Castro, Mairiporã, São Paulo, SP.

Figura 4.6 - Danio rerio adulto

Figura 4.7 - Esquema de montagem do experimento de degradação.

Figura 4.8 - Procedimento utilizado no preparo das amostras. 
Figura 5.1 - Resultados da toxicidade da amostra de fluido mineral sem uso (A) a espécie Daphnia similis.

Figura 5.2 - Resultados da toxicidade da amostra de fluido mineral usado (A') 85 a espécie Daphnia similis.

Figura 5.3 - Resultados da toxicidade da amostra de fluido semi-sintético sem uso (B) a espécie Daphnia similis.

Figura 5.4 - Resultados da toxicidade da amostra de fluido semi-sintético usado (B') a espécie Daphnia similis.

Figura 5.5 - Resultados da toxicidade da amostra de fluido sintético sem uso (C) a espécie Daphnia similis.

Figura 5.6 - Resultados da toxicidade da amostra de fluido sintético usado (C') 89 a espécie Daphnia similis.

Figura 5.7 - Resultados da toxicidade da amostra de fluido mineral sem uso 92 (A) para a espécie Daphnia laevis.

Figura 5.8 - Resultados da toxicidade da amostra de fluido mineral usado (A') 92 para a espécie Daphnia laevis.

Figura 5.9 - Resultados da toxicidade da amostra de fluido semi-sintético sem 94 uso (B) para a espécie Daphnia laevis.

Figura 5.10 - Resultados da toxicidade da amostra de fluido semi-sintético usado (B') para a espécie Daphnia laevis.

Figura 5.11 - Resultados da toxicidade da amostra de fluido sintético sem uso 96 (C) para a espécie Daphnia laevis.

Figura 5.12 - Resultados da toxicidade da amostra de fluido sintético usado (C') 96 para a espécie Daphnia laevis.

Figura 5.13 - Sensibilidade de Daphnia laevis ao dicromato de potássio. 
Figura 5.14 - Sensibilidade de Daphnia similis ao dicromato de potássio.

Figura 5.15 - Sensibilidade de Daphnia laevis ao cloreto de sódio.

Figura 5.16 - Sensibilidade de Daphnia similis ao cloreto de sódio

Figura 5.17 - Resultados dos testes de toxicidade do fluido mineral sem uso 104 (preto) e usado (azul) para Danio rerio.

Figura 5.18 - Resultados dos testes de toxicidade dos fluidos $B$ (preto) e 105 $B^{\prime}(a z u l)$ para Danio rerio.

Figura 5.19 - Resultados dos testes de toxicidade das amostras de fluido $C$ 106 (preto) e C'(azul) para Danio rerio. 


\section{Lista de Tabelas}

TABELA 2.1 - Componentes dos fluidos estudados por AMARANTE JR. (2004).

TABELA 2.2 - Aditivos usados em fluidos de corte (Adaptada da revista de 16 LUBRIFICAÇÃO, 1986).

Tabela 4.1 - Parâmetros físicos e químicos avaliados no estudo das 45 amostras de óleo $A, A^{\prime}, B, B$ ', $C$ e $C$.

Tabela 5.1 - Parâmetros físicos e químicos da amostra de fluido A (fluido $\quad 70$ mineral sem uso)

Tabela 5.2 - Parâmetros físicos e químicos da amostra de fluido A' (fluido 71 mineral usado).

Tabela 5.3 - Parâmetros físicos e químicos da amostra de fluido B (semi - 71 sintético sem uso).

Tabela 5.4 - Parâmetros físicos e químicos da amostra de fluido B' (semi 72 sintético usado).

Tabela 5.5 - Parâmetros físicos e químicos da amostra de fluido C (polímero 72 sintético sem uso).

Tabela 5.6 - Parâmetros físicos e químicos avaliados no estudo das amostras de 73 óleo C' (polímero sintético usado).

Tabela 5.7 - Concentração letal a 50 \% dos indivíduos para a amostra A (fluido mineral sem uso).

Tabela 5.8 - Concentração letal a 50 \% dos indivíduos para a amostra A' (fluido mineral usado).

Tabela 5.9 - Valores da concentração letal a $50 \%$ dos indivíduos para a amostra $B$ (fluido semi - sintético sem uso).

Tabela 5.10 - Valores da concentração letal a 50 \% dos indivíduos para a 
amostra B' (fluido semi - sintético usado).

Tabela 5.11 - Concentração letal a 50 \% dos indivíduos para a amostra C 80 (fluido sintético sem uso).

Tabela 5.12 - Concentração letal a 50 \% dos indivíduos para a amostra C' 80 (fluido sintético usado).

Tabela 5.13 - Sistema de classificação da toxicidade aguda

Tabela 5.14 - Classificação de toxicidade adotada a partir dos valores do 82 efeito gama $(\Gamma)$.

Tabela 5.15 - Testes de toxicidade das amostras de fluido mineral sem uso 84 (amostra A) a espécie Daphnia similis.

Tabela 5.16 - Testes de toxicidade das amostras de fluido mineral usado 84 (amostra A') a espécie Daphnia similis..

Tabela 5.17 - Testes de toxicidade das amostras de fluido semi-sintético 86 sem uso (amostra B) a espécie Daphnia similis.

Tabela 5.18 - Testes de toxicidade das amostras de fluido semi-sintético 86 usado (amostra B') a espécie Daphnia similis.

Tabela 5.19 - Testes de toxicidade das amostras de fluido sintético sem 88 uso (amostra C) a espécie Daphnia similis.

Tabela 5.20 - Testes de toxicidade das amostras de fluido sintético usado 88 (amostra C') a espécie Daphnia similis.

Tabela 5.21 - Testes de toxicidade das amostras de fluido mineral sem uso (amostra A) para a espécie Daphnia laevis.

Tabela 5. 22 - Testes de toxicidade das amostras de fluido mineral usado (amostra A') para a espécie Daphnia laevis.

Tabela 5. 23 - Testes de toxicidade das amostras de fluido semi-sintético 
sem uso (amostra B) para a espécie Daphnia laevis.

Tabela 5. 24 - Testes de toxicidade das amostras de fluido semi-sintético 93 usado (amostra B') para a espécie Daphnia laevis.

Tabela 5. 25 - Testes de toxicidade das amostras de fluido sintético sem 95 uso (amostra C) para a espécie Daphnia laevis.

Tabela 5.26 - Testes de toxicidade das amostras de fluido sintético usado 95 (amostra C') para a espécie Daphnia laevis

Tabela 5.27 - Sensibilidade de D. laevis ao dicromato de potássio.

Tabela 5.28 - Sensibilidade de D. similis ao Dicromato de Potássio.

Tabela 5.29 - Sensibilidade de D. laevis ao cloreto de sódio.

Tabela 5.30 - Sensibilidade de D. similis ao cloreto de sódio.

Tabela 5.31 - Testes de toxicidade do fluido mineral sem uso, amostra A 104 empregando a espécie Danio rerio.

Tabela 5.32 - Testes de toxicidade do fluido mineral usado, amostra A' 104 empregando a espécie Danio rerio.

Tabela 5.33 - Testes de toxicidade do fluido semi-sintético sem uso, 105 amostra B, empregando a espécie Danio rerio.

Tabela 5.34 - Testes de toxicidade do fluido semi-sintético usado, amostra 105 B', empregando a espécie Danio rerio.

Tabela 5.35 - Testes de toxicidade do fluido sintético sem uso, amostra C, 106 empregando a espécie Danio rerio.

Tabela 5.36 - Testes de toxicidade do fluido sintético usada, amostra C', 106 empregando a espécie Danio rerio.

Tabela 5.37 - Testes de viabilidade da água para cultivo de organismos 108 aquáticos. 
Tabela 5.38 - Toxicidade aguda da amostra de fluido mineral sem uso 109 irradiada com $10 \mathrm{kGy}$ frente a bactéria $\mathrm{V}$. fischeri .

Tabela 5.39 - Toxicidade aguda de fluido mineral usado irradiada com 10109 kGy frente a bactéria $V$. fischeri .

Tabela 5.40 - Toxicidade aguda das amostras de fluido semi-sintético sem uso irradiada com 10 kGy frente a bactéria $V$. fischeri .

Tabela 5.41 - Toxicidade aguda de fluido semi-sintético usado irradiada com 110 10 kGy frente a bactéria $V$. fischeri .

Tabela 5.42 - Toxicidade aguda de fluido sintético sem uso irradiada com 10111 kGy frente a bactéria $V$. fischeri .

Tabela 5.43 - Toxicidade aguda de fluido sintético usado irradiada com 10111 kGy frente a bactéria $V$. fischeri .

Tabela 5.44 - Toxicidade aguda do fluido mineral sem uso irradiada com 100 kGy 112 frente a bactéria $V$. fischeri .

Tabela 5.45 - Toxicidade aguda do fluido mineral usado irradiada com 100 kGy 112 frente a bactéria $V$. fischeri .

Tabela 5.46 - Toxicidade aguda do fluido semi-sintético sem uso, irradiada com 100112 kGy frente a bactéria $V$. fischeri .

Tabela 5.47 - Toxicidade aguda do fluido semi-sintético usado irradiada com 100112 kGy frente a bactéria $V$. fischeri .

Tabela 5.48 - Toxicidade aguda do fluido sintético sem uso irradiada com 100 kGy 113 frente a bactéria $V$. fischeri .

Tabela 5.49 - Toxicidade aguda do fluido sintético usado irradiada com 100 kGy frente a bactéria $V$. fischeri .

Tabela 5.50. Denominação das bactérias encontradas nas amostras de fluido de usinagem, sua similaridade e espécie. 


\section{SUMÁRIO}

1. INTRODUÇÃO

1.1 Avaliação e Monitoramento da Qualidade da Água 2

1.2. Ecotoxicologia 4

1.3. Natureza da Poluição

1.4. Fluidos Industriais de Usinagem $\quad 7$

2. CONSIDERAÇÕES TEÓRICAS 9

2.1 Efeitos dos poluentes e o Monitoramento ambiental 9

2.2. Poluição Orgânica 11

2.2.1. Componentes Orgânicos e Toxicidade 12

2.2.2. Amostras de fluidos de corte (uma mistura complexa) 14

2.3. O Despejo de Fluidos no Ambiente e sua Dinâmica 17

$\begin{array}{ll}\text { 2.3.1. Contaminação do Meio } & 18\end{array}$

2.3.2. Dinâmica e Destino 19

2.4. Legislação Aplicável $\quad 27$

2.4.1. Resolução CONAMA 09/93 28

2.4.2. Agencia Nacional de Petróleo e suas funções 30

2.4.3. Resolução CONAMA 357 (17/03/2005) 30 
4.1. Caracterização das amostras e determinação das variáveis físicas e químicas.

4.3. Caracterização das amostras e determinação das variáveis físicas e químicas. 
4.7. Testes de toxicidade com peixes - Danio rerio - Teleostei, Cyprinidae. contaminados.

4.9.1. Testes de Biodegradabilidade

4.9.2. Identificação de Microrganismos Decompositores

4.9.3. Identificação de bactérias por ácidos graxos.

5.1. Determinação das variáveis físicas e químicas dos fluidos de usinagem. 
5.2.2. Testes Agudos em amostras de fluidos de usinagem empregando-se Daphnias, família Daphnidae, Ordem Cladocera.

5.2.1. Daphnia similis

5.2.2.2. Daphnia laevis

5.2.2.3. Testes de sensibilidade para os organismos usados nos testes

5.2.2.3.1. Testes de sensibilidade com dicromato de potássio $\left(\mathrm{K}_{2} \mathrm{Cr}_{2} \mathrm{O}_{7}\right)$

5.2.2.3.2. Teste de sensibilidade com cloreto de sódio $(\mathrm{NaCl})$

5.2.2.4. Testes de toxicidade dos fluidos empregando-se peixes - Danio rerio

- Teleostei, Cyprinidae.

5.2.2.5. Viabilidade da Água de Cultivo.

5.2.3. Testes de toxicidade das amostras de fluidos após a irradiação

5.5. Testes de Biodegradabilidade

5.5.1. Testes de biodegradação em ambientes aquáticos.

5.5.2. Biorremediação de solo

6. CONSIDERAÇÕES FINAIS 


\section{INTRODUÇÃO}

O planeta Terra, existe há aproximadamente 4,6 bilhões de anos e nesse período passou por inúmeras catástrofes, que de uma forma ou outra, sempre causaram desequilíbrio aos sistemas naturais. Contudo, os acidentes naturais eram ao longo do tempo superados através de processos de equilíbrio dinâmico ao qual Darwin denominou Evolução (COELHO, 2001).

Com o surgimento do ser humano, ocorreram transformações radicais no meio ambiente. Desta forma, a Terra passa a ter danos ambientais significativos e constantes, os quais, a tornam incapaz de absorvê-los e conseqüentemente equilibrar-se em um curto período de tempo.

No século XVIII, com o surgimento da revolução industrial e o crescimento das formas de produção e consumo, aumentou o impacto de origem antrópica e os riscos a estes associados. Novas tecnologias desenvolvidas pelo homem em todas as áreas da ciência, acarretaram problemas cada vez maiores, sendo que a escala, a freqüência e os danos causados por acidentes, ou influenciados pela ação humana, foram também potencializados (COELHO, 2001). Por quase 200 anos um grande número de abusos à natureza ocorreram, pois não havia nenhum controle por parte das autoridades quanto ao que se produzia e como isto se dava. Somente em torno de 1960, após alguns graves acidentes com produtos químicos e o surgimento do livro Primavera Silenciosa (Silent Spring, CARSON, 1962), é que houve o interesse da sociedade em diminuir os danos causados ao meio ambiente, destacando-se, uma grande preocupação em relação aos ecossistemas aquáticos. 
A água é de grande importância para todos os seres do planeta, ela é necessária para a manutenção da vida, o que justifica todo e qualquer cuidado que objetiva a preservação de sua qualidade e quantidade.

Embora os ecossistemas aquáticos apresentem uma série de mecanismos físicos, químicos e biológicos, para a assimilação de substâncias tóxicas, quando estas atingem níveis acima da capacidade assimilativa do meio receptor, afetam a sobrevivência, o crescimento e a reprodução dos organismos que ali vivem degradando a qualidade das águas. Desta forma, tornam-se obrigatórias ações voltadas para diminuir a poluição causada pelo homem, tais como, o uso racional dos recursos naturais, tratamento de efluentes, desenvolvimento de tecnologias para a recuperação de corpos hídricos contaminados (AMARANTE JR, 2003).

\subsection{Avaliação e Monitoramento da Qualidade da Água}

Entre os recursos naturais, a água é um dos mais importantes e também um dos mais suscetíveis a impactos decorrentes de atividades antrópicas. A constante utilização deste recurso tem requerido um grande número de estudos para avaliar e manter sua qualidade. Segundo CHAPMAN (1989), o monitoramento do ambiente além de fornecer informações importantes sobre a extensão da poluição, e seus prováveis impactos, também avalia a eficiência de ações mitigadoras, adotadas com o propósito de diminuir ou mesmo eliminar sua origem, tornando-se importantes para a avaliação do grau de degradação ambiental.

Tradicionalmente, as análises físicas e químicas são as mais usadas na classificação de resíduos, tanto de origem industrial e rural, como doméstica. Porém, estas têm apenas detectado as concentrações e alterações no tempo e no espaço, sendo que as respostas biológicas às mudanças ambientais e à 
ação dos contaminantes, foram conhecidas apenas após a introdução de métodos biológicos de análise. No monitoramento físico e químico, tem-se como principal vantagem o desenvolvimento de novas técnicas analíticas que podem detectar baixas concentrações de contaminantes em um curto período de tempo. Entretanto apresenta grandes desvantagens, como por exemplo, os custos elevados dos equipamentos e reagentes, e o fato dos efeitos biológicos e sinérgicos das substâncias químicas não serem avaliados.

Neste aspecto, o monitoramento biológico é eficaz na identificação de mecanismos e efeitos em níveis de organização biológica, principalmente, quando associados ao monitoramento simultâneo da sensibilidade ao estresse, à integração das respostas às concentrações de poluentes e à avaliação dos efeitos sinérgicos e antagônicos dos mesmos (ADAMS, 1990). Porém, tais indicadores também apresentam limitações, como a quantificação de respostas bioquímicas e moleculares que necessitam de equipamentos sofisticados.

Basicamente, pode-se dividir o biomonitoramento em duas partes distintas: passivo ou bioavaliações, que são análises das comunidades biológicas que precisam de controles experimentais rígidos; e o ativo ou bioensaios, que são testes em laboratório ou in situ que requerem rigorosos procedimentos experimentais que avaliam a toxicidade das substâncias aos organismos (BURTON, 1994).

Vários organismos podem ser utilizados como detectores de problemas causados ao meio ambiente, sendo denominados bioindicadores e segundo JEFFREY (1987) apud PAMPLIM (1999), eles podem ser definidos como organismos selecionados com os quais pode-se amostrar, testar e responder às questões ambientais.

$\mathrm{Na}$ realização do biomonitoramento, uma espécie ou grupo de organismos somente é utilizada quando apresenta algumas características que as tornem "ideais", dentre as quais ampla distribuição, abundância numérica, 
baixa variabilidade genética, além de uma taxonomia estável, bem definida e fácil de ser reconhecida (RAND \& PETROCELLI, 1985).

\subsection{Ecotoxicologia}

O interesse em estudar os danos causados por poluentes nas comunidades aquáticas e nos seus níveis de organização fez com que a Ecotoxicologia Aquática tivesse um grande desenvolvimento nos últimos anos. O termo Ecotoxicologia foi utilizado inicialmente por TRUHART (1969) apud MORIARTY (1983), e pode ser definido como a ciência que estuda os efeitos de poluentes em nível individual e suas conseqüências na estrutura e funcionamento das populações, comunidades e ecossistemas (SOARES, 1990).

A integridade biótica de um sistema ecológico é sempre demonstrada pela saúde dos indivíduos que nele residem (ADAMS et al., 1993). Logo, as populações e comunidades são consideradas indicadoras do nível de contaminação ambiental, onde a presença ou ausência, de determinadas espécies, pode ser um indicativo da modificação do ecossistema. Desta forma, selecionam-se determinadas espécies, para que suas respostas fisiológicas e comportamentais sejam estudadas e relacionadas com a exposição direta dos organismos aos poluentes (CHAPMAN, 1989).

Segundo o tempo de exposição, o critério a ser adotado e os organismos testados, caracteriza-se 0 teste a ser empregado (RAND \& PETROCELLI, 1985). Podem ainda, ser aplicados para avaliar a toxicidade de uma amostra: teste para avaliação da toxicidade aguda e teste para avaliação da toxicidade crônica que, geralmente, são feitos com três tipos de organismos, que pertencem a diferentes níveis tróficos do ambiente aquático. 
De acordo com a composição química de algumas substâncias que são tóxicas apenas aos peixes, outras somente a microcrustáceos e às vezes a ambos; assim, é aconselhável avaliar os efeitos de agentes tóxicos a mais de uma espécie representativa da biota aquática, para que se possa através do resultado obtido com o organismo mais sensível estimar com maior segurança o impacto dessas substâncias em um sistema receptor (CETESB, 1990).

\subsection{Natureza da Poluição}

São conhecidas cerca de onze milhões de substâncias químicas e apenas uma pequena porcentagem está bem estudada em relação aos seus efeitos e dinâmica no meio ambiente (MANNIING \& TIEDMANN, 1995).

Segundo SELL (1992), independente de sua origem ou natureza, os poluentes presentes em ecossistemas aquáticos podem ser agrupados em três categorias principais, de acordo com a sua distribuição no meio ambiente:

- Material flutuante (óleos e graxas), eles retardam o crescimento das plantas aquáticas pelo bloqueio da luz solar, interferem na re-aeração natural, destruindo a vegetação e a população de aves aquáticas, além de serem muitas vezes, inflamáveis.

- Material em suspensão, que pode ser de origem mineral ou orgânica. O mineral é responsável pela formação do lodo, que asfixia a população bacteriana aeróbia e compromete os sedimentos. O material de origem orgânica é o responsável pela diminuição dos níveis de oxigênio dissolvido e pela formação de gases e odores desagradáveis.

- Material em solução, representado pelos ácidos, álcalis, metais-traço e compostos xenobióticos. De um modo geral, eles destroem a vida aquática e tornam a água imprópria, exigindo tratamentos sofisticados para que esta água seja utilizada para consumo humano. 
Os mecanismos que determinam a distribuição dos contaminantes nos diferentes compartimentos do ecossistema, coluna de água, matéria em suspensão ou sedimentos dependem das condições de descarga, isto é da concentração e tipo do poluente, das suas propriedades físicas e químicas, das reações e interações entre eles e, os fatores bióticos e abióticos do meio. A solubilidade, influenciada pelo $\mathrm{pH}$ e temperatura, a constante de dissociação, a volatilização, a dissipação e a capacidade de lixiviação são as características que mais interferem na distribuição dos poluentes no meio ambiente (COELHO, 2001).

Os principais problemas da poluição industrial estão relacionados principalmente com valores elevados de matéria orgânica expressa na forma de DBO (Demanda Bioquímica de Oxigênio), deposição ácida, acúmulo de substâncias tóxicas e alta concentração de sólidos em suspensão (SELL, 1992; LAWS, 1993).

Segundo WESTMAN (1985), substâncias tóxicas como os metais pesados, compostos orgânicos sintéticos e radionuclídeos apresentam algumas semelhanças em relação ao ciclo biogeoquímico no meio aquático, concentram-se nos sedimentos, nas manchas de óleo e no tecido gorduroso dos carnívoros e nos organismos bentônicos. Deve-se ser levado em consideração que os metais podem ser ressuspendidos dos sedimentos voltando para a coluna de água muito tempo depois do término dos lançamentos.

Atualmente há uma grande preocupação da comunidade cientifica a respeito dos fluidos industriais de usinagem, pois existe um aumento constante do volume de rejeito de tais substâncias. 


\subsection{Fluidos Industriais de Usinagem}

De acordo com EISENTRAEGER et al (2002), 32\% de todo óleo lubrificante utilizado nos Estados Unidos, são dispostos no ambiente, dos quais, grande parte sem qualquer conhecimento de suas propriedades ou sua aparência. Estes óleos são geralmente usados em processos de lubrificação (Figura 1.1), tanto para sistemas hidráulicos, quanto para processos em que ocorre friç̧ão (retificação, fresamento, etc). Adicionalmente, muito destes fluídos atingem os corpos d'água em decorrência de vazamentos de frascos, como também pela lavagem de filtros utilizados nas máquinas. Por estas razões, é importante que sejam feitos estudos de disposição e biodegradabilidade e toxicidade dessas substâncias.

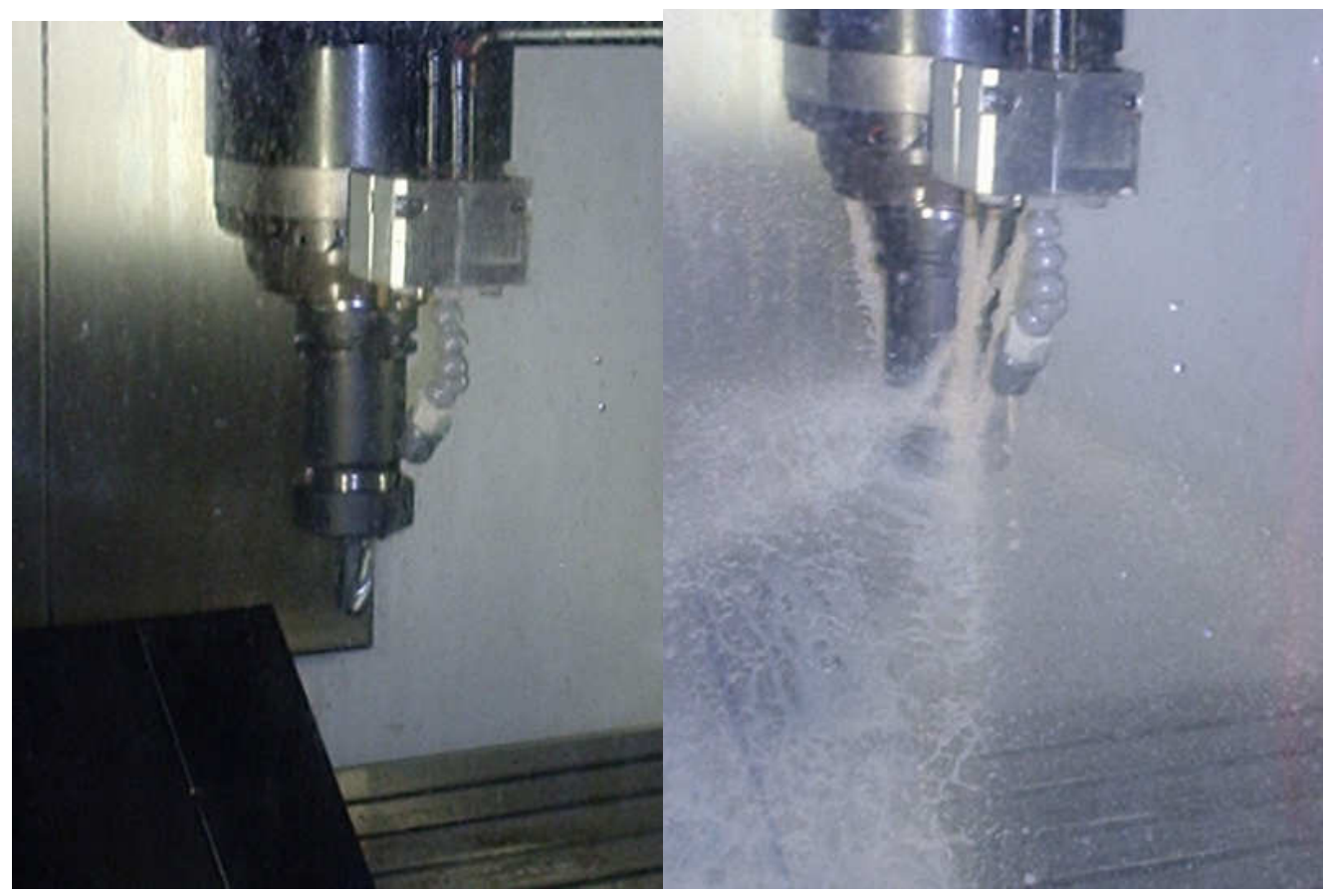
metálicas.

Figura 1.1 - Fotografia de sistema empregando fluido de usinagem de peças

No Brasil, os estudos sobre fluidos de usinagem são bastante incipientes, tendo sido iniciados pelo grupo de Química Analítica Aplicada a Medicamentos e a Ecossistemas Aquáticos e Terrestres, Instituto de Química de São Carlos, Universidade de São Paulo. Embora exista legislação brasileira 
que regulamente a utilização e devolução destes óleos após o uso para seus fabricantes, tem-se observado que alguns usuários descartam estes efluentes diretamente no sistema de esgoto, sem que haja qualquer tratamento adequado às substâncias que os compõem (Figura 1.2).

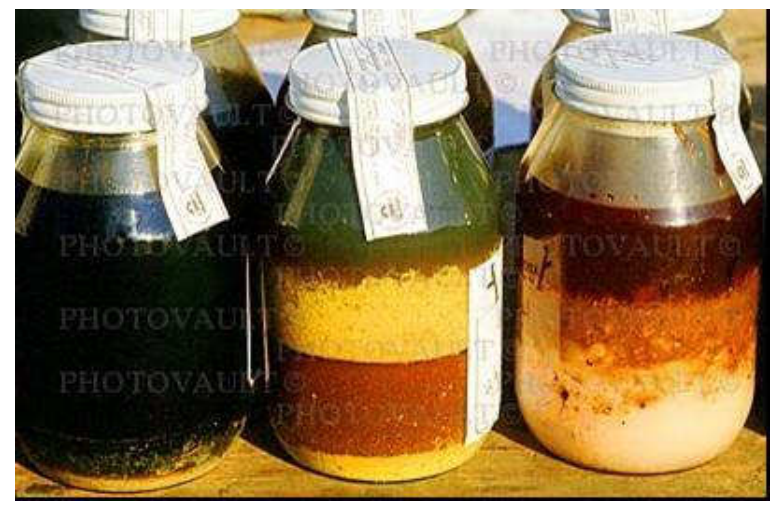

Figura 1. 2 - Material usado que normalmente se descarta indiscriminadamente.

Geralmente, as propriedades físicas e químicas dos fluidos são modificadas durante o seu uso, armazenamento por longos períodos, ou sob ação de alguns microrganismos, sendo, portanto de grande importância o estudo de sua dinâmica nos ambientes naturais (BHATTACHARYYA, 2003). 


\section{CONSIDERAÇÕES TEÓRICAS}

\subsection{Efeitos dos poluentes e o Monitoramento ambiental}

Durante muitas décadas o homem produziu além de bens de consumo, inúmeros poluentes que acabam, de uma forma ou outra, atingindo ao meio ambiente. Com a revolução industrial,aumentou a pressão sobre os recursos naturais, e a sociedade passou a cobrar dos governantes e indústrias uma maior responsabilidade para com os seres que habitam o Planeta. Surge, então, o processo de monitoramento ambiental.

Em relação aos recursos hídricos, o monitoramento ambiental auxilia no gerenciamento, fornecendo informações a respeito da extensão dos impactos causados pela poluição, visando reduzir os efeitos destes impactos (CHAPMAN, 1989). Desta forma, no controle da poluição, é preciso conhecer os processos biológicos e as conseqüências para a saúde pública, assim como, oferecer subsídios para especialistas de outras áreas, tais como químicos, engenheiros, administradores e legisladores, que dividem a responsabilidade do manejo dos recursos hídricos. Neste sentido, o auxílio de outras áreas da ciência, como a ecotoxicologia são de grande importância e necessárias.

Em 1995, ADAMS define a toxicologia aquática como o estudo dos efeitos tóxicos nos organismos aquáticos. Esta ampla definição inclui o estudo dos efeitos tóxicos nos níveis celular (bioquímico e fisiológico), individual, populacional, de comunidade e ecossistema. Mais tarde os ensaios incluíram 
pesquisas básicas para definir e identificar a biologia e a morfologia de lagos e rios, e observam como plantas, animais, e microrganismos interagem para tratar biologicamente o esgoto e reduzir a poluição orgânica. Com isso chegouse a conclusão de que a presença ou a ausência de espécies, vivendo em um dado ecossistema aquático, representa um indicador mais sensível e confiável das condições ambientais que a medida dos parâmetros físicos e químicos.

Ainda, segundo ADAMS (1993), na década de 40 os biólogos advertiram para o fato de que as análises químicas poderiam não medir a toxicidade, mas apenas predizê-la. Os testes de toxicidade realizados nesta mesma época consistiam em expor um limitado número de espécies a substâncias químicas ou efluentes por um curto período de tempo. Estes testes duravam de poucos minutos a várias horas, ocasionalmente se estendiam por dois ou quatro dias, e não seguiam procedimentos padronizados. Atualmente, existem métodos padronizados de testes de toxicidade para inúmeras espécies marinhas e de água doce, planctônicas ou bentônicas, incluindo peixes, invertebrados e algas. Estes testes podem ser utilizados, no controle da qualidade da água dos sistemas receptores, quanto à presença de substâncias tóxicas. O que interessa neste tipo de experimento, segundo BRANCO (1986), é verificar se a água é tóxica, através dos ensaios, e não somente a determinação da presença de substâncias químicas.

Nesse âmbito, segundo BURTON (1994), o monitoramento e o estabelecimento de critérios para a avaliação da qualidade das águas não podem se basear unicamente em métodos químicos, pois:

a) Determinados agentes químicos são capazes de produzir efeitos biológicos contrários em concentrações abaixo dos limites detectados pelos atuais métodos analíticos;

b) Como as análises químicas revelam somente a presença das substâncias nas quais estão possíveis poluentes, alguns compostos podem passar despercebidos; 
c) Em ambientes aquáticos as substâncias químicas não ocorrem em concentrações constantes. Portanto, um monitoramento químico mesmo que regular pode não ser a maneira mais adequada na avaliação de picos ocasionais de concentrações elevadas, as quais são logicamente muito mais danosas ao sistema;

d) Misturas complexas de substâncias químicas, como as que ocorrem nas águas residuárias, tornam a análise da toxicidade complexa, pois não se pode determinar se esta é causada por um ou vários componentes desta amostra. Logo, determinados efeitos antagônicos e sinérgicos, podem tornar a toxicidade maior, menor, ou até mesmo igualar a soma da toxicidade dos seus constituintes;

e) Análises físicas e químicas são pontuais no tempo, enquanto que os testes de toxicidade também avaliam, não só o estado no momento da amostragem, mas também as condições pré-existentes.

\subsection{Poluição Orgânica}

Dentre muitas fontes deste tipo de poluição, destacam-se os efluentes domésticos, industriais e agrícolas. O potencial poluidor de um efluente orgânico é freqüentemente expresso em termos de sua demanda bioquímica de oxigênio (DBO) (ABEL, 1998), que, de acordo com RICHTER (1998), pode ser definida como "a quantidade de oxigênio necessária para a respiração dos microrganismos responsáveis pela estabilização (oxidação) da matéria orgânica, através da sua atividade metabólica em meio aeróbio, num certo tempo em uma determinada temperatura".

Em águas não poluídas, a quantidade relativamente pequena de matéria orgânica em decomposição é prontamente assimilada pela fauna e flora. Uma 
parte é consumida por animais detritívoros e incorporada à biomassa. $\mathrm{O}$ restante é decomposto por bactérias e fungos, que por sua vez, servem de alimento para organismos de níveis tróficos mais elevados.

A atividade dos microrganismos resulta, geralmente na "quebra" de moléculas orgânicas complexas em substâncias inorgânicas, tais como íons nitrato e fosfato, que se tornam nutrientes disponíveis para os produtores. Neste processo metabólico, consome-se oxigênio. Porém, quando a taxa deste consumo excede a taxa de aeração, diminui a concentração desse gás dissolvido na água, tornando-o insuficiente para a manutenção de algumas espécies, que podem ou não ser substituídas por outras com demanda de oxigênio menor (BURTON, 1994).

\subsubsection{Componentes Orgânicos e Toxicidade}

Em águas residuárias, chama-se de material orgânico toda substância orgânica presente em uma amostra. Tal termo vem dos problemas causados pela grande quantidade de substâncias diferentes que compõem os resíduos domésticos e industriais.

Todo material orgânico pode ser oxidado. Desta forma, desenvolveramse duas análises amplamente utilizadas na quantificação de tal material, a Demanda Química de Oxigênio (DQO) e a Demanda Bioquímica de Oxigênio (DBO), ambas com procedimentos padronizados e conhecidos em todo 0 mundo. Em ambos os testes a concentração de material orgânico é calculada a partir do consumo de uma substância oxidante, normalmente uma mistura de ácido sulfúrico e dicromato de potássio, prata e mercúrio para o teste da DQO (BORRELY, 2001).

Para a DBO, utiliza-se o oxigênio e a degradação do material orgânico é realizada em grande parte por bactérias. Embora estas análises não possam 
dizer exatamente qual a concentração de carbono orgânico presente, há um indício da presença deste material, obtido em procedimento padrão que favorece a comparação com dados obtidos em qualquer lugar no mundo (APHA, 1995).

Como já descrito anteriormente, análises deste tipo não apresentam a totalidade de informações necessárias para avaliação de um corpo aquático. Dessa forma, podemos concluir que existe certo controle para a emissão de efluentes prevista em legislação, contudo, em virtude da grande quantidade de substâncias passíveis de serem lançadas nos ambientes aquáticos pelas atividades humanas, verifica-se que 0 número para os quais foram estabelecidos os padrões está muito distante aos que seriam necessários para um controle efetivo, sem considerar que a tecnologia envolvida para isso seria tal, que seus custos inviabilizariam qualquer tentativa em usá-la.

Por outro lado, a legislação brasileira (D.O.U., 2005) estabelece a concentração de poluentes que pode ser aceita em efluentes. Este índice pode não ser adequado, pois a junção de alguns tipos de efluentes antes do descarte podem favorecer a redução na concentração. Além disto, alguns elementos ou moléculas podem ser bioacumulados. Assim, a determinação da taxa de aporte dos poluentes poderia indicar mais precisamente o impacto causado pelo referido efluente.

Existem várias situações em que os problemas para detectar e identificar as substâncias tóxicas presentes em efluentes de natureza química complexa são evidentes. Isto impossibilita verificar os efeitos que essas substâncias apresentam sobre a biota aquática isoladamente, pois existem evidências que a atividade biológica dessas substâncias relaciona-se com as interações entre os componentes da mistura (WALSH \& COL. 1980), ou seja, a forma mais adequada de verificar os efeitos que os poluentes causam aos organismos aquáticos é utilizar os mesmos em testes de toxicidade (organismos representativos das comunidades biológicas dos corpos receptores). Além 
disto, condições de estresse, como a presença de predadores, a baixa concentração de nutrientes ou outros fatores, podem agir sinergicamente aumentando a toxicidade de um dado composto ou elemento, levando ao um efeito ambiental maior que o estimado em laboratórios. Assim, novos testes têm sido desenvolvidos de forma a avaliar a toxicidade in situ, de modo a considerar estes outros parâmetros (COELHO, 2001).

Os resíduos de usinagem de peças metálicas são complexos e pouco estudados no sentido de um destino correto desse material.

\subsubsection{Amostras de fluidos de usinagem de peças metálicas (uma mistura complexa).}

Amostras complexas são aquelas em que ocorre uma mistura de diversos componentes, onde muito dos quais representam um risco para a vida aquática e, como conseqüência, aos outros seres vivos (BERGMAN, 1982).

Compostos tóxicos em uma mistura modificam seletivamente a composição da comunidade biológica que a degradaria, alterando a sua atividade. Freqüentemente, a adição de agentes biocidas em misturas de compostos químicos para protegê-los da biodegradação e aumentar a durabilidade dos produtos, torna-os mais persistentes quando liberados para o ambiente, enquanto que, se mantivessem uma composição livre dessas substâncias numa situação normal, poderiam ser mais facilmente biodegradáveis (WALSH \& COL, 1980).

De outra forma, reações entre certos compostos de uma mistura, normalmente, induzem a formação de produtos tóxicos. É possível também, que ocorram interações entre tais constituintes da mistura complexa de forma tal que compostos carcinogênicos e outras substâncias tóxicas sejam produzidas (BAILEY, 2000). 
Ocorrem ainda, entre os componentes de misturas, outras reações de modo a aumentar ou reduzir a taxa de biodegradação. O processo conhecido como co-metabolismo (degradação de um composto resistente facilitada enquanto os microrganismos metabolizam outros compostos) é verificado entre vários hidrocarbonetos aromáticos polinucleados em presença de misturas de petróleo e é um exemplo clássico dentro das análises de amostras complexas.

Em estudo recente, AMARANTE JR. (2003) determinou por Cromatografia Gasosa de Alta Resolução (CGAR), com detector de lonização em Chama (IC) e cromatografia gasosa acoplada a espectrômetro de massas (EM) a composição de sete fluidos de corte comumente empregados nas oficinas de produção de peças metálicas da região de São Carlos, SP (Tabela 2.1).

TABELA 2.1 - Componentes dos fluidos estudados por AMARANTE JR. (2003).

\begin{tabular}{|c|c|c|}
\hline Natureza & Compostos encontrados & $\begin{array}{l}\text { Tamanho das cadeias (átomos } \\
\text { de carbono) }\end{array}$ \\
\hline Vegetal & $\begin{array}{c}\text { Ésteres com alceno cíclico } \\
\text { Ésteres alifáticos } \\
\text { silicones }\end{array}$ & $\begin{array}{l}22 \text { átomos de carbono } \\
20-26 \text { átomos de carbono } \\
\text { Estruturas não determinadas }\end{array}$ \\
\hline Sintético & $\begin{array}{c}\text { Glicol } \\
\text { Aminas terciárias } \\
\text { Ésteres do ácido ftálico } \\
\text { silicones }\end{array}$ & $\begin{array}{l}\text { 3 átomos de carbono } \\
\text { 8- átomos de carbono } \\
12-16 \text { átomos de carbonos } \\
\text { Estruturas não determinadas }\end{array}$ \\
\hline $\begin{array}{l}\text { Semi-sintético } \\
\text { (sintético + } \\
\text { mineral) }\end{array}$ & $\begin{array}{c}\text { N-parafinas } \\
\text { Amida graxa } \\
\text { Álcool com duplas ligações } \\
\text { conjugadas }\end{array}$ & $\begin{array}{l}\text { 10-21 átomos de carbono } \\
16-23 \text { átomos de carbono } \\
8 \text { átomos de carbono }\end{array}$ \\
\hline Sintético & $\begin{array}{c}\text { Hidrocarbonetos insaturados } \\
\text { Silicones }\end{array}$ & $\begin{array}{l}21 \text { átomos de carbono } \\
\text { Estruturas não determinadas }\end{array}$ \\
\hline Sintético & Hidrocarbonetos insaturados & 17 átomos de carbono \\
\hline Mineral & $\begin{array}{c}\text { N-parafinas } \\
\text { Hidrocarbonetos ramificados } \\
\text { Silicones }\end{array}$ & $\begin{array}{l}\text { 15-25 átomos de carbono } \\
\text { Estruturas não determinadas }\end{array}$ \\
\hline Mineral & $\begin{array}{l}\text { Hidrocarbonetos insaturados, } \\
\text { saturados e ramificados. }\end{array}$ & 16-24 átomos de carbono \\
\hline
\end{tabular}

Pôde-se observar a complexidade dos produtos comerciais de acordo com a sua origem, se mineral, vegetal ou sintético, ou de acordo com os aditivos adicionados para aumentar a eficiência do produto ou sua vida de prateleira. Os principais aditivos empregados em fluidos de corte são apresentados na Tabela 2.2. 
TABELA 2.2. Aditivos usados em fluidos de corte (Adaptada da revista de LUBRIFICAÇÃO, 1986).

\begin{tabular}{|c|c|c|c|}
\hline Tipo de aditivo & $\begin{array}{l}\text { Compostos } \\
\text { empregados }\end{array}$ & Propósito & Mecanismo de ação \\
\hline $\begin{array}{l}\text { Antioxidantes ou } \\
\text { inibidores de } \\
\text { oxidação. }\end{array}$ & $\begin{array}{l}\text { Compostos orgânicos } \\
\text { contendo enxofre, } \\
\text { fósforo e nitrogênio, } \\
\text { como aminas, sulfetos } \\
\text { e hidroxissulfetos. }\end{array}$ & $\begin{array}{c}\text { Impedir a corrosão e } \\
\text { a formação de verniz } \\
\text { e borra na superfície } \\
\text { metálica. }\end{array}$ & $\begin{array}{c}\text { Decompõem os } \\
\text { hidróxidos e impedem a } \\
\text { formação de radicais } \\
\text { livres. }\end{array}$ \\
\hline $\begin{array}{l}\text { Preventivos de } \\
\text { corrosão. }\end{array}$ & $\begin{array}{c}\text { Sufonatos, aminas, } \\
\text { óleos graxos e alguns } \\
\text { ácidos graxos, ácidos } \\
\text { de cera oxidada, } \\
\text { fosfatos, derivados de } \\
\text { alguns ácidos graxos. }\end{array}$ & $\begin{array}{l}\text { Evitar a corrosão } \\
\text { durante paralisações } \\
\text { das atividades, } \\
\text { transporte e } \\
\text { armazenamento. }\end{array}$ & $\begin{array}{l}\text { Adsorvem sobre a } \\
\text { superfície ativa tipo polar. } \\
\text { Formam película que } \\
\text { impede o ataque da água } \\
\text { e de ácidos corrosivos. }\end{array}$ \\
\hline $\begin{array}{l}\text { Agentes de } \\
\text { oleosidade, } \\
\text { resistência de } \\
\text { película, extrema } \\
\text { pressão e } \\
\text { antidesgaste. }\end{array}$ & $\begin{array}{l}\text { Compostos orgânicos } \\
\text { contendo cloro, } \\
\text { fósforo e enxofre, } \\
\text { como ceras cloradas, } \\
\text { fosfatos e fosfitos } \\
\text { orgânicos (i.e. } \\
\text { tricresilfosfato e } \\
\text { ditiofosfato de zinco). }\end{array}$ & $\begin{array}{l}\text { Reduzir o atrito, } \\
\text { impedir escoamento } \\
\text { metálico, escoriação } \\
\text { e grimpamento. } \\
\text { Reduz o desgaste. }\end{array}$ & $\begin{array}{l}\text { Forma-se uma película } \\
\text { sobre a superfície } \\
\text { metálica que é menos } \\
\text { resistente ao } \\
\text { cisalhamento que o } \\
\text { metal, reduzindo o atrito. }\end{array}$ \\
\hline Cargas sólidas. & $\begin{array}{l}\text { Grafite, talco, argila, } \\
\text { carbonato de cálcio, } \\
\text { silicato de sódio. }\end{array}$ & $\begin{array}{c}\text { Impedir o } \\
\text { agarramento ou } \\
\text { caldeamento do } \\
\text { metal. } \\
\end{array}$ & $\begin{array}{l}\text { Formam um espaçador } \\
\text { físico que impede o } \\
\text { contato metálico. }\end{array}$ \\
\hline $\begin{array}{l}\text { Passivadores } \\
\text { metálicos. }\end{array}$ & $\begin{array}{l}\text { Compostos contendo } \\
\text { complexos de } \\
\text { nitrogênio e enxofre, } \\
\text { como algumas } \\
\text { aminas e sulfetos } \\
\text { complexos. }\end{array}$ & $\begin{array}{l}\text { Passivar, impedir ou } \\
\text { neutralizar o efeito } \\
\text { catalítico dos metais } \\
\text { na oxidação. }\end{array}$ & $\begin{array}{l}\text { Formam película inativa } \\
\text { por adsorção ou } \\
\text { absorção. Formam } \\
\text { complexos inativos com } \\
\text { os cátions metálicos } \\
\text { solúveis ou insolúveis. }\end{array}$ \\
\hline $\begin{array}{l}\text { Agentes de } \\
\text { elasticidade e } \\
\text { aderência. }\end{array}$ & $\begin{array}{c}\text { Polímeros de elevado } \\
\text { peso molecular e } \\
\text { sabões de alumínio } \\
\text { de ácidos graxos não- } \\
\text { saturados. }\end{array}$ & $\begin{array}{c}\text { Aumentar } \\
\text { adesividade do } \\
\text { lubrificante formando } \\
\text { uma película } \\
\text { protetora. }\end{array}$ & $\begin{array}{c}\text { Aumenta a viscosidade } \\
\text { do lubrificante. }\end{array}$ \\
\hline Emulsificantes. & $\begin{array}{c}\text { Sabões de gorduras e } \\
\text { ácidos graxos, ácidos } \\
\text { sulfônicos ou ácidos } \\
\text { naftênicos. }\end{array}$ & $\begin{array}{l}\text { Formar emulsão do } \\
\text { óleo com a água para } \\
\text { uso como refrigerante } \\
\text { e lubrificante. }\end{array}$ & $\begin{array}{c}\text { Reduzem a tensão } \\
\text { superficial, de forma que } \\
\text { o óleo possa ser disperso } \\
\text { na água. }\end{array}$ \\
\hline $\begin{array}{l}\text { Bactericidas ou } \\
\text { desinfetantes. }\end{array}$ & $\begin{array}{c}\text { Álcoois, aminas, } \\
\text { aldeídos, fenóis e } \\
\text { compostos contendo } \\
\text { cloro. }\end{array}$ & $\begin{array}{c}\text { Controlar a } \\
\text { degradação de } \\
\text { matéria orgânica com } \\
\text { conseqüente } \\
\text { formação de odor, } \\
\text { manchas nos metais } \\
\text { e quebra de emulsão. }\end{array}$ & $\begin{array}{c}\text { Reduzem a atividade } \\
\text { bacteriana. }\end{array}$ \\
\hline $\begin{array}{l}\text { Inibidores de } \\
\text { espuma. }\end{array}$ & Polímeros de silicone. & $\begin{array}{l}\text { Impedir a formação } \\
\text { de espuma estável. }\end{array}$ & $\begin{array}{c}\text { Reduzem a tensão } \\
\text { interfacial,permitindo o } \\
\text { agrupamento de } \\
\text { pequenas bolhas de ar, } \\
\text { formando bolhas grandes } \\
\text { que se separam. }\end{array}$ \\
\hline
\end{tabular}




\subsection{O Despejo de Fluidos no Ambiente e sua Dinâmica}

Óleos lubrificantes, geralmente, são produtos que apresentam uma grande variação na sua composição. Normalmente são misturas que possuem desde compostos com estruturas bastante simples, como alguns alcanos, até compostos mais complexos como os asfaltenos (ROQUES et al, 1994; RAO, 2002). Tais produtos existem sob várias formas podendo ser de origem mineral, vegetal sintética ou semi-sintética. Dentre os fluidos encontrados no mercado, tem-se uma grande preocupação quanto à constituição dos óleos minerais. Isto se deve ao fato de apresentarem riscos potenciais ao ambiente e à saúde humana. A exposição direta de trabalhadores aos óleos minerais pode causar alergias, doenças de pele, respiratórias e aumento na incidência de alguns tipos de câncer (TOLBERT et al, 1992; SCHROEEDER, et al, 1997; YOUNG et al., 1997). A correta identificação dos constituintes dos produtos de petróleo em um derramamento, por exemplo, e a sua fonte são informações importantes para a resolução de conflitos ambientais, uma vez que define a fonte da poluição e, conseqüentemente, a responsabilidade legal (WANG et al, 1999). Entretanto, outros fluidos também podem apresentar efeito tóxico, sendo necessário o entendimento dos impactos causados por estes, quando atingem os compartimentos ambientais.

Atualmente, as indústrias extraem inúmeros produtos de uma única fonte, o petróleo. Combustíveis e lubrificantes são de especial relevância para a humanidade e por isso sua produção ocorre em uma escala gigantesca. De acordo com Óleo Lubrificante Usado (ON LINE, 2001) a produção anual está entre 250.000 e $300.000 \mathrm{~m}^{3}$ apenas de lubrificantes, dos quais, após o uso, não se sabe ao certo qual o seu destino, podendo ser jogados de forma criminosa no solo e, por conseqüência, em corpos aquáticos. Um exemplo prático para vislumbrar o efeito destes poluentes é verificar que apenas um litro de óleo derramado sobre a água, produz uma película muito fina (com micrômetros de espessura) e esta pode cobrir até uma área de $1.000 \mathrm{~m}^{2}$. Este 
filme funciona como uma barreira física impedindo as trocas gasosas (impedindo a oxigenação), diminuindo a entrada de luz solar (reduzindo a zona eufótica) e, em conseqüência, impedindo o desenvolvimento de qualquer organismo aquático. Como sugestão para sua eliminação, já foi proposta a sua incineração, contudo, verificou-se que tal processo não resolveria o problema uma vez que lança para no ar metais pesados e dioxinas (potencialmente cancerígenos), além de outros subprodutos que atingiriam os corpos d'água da mesma forma (ÓLEO LUBRIFICANTE USADO, ON LINE, 2001; AMARANTE JR. et al, 2003). Desta forma, cria-se à necessidade de processos mais eficientes e de baixo custo que dêem a estes resíduos um destino mais seguro em termos ambientais.

O destino e dinâmica desses poluentes são dependentes de diversos fatores (biológicos, químicos, físicos), tais como evaporação, biodegradação, foto-oxidação, adsorção e dessorção, entre outros. Tal combinação leva ao "envelhecimento" ou degradação do poluente e é responsável pela redução da concentração dos seus constituintes nos diversos compartimentos, sejam os solos, as águas ou os sedimentos. Essas mudanças ocorridas nos fluidos derramados têm um efeito pronunciado na toxicidade e nos impactos causados ao longo do tempo (WANG et al, 1999).

\subsubsection{Contaminação do Meio}

O transporte de produtos pelo mundo é a principal fonte de divisas dos países capitalistas. Sua importância é tamanha que $90 \%$ de tudo o que é produzido tem seu transporte por navios. Desta forma, o desenvolvimento de barcos que suportam uma carga maior torna-se necessário na expansão dos lucros. Obviamente, quanto maiores são estas máquinas, mais poluição as mesmas tendem a produzir, normalmente ou em acidentes. Atividades de transporte deste tipo produzem acidentes com petroleiros e até mesmo despejos de água de lastro, que correspondem a $23,5 \%$ da entrada de 
compostos tóxicos no ambiente marinho. Outras atividades que envolvem exploração e refino de petróleo, tais como: refinarias costeiras, explorações em plataformas, terminais portuários, entre outras representam $7,6 \%$ do aporte total, descargas urbanas e industriais, bem como a lixiviação e carreamento dos óleos depositados ou descartados em solos e estradas (45,6\%) (CLARK apud FERNANDES, 2001). Além disso, fontes naturais, como a lixiviação de rochas (erosão no fundo do mar) também produz poluentes (10,6\%). Estima-se que entre nove milhões de toneladas de hidrocarbonetos de petróleo entrem no ambiente marinho anualmente, afetando tanto o mar quanto os estuários (FERNANDES, 2001; GREER et al, 2003).

O aporte de óleos em solo ou águas continentais pode se dar por derramamentos acidentais ou criminosos, como a disposição ilegal de óleo usado, por exemplo. Também através da precipitação úmida (chuva, neblina, neve, etc) ou seca (poeira) após terem sido volatilizados e transportados até mesmo por longas distâncias; por problemas no armazenamento, transporte ou manuseio; entre outros. Devido à grande quantidade de hidrocarbonetos e de outros compostos que é disposta anualmente no ambiente, seus efeitos tóxicos e suas diversas características (NASH et al, 1996), faz-se necessário estudar sua dinâmica e destino final.

\subsubsection{Dinâmica e Destino}

Dependendo de sua composição, os óleos podem apresentar diferentes efeitos quando descartados no ambiente. Este processo é representado de forma geral na Figura 2.1. A contaminação pode se apresentar de forma diversificada de acordo com o tipo de solo, os parâmetros climáticos, a origem do petróleo, a composição da mistura, o grau de processamento (se o óleo é considerado cru, misturado ou refinado), a biodiversidade microbiana e a presença de invertebrados no solo, e a degradabilidade quando exposto ao ambiente (AMARANTE JR. et al, 2003). É importante ressaltar que, embora a 
maior concentração de hidrocarbonetos encontrada no ambiente atualmente seja proveniente de atividades humanas, existe uma produção natural de tais compostos por alguns organismos, como em sedimentos anóxicos (MORASCH et al., 2001). Os hidrocarbonetos alifáticos são menos persistentes que os aromáticos, sendo mais prontamente degradados por ação de elementos físicos, químicos e biológicos (KRAHN et al, 1993).

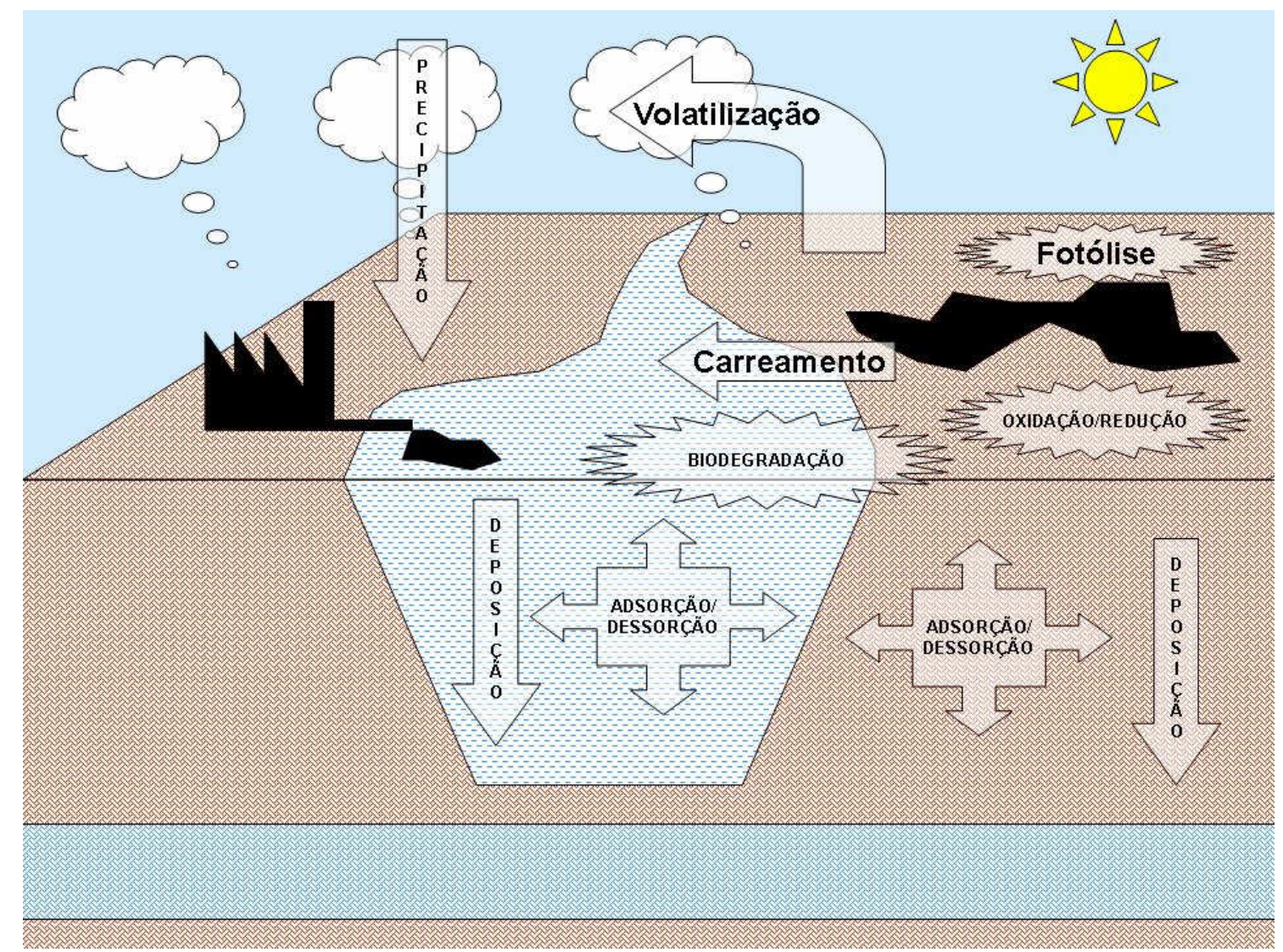

FIGURA 2.1. Dinâmica dos óleos no ambiente (adaptada de TRETT, 1989 apud AMARANTE JR, 2003).

Os óleos presentes na água podem ocasionar diversos efeitos indesejáveis, dos quais se pode destacar a formação de filmes sobre a superfície da água, que pode diminuir a penetração da luz, a concentração de oxigênio dissolvido, entre outras. Outros problemas causados pelos hidrocarbonetos podem ser destacados: o risco de incêndio e explosão, dependendo da quantidade de vapor produzida e do seu confinamento; a 
toxicidade dos componentes, problemas de modificação das características organolépticas da água, como mudanças de cor, odor e sabor, as mudanças nas características do solo, interferindo na retenção e permeação de água e, conseqüentemente, no transporte de nutrientes, entre outros. Cabe ressaltar que compostos mais leves (menor massa molar) apresentam geralmente certa volatilidade, podendo ser transportados por vias aéreas a grandes distâncias, enquanto compostos mais pesados (maior massa molar) e com cadeias mais ramificadas persistem por mais tempo no ambiente (PADRÕES NACIONAIS CANADENSES, ON LINE, 2001). Por outro lado, compostos com cadeia carbônica pequena apresentam maior toxicidade por serem prontamente transferidos para o interior das células, enquanto compostos de cadeia longa permanecem no exterior da célula, apresentando menor potencial tóxico (AMARANTE JR., 2003).

Observa-se que, uma vez no solo, estes compostos podem ser adsorvidos, principalmente pela fração argilosa, a qual apresenta menor granulometria e grande quantidade de matéria orgânica. Os componentes orgânicos do solo, em especial as substâncias húmicas, têm sido relatados como bons adsorvestes de compostos hidrofóbicos (ARAÚJO et al, 2004). Compostos adsorvidos podem apresentar menor biodisponibilidade e não serem degradados por via biológica (GRAY et al, 2000). Apesar da adsorção destes compostos no solo, parâmetros climáticos ou a baixa concentração de matéria orgânica no solo pode favorecer a dessorção, e conseqüente lixiviação, e carreamento destes óleos, transportando-os através dos diferentes horizontes do solo, atingindo os lençóis subterrâneos ou os rios e lagos. A contaminação de águas superficiais ou de lençóis subterrâneos é um grave problema devido à toxicidade destes compostos (LANGWALDT \& PUHAKKA, 2000). O Benzeno, Tolueno, Etilbenzeno, Xileno (BTEX) e hidrocarbonetos poliaromáticos (HPA) têm sido reportados como contaminantes de águas subterrâneas (MORASCH et al., 2001). 
Nas águas subterrâneas a degradação ocorre mais lentamente devido à ausência de oxigênio e, por vezes, de organismos capazes de metabolizar os constituintes do óleo. É requerida a presença de microrganismos anaeróbios que empreguem os hidrocarbonetos como fonte de carbono e energia e que utilizem compostos inorgânicos (nitratos, por exemplo) e cátions (como Fe3+) como aceptores de elétrons (MORASCH et al, 2001). Para as águas superficiais é possível se observar processos de transporte, associados ao sedimento ou na forma de emulsões, produzidas pelo incremento de energia que ocorre com o movimento das águas (ROBOTHAN \& GILL, 1989). É possível observar, ainda, a dissolução principalmente para hidrocarbonetos de baixa massa molar. Entretanto, a adsorção aos sedimentos em locais com grande taxa de deposição deste material pode transportar os hidrocarbonetos para o leito do corpo aquático, mantendo-o retido até que fatores físicos, químicos ou biológicos, ou ainda a combinação destes, promova a sua dessorção e disponibilização para a coluna d'água (FERNANDES, 2001), afetando, mais prontamente, organismos bentônicos.

A biodegradação pode ser observada por ação de organismos vegetais: a fitorremediação. Embora este processo seja de extrema importância, para investigações a longo prazo um elemento comprometedor é a sucessão ecológica e as modificações que ela implica. No caso de brejos, o potencial de degradação é algo complexo, pois depende de condições variáveis, como hidrologia, tipos de solo e sedimento, diversidade de espécies vegetais, crescimento sazonal e química aquática (WILLIAMS, 2002). Microrganismos como as cianobactérias, organismos fotoautotróficos, podem ser empregados para a biodegradação de poluentes de forma similar à fitorremediação (O’NIELL et al., 1999).

Tanto nos solos quanto nas águas superficiais observam-se processos de descontaminação que podem ser promovidos por fatores físicos, como: temperatura e irradiação luminosa; químicos: processos oxidativos ou redutivos, hidrólise, entre outros; ou biológicos: metabolismo. Elevadas 
temperaturas podem favorecer os processos de volatilização, que transferem os constituintes mais voláteis dos óleos para a atmosfera, sendo possível o transporte por longas distâncias por meio das correntes aéreas. Isto pode favorecer a deposição destes poluentes através de precipitações úmidas (chuva, neve e granizo) ou seca (poeira e fuligem) mesmo em áreas distantes da fonte poluidora. A grande incidência de luz solar promove este efeito devido ao aumento da temperatura, mas promove, também, a fotólise, transformando os constituintes em substâncias mais polares pela adição de oxigênio na molécula, aumentando sua hidrossolubilidade $e$, portanto, sua biodegradabilidade (GREEN \& TRETT, 1989; FERNANDES, 2001).

Em estudo com água do mar próxima a plataformas, na Austrália, BURNS \& CODI (1999) estudaram a dinâmica de hidrocarbonetos não-voláteis, percebendo uma dissipação governada, principalmente, devido à diluição ocasionada pelas correntes marinhas. A degradação seria o segundo fator, em termos de relevância, para a dissipação destes compostos, seguida pela sedimentação e, depois, pela evaporação. Neste estudo, os autores observaram o elevado grau de bioacumulação de tais substâncias nos tecidos de bivalves, além da dessorção dos hidrocarbonetos proveniente de partículas em suspensão em um raio de até $1,8 \mathrm{~km}$ a partir da fonte poluidora, mostrando o potencial de transporte de tais compostos associados ao sedimento e ao material particulado.

O derramamento de óleos pode provocar a formação de filmes sobre a superfície da água de modo a impedir a oxigenação (troca gasosa), bem como reduzir a entrada de luz, diminuindo a zona eufótica. A baixa oxigenação e a diminuição na fotossíntese podem impedir tanto a autodepuração quanto o funcionamento normal do ecossistema aquático, atingido diversos organismos (GREEN \& TRETT, 1989; ROBOTHAM \& GILL, 1989; FERNANDES, 2001). Desta forma, ocorre mudança no $\mathrm{pH}$, principalmente, quando se tem a presença de compostos mais polares que apresentem características ácidas ou alcalinas. Pode ocorrer, ainda, a seleção de espécies que se adaptem melhor à 
presença dos hidrocarbonetos, sendo observado o desaparecimento de diversas espécies do fitoplâncton e do zooplâncton, desenvolvendo-se aquelas latentes pela diminuição da concorrência por recursos (ROBOTHAM \& GILL, 1989).

Compostos aromáticos também apresentam elevada toxicidade. Hidrocarbonetos poli-aromáticos (HPA) são mutagênicos e carcinogênicos, apresentando, ainda, capacidade de se acumularem nos organismos e nos sedimentos (FERNANDES, 2001). O uso de tensoativos, chamados dispersantes, para desfazer as manchas de óleo aumenta a toxicidade dos componentes do óleo uma vez que aumentam a taxa de transferência dos mesmos para a célula.

Para organismos vegetais, a época do derramamento de óleos, por exemplo, pode estar diretamente ligada ao efeito observado. Derramamentos ocorridos no inverno apresentam efeitos inexpressivos uma vez que a atividade da flora se encontra reduzida, embora possam ser observadas perdas na floração na primavera seguinte. Nos períodos de primavera e verão os derramamentos podem apresentar efeitos mais intensos visto que afetam a germinação, crescimento e produção de sementes (FERNANDES, 2001).

Petróleo ou óleo cru é uma mistura de extrema complexidade. Dentre seus inúmeros compostos destacam-se os combustíveis e os lubrificantes, por serem amplamente difundidos nas atividades humanas, como também em decorrência do seu alto valor econômico. Os fluidos de corte ou óleos de corte são amplamente utilizados na indústria, tendo como principal função diminuir o calor gerado durante os processos de produção.

Em decorrência de seu amplo uso, estes compostos acabam, muitas vezes, atingindo os corpos d'água causando obstrução da rede coletora de esgotos, inibição nos processos de tratamento de efluentes, além de um número incalculável de problemas ao meio ambiente (PIVELI, 1998). 
Nas águas naturais, os óleos acumulam-se na superfície (por apresentar menor peso específico), acarretando sérios problemas ecológicos, principalmente, por dificultar as trocas gasosas que ocorrem entre a massa liquida e a atmosfera (Figura 2.2. e 2.3.). Além disso, causam um problema estético quando acumulados em praias e nas margens de rios (PIVELI, 1998).

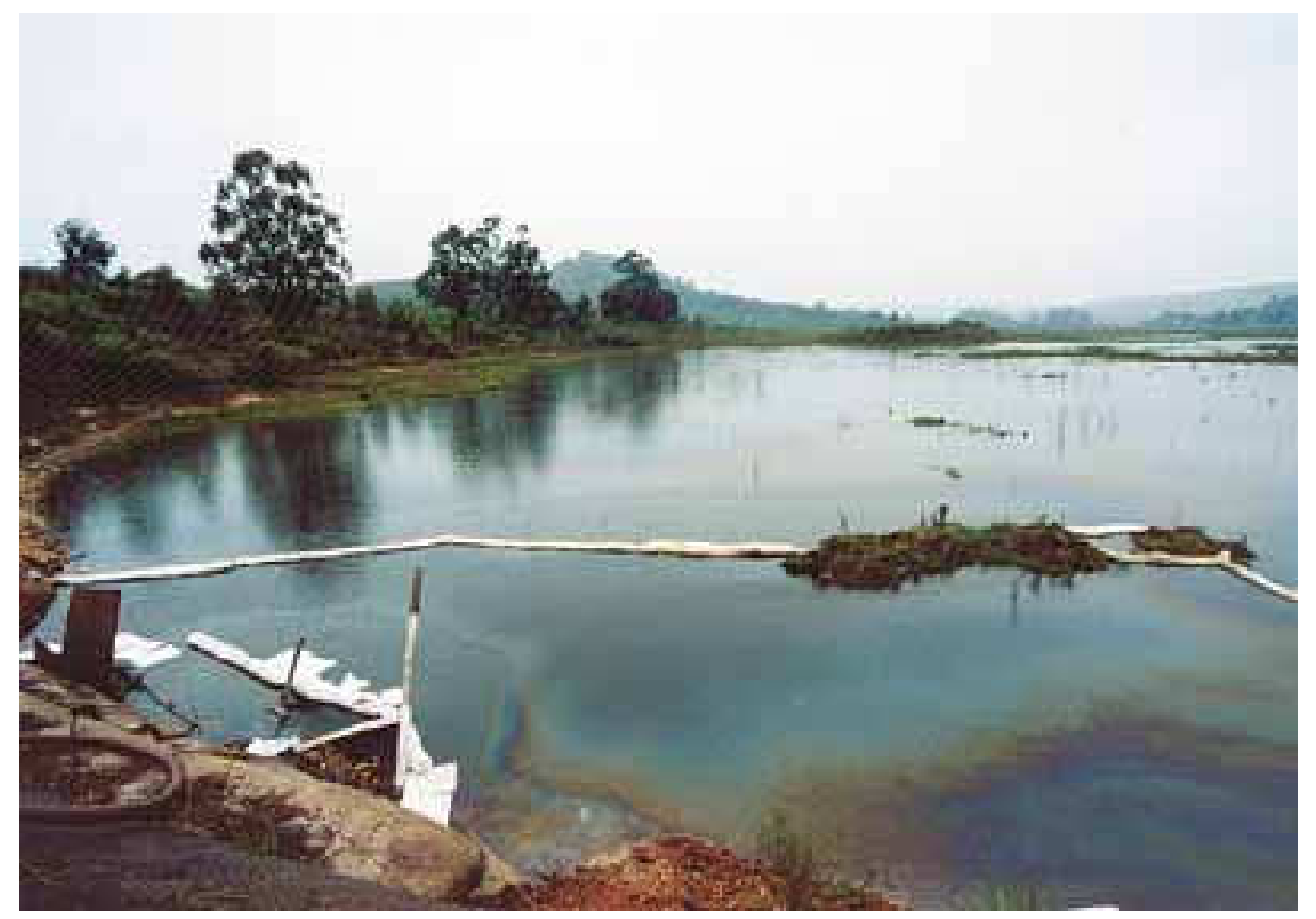

Fonte: Jornal o Estado de São Paulo Figura 2.2 - Derramamento acidental de óleo em corpo d' água. 


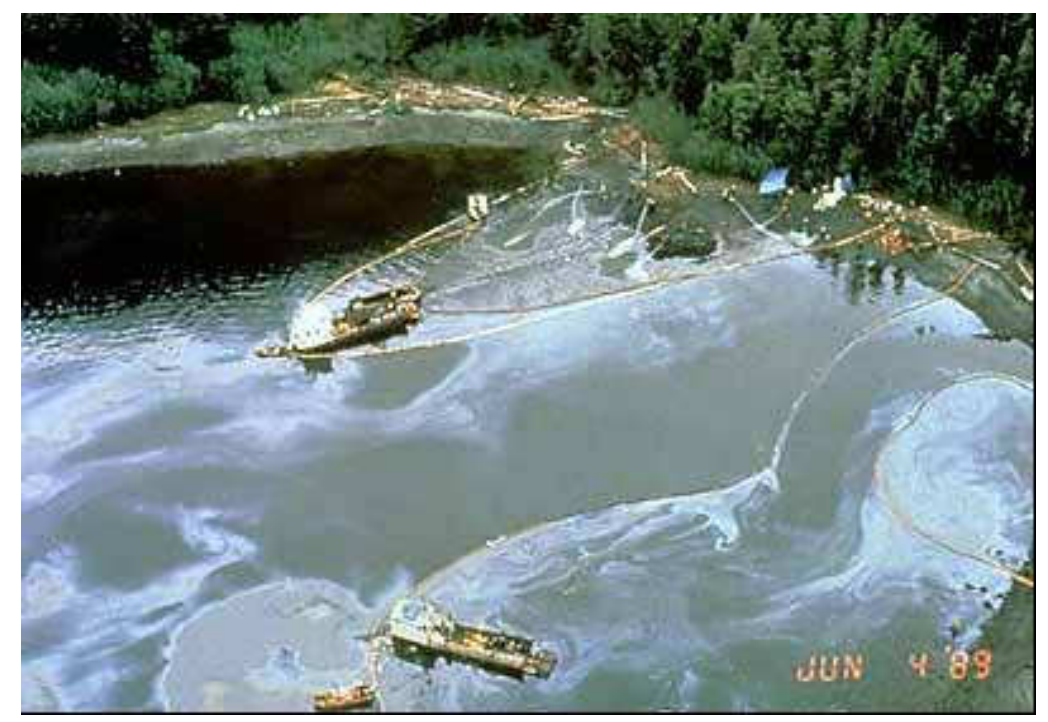

Figura 2.3. - Operação de limpeza do acidente com o navio Exxon Valdez.

Devido a estes acidentes, fazem-se necessários estudos que colaborem para o entendimento da dinâmica ambiental dos constituintes destes produtos, principalmente quando consideramos a ampla utilização de lubrificantes na indústria mecânica para a produção de peças, o que pode levar ao derramamento acidental, ao descarte deliberado, ou falhas no armazenamento que levam à contaminação dos compartimentos ambientais.

Dentre estes estudos, destaca-se a grande falta de informações sobre os efeitos tóxicos dos produtos sobre a biota. 


\subsection{Legislação Aplicável}

De acordo com a Política Nacional do Meio Ambiente, Lei 6938/81, todo aquele que usar economicamente os recursos ambientais deve contribuir pecuniariamente (artigo 4\%, inciso VII). São os chamados princípios "usuáriopagador" e "poluidor-pagador". Na Lei de Crimes Ambientais (Lei №. 9605/98), encontra-se previsão de penas para aqueles que poluem o ambiente, conforme pode ser observado:

"Art. 54 - Causar poluição de qualquer natureza em níveis tais que resultem ou possam resultar em danos à saúde humana, ou que provoquem a mortandade de animais ou a destruição significativa da flora":

Pena - reclusão, de um a quatro anos, e multa.

$\S 1^{\text {o }}$ - Se o crime é culposo:

Pena - detenção, de seis meses a um ano, e multa.

$\S 2^{\circ}$ - Se o crime:

$(\ldots)$

V - ocorrer por lançamento de resíduos sólidos, líquidos ou gasosos, ou detritos, óleos ou substâncias oleosas, em desacordo com as exigências estabelecidas em leis ou regulamentos:

Pena - reclusão, de um a cinco anos.

"Art. 56 - Produzir, processar, embalar, importar, exportar, comprar, fornecer, transportar, armazenar, guardar, ter em depósito ou usar substância tóxica, perigosa ou nociva à saúde humana ou ao meio ambiente em desacordo com as exigências estabelecidas em leis e regulamentos:

Pena- reclusão, de uma a quatro anos, e multa." 


\subsubsection{Resolução CONAMA $09 / 93$}

O Conselho Nacional do Meio Ambiente (CONAMA), através da Resolução de №. 09 (31/08/1993), apresentou uma série de definições sobre óleo lubrificante, reciclagem do óleo lubrificante usado, bem como outros termos, e dispõe que todo lubrificante usado ou contaminado deverá ser recolhido, devendo ter o destino apropriado de modo a evitar impactos negativos ao ambiente. Este recolhimento deve ser efetuado pelo fornecedor do produto, podendo o mesmo realizar novo refino no óleo usado (visto que a reciclagem é considerada prioritária para a gestão deste resíduo). Deste modo, no Brasil, todo óleo usado deverá ser destinado à reciclagem.

Isto foi estabelecido ao considerar que a degradação dos óleos lubrificantes durante o uso é parcial, podendo haver contaminações acidentais ou propositais do ambiente, se os mesmos forem descartados diretamente no ambiente. Isto está baseado na classificação do óleo lubrificante usado como resíduo perigoso, por apresentar toxicidade (ABNT NBR-10004).

Considera-se, ainda, que o descarte de óleos e suas emulsões nos compartimentos ambientais (solos ou águas) pode causar graves problemas ambientais e que a incineração pode gerar gases residuais nocivos (BENTHAM et al., 1997). Deste modo, qualquer outra forma de emprego do óleo usado deve ser previamente autorizada. Esta resolução traz, também, algumas proibições, são elas:

"Art. 3ํㅜㄷam proibidos:

I - quaisquer descartes de óleos usados em solos, águas superficiais, subterrâneas, no mar territorial e em sistemas de esgoto ou evacuação de águas residuais; 
II - qualquer forma de eliminação de óleos usados que provoquem contaminação atmosférica superior ao nível estabelecido na legislação sobre proteção do ar atmosférico (PRONAR);

Art. $4^{\circ}$ Ficam proibidos a industrialização e comercialização de novos óleos lubrificantes não recicláveis, nacionais ou importados."

Antes da disposição final destes resíduos, é necessário, portanto, garantir a eliminação de características tóxicas e poluentes, a preservação dos recursos naturais e 0 atendimento aos padrões de qualidade ambiental. A instalação ou ampliação de empresas que tratem o lubrificante usado deve empregar tecnologias que prevêem a minimização de resíduos a serem lançados no ambiente.

As obrigações dos produtores, geradores, receptores, coletores e rerefinadores são definidas no texto desta Norma Jurídica, que estabelece, ainda, critérios para coleta e transporte dos óleos usados. São exigências: que se adotem medidas para evitar a contaminação do lubrificante com substâncias estranhas ao seu uso e a manutenção de registros sobre compra, uso e alienação do lubrificante usado quando se consumir mais que 700 litros por ano. Ficam de fora desta resolução os óleos biodegradáveis pelos sistemas convencionais de tratamento biológico quando não misturados a óleos usados regeneráveis. Cabe ao IBAMA aprovar o sistema de tratamento e destino final após o uso. 


\subsubsection{Agencia Nacional de Petróleo e suas funções}

A Agência Nacional do Petróleo (ANP) regulamentou, através da Portaria №. 127, de 30 de julho de 1999, a atividade de coleta dos lubrificantes usados, estabelecendo as obrigatoriedades desta atividade. Assim, cabe à ANP expedir o cadastro de coletor para pessoa jurídica sediada no país.

A Portaria №. 129, de 30 de julho de 1999, estabelece o Regulamento Técnico ANP 004/99, que especifica os lubrificantes básicos brasileiros ou importados para comercialização no território nacional. Esta portaria classifica os óleos em parafínicos e naftalênicos, categorizando-os. Estabelece as especificações de qualidade dos lubrificantes básicos comercializados no Brasil, definido quais as características a serem controladas, e define os métodos de análise como sendo as NORMAS BRASILEIRAS REGISTRADAS (NBR) dos métodos da AMERICAN SOCIETY FOR TESTING AND MATERIALS (ASTM) e da Deutsche Norm (DIN), observando-se os de publicação mais recente. Enquanto a Portaria №. 130, de 30 de julho de 1999, estabelece as especificações necessárias à comercialização de óleos lubrificantes básicos re-refinados, com as mesmas constando no Regulamento Técnico ANP №. 005/99, anexo a esta portaria, revogando as resoluções do Conselho Nacional de Petróleo ํo. 16/81 e 13/83, além das demais disposições em contrário.

\subsubsection{Resolução CONAMA 357 (17/03/2005)}

A resolução CONAMA 357, de 17 de março de 2005, que substituiu a resolução 20 de 18 de junho de 1986, estabelece para as águas doces de classe Especial, 1, 2 e 3, que óleos e graxas devem estar virtualmente ausentes, e para águas de classe 4, toleram-se iridescências (cores do arcoíris). Para águas salinas de classes 1 e 2, óleos e graxas devem estar 
virtualmente ausentes, tolerando-se iridescências para águas salinas de classe 3. Para águas salobras de classes 1 e 2, estas substâncias também deverão estar virtualmente ausentes, podendo-se tolerar iridescências para águas de classe 3. Para lançamento de efluentes, é permitido um limite de até $20 \mathrm{mg} \mathrm{L}^{-1}$ para óleos minerais e até $50 \mathrm{mg} \mathrm{L}^{-1}$ para óleos vegetais e gorduras animais. Cabe ainda observar o disposto nesta resolução:

"Art. 43. Os empreendimentos e demais atividades poluidoras que, na data da publicação desta Resolução, tiverem Licença de Instalação ou de Operação, expedida e não impugnada, poderão a critério do órgão ambiental competente, ter prazo de até três anos, contados a partir de sua vigência, para se adequarem às condições e padrões novos ou mais rigorosos previstos nesta Resolução.

§ $1^{\circ} \bigcirc$ empreendedor apresentará ao órgão ambiental competente 0 cronograma das medidas necessárias ao cumprimento do disposto no caput deste artigo.

§ 2으 prazo previsto no caput deste artigo poderá, excepcional e tecnicamente motivado, ser prorrogado por até dois anos, por meio de Termo de Ajustamento de Conduta, ao qual se dará publicidade, enviando-se cópia ao Ministério Público.

§ 3ำ As instalações de tratamento existentes deverão ser mantidas em operação com a capacidade, condições de funcionamento e demais características para as quais foram aprovadas, até que se cumpram as disposições desta Resolução.

§ 4ํO descarte contínuo de água de processo ou de produção em plataformas marítimas de petróleo será objeto de resolução específica, a ser publicada no prazo máximo de um ano, a contar da data de publicação desta Resolução, 
ressalvado o padrão de lançamento de óleos e graxas a ser o definido nos termos do art. 34, desta Resolução, até a edição de resolução específica.".

Para o estudo proposto utilizou-se bioensaios com diferentes organismos aquáticos, além da irradiação das amostras através de feixe de elétrons e avaliação da degradação dos fluidos por microrganismos de presentes em amostras de solo.

\subsection{Descrição dos organismos - teste - Daphnideos.}

Daphnia similis e Daphnia laevis, família Daphnidae, Ordem Cladocera, são organismos planctônicos, filtradores, pequenos (medem de 0,2 a 3,0 mm de comprimento, de forma geral). De acordo (HETERS \& BERNARDI, 1987), os cladóceros morfologicamente, são compostos por uma cabeça e tronco bem definido, os quais se subdividem em tórax, abdômen e pós-abdômen (Figura 2.4).

Possuem também dois pares de antenas, onde o primeiro par é chamado de antênulas, caracterizado por serem pequenas e por possuírem a função de orientação através das cerdas sensitivas. Já o segundo par, é grande, apresenta uma bifurcação e cerdas rígidas, é utilizado para a locomoção. Para se movimentarem as daphnias utilizam-se de pequenos saltos, e por este fato, são popularmente conhecidas como pulgas d’água.

Na cabeça encontram-se também, órgãos sensoriais responsáveis pela orientação na natação do animal, além do cérebro, gânglio e nervos ópticos, músculos antenais e o início do aparelho digestório. O aparelho bucal é composto por mandíbulas, maxílulas, maxilas, lábio e labro (HETERS \& BERNARDI, 1987). 
O corpo dos cladóceros é coberto por uma carapaça quitinosa aberta na região ventral. Na região anterior da carapaça encontra-se um coração oval ou alongado. Os apêndices toráxicos atuam na captura de alimento, pois apresentam cerdas e pêlos que retém pequenas partículas na coluna d'água. $\mathrm{O}$ alimento passa por um canal ventral até a região bucal, através das maxiulas é colocado entre as mandíbulas onde é triturado para digestão.

Finalmente, o pós-abdômen encontra-se curvado para a parte anterior da região ventral. Apresenta garras terminais com espinhos e dentes. Estas garras apresentam a função de limpeza do canal onde se encontra o alimento filtrado (HETERS \& BERNARDI, 1987).

1- Antena;

2- Olho composto;

3- Ceco intestinal;

4- Intestino;

5- Coração;

6- Ocelo;

7- Antênula;

8- $\quad$ Apêndices filtradores
9- Ovário;

10- Furca;

11- Pós abdômen;

12- Câmara incubadora;

13- Carapaça;

14- Cerdas abdominais

15- Espinho.

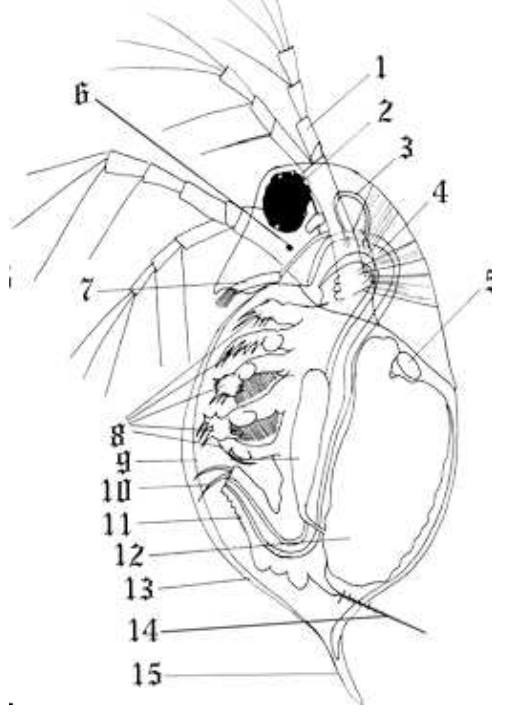

Figura 2.4. Daphnia sp; descrição da morfologia interna e externa.

(Fonte: www.webs.wichita.edu/biology)

Em condições ambientais favoráveis, a reprodução neste grupo de organismo é partenogênica (Figura 2.5). As fêmeas apresentam dois ovários e dois ovidutos que se abrem dorsalmente na câmara incubadora (Figuras 2.4 e 2.6). Saindo do oviduto, os ovos são depositados na cavidade dorsal ou câmara incubadora. 


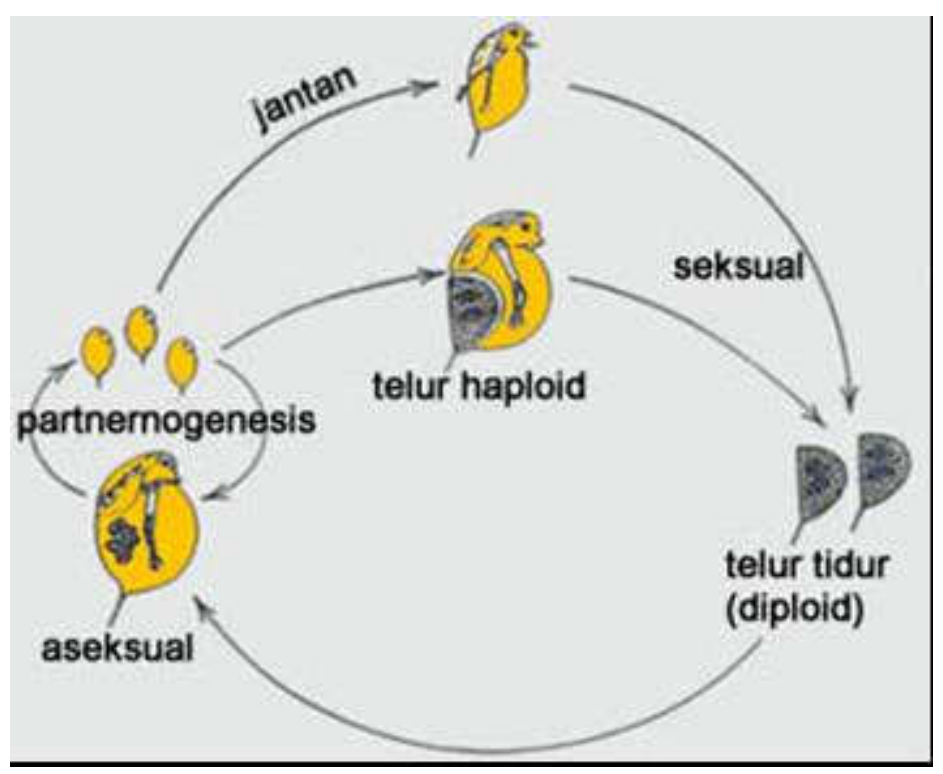

Figura 2.5. - Daphnia sp.; descrição do ciclo de vida.

Por este tipo de reprodução (partenogênica), os filhotes gerados são cópias idênticas as suas mães, inclusive no sexo, ou seja, normalmente somente nascem fêmeas. O nascimento de indivíduos do sexo masculino são raros e isto ocorre com a conversão dos ovos em indivíduos haplóides. Quando os machos estão presentes às fêmeas sofrem reprodução cruzada (Figura 2.6) e dão origem a novos indivíduos denominados efípios, ao quais apresentam cor escura (Figura 2.7) e são capazes de resistir em condições ambientais muito severas.

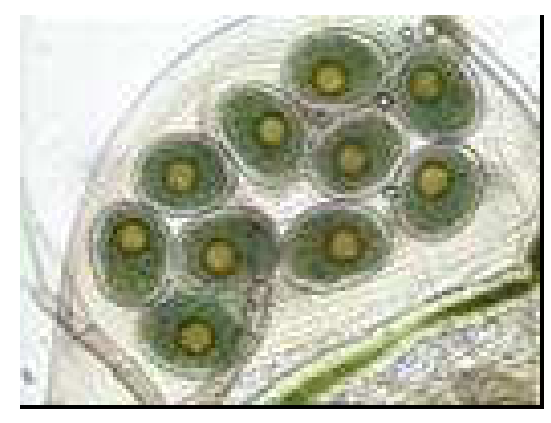

(Fonte: www.fish.com)

Figura 2.6. - Foto de uma câmara de incubação. 
Normalmente, os machos são bem menores que as fêmeas e surgem após várias gerações partenogênicas em decorrência de diversos fatores, como por exemplo, quantidade de alimentos, modificações na temperatura, superpopulação, entre outros. As daphnias realizam a troca de mudas em seu crescimento. Este processo é variável (não existe uniformidade), e sua freqüência e tempo de desenvolvimento são fortemente influenciados pela temperatura.

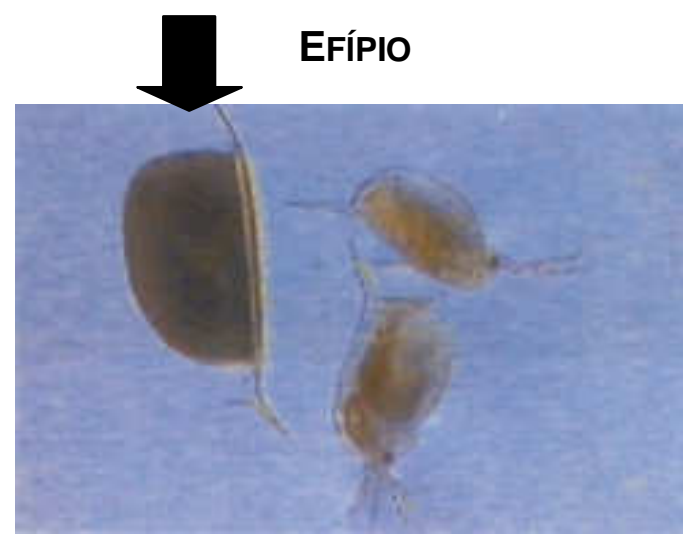

(Fonte: www.biohidricad/ensayo daphtoxkit.htm).

Figura 2.7 - Foto de ovo de resistência (Efípio) de Daphnia sp.

As espécies de cladóceros tradicionalmente utilizadas (Daphnia similis, D. magna, D. pulex e Ceriodaphnia dubia) são escolhidas por sua representatividade ecológica, distribuição e ampla facilidade de cultivo. Devido à natureza filtradora, são excelentes na condensação de fito e bacterioplâncton para sua transferência a outros elos da cadeia trófica, servindo como alimento a larvas de peixes e insetos, crustáceos e peixes.

A cada dia aumenta a preocupação com o destino dos despejos de substâncias poluentes na natureza. Para isso, tecnologias modernas como a irradiação com aceleradores de elétrons são muito estudas, procurando reduzir o impacto na natureza através da degradação de compostos orgânicos presentes nos efluentes domésticos e industriais. 


\subsection{Acelerador de Elétrons: Funcionamento}

Um acelerador de partículas pode ser definido como um equipamento que aplica forças a partículas carregadas por meio de alguma combinação de campos elétricos e magnéticos, gerando íons de alta velocidade e alta energia cinética (Figura 2.8). Quando se estabelece um potencial de alta voltagem entre cátodo e ânodo, no vácuo, o cátodo emite feixe de elétrons, chamados raios catódicos ou feixes de elétrons, seguindo o mesmo princípio do tubo de televisão, onde a diferença fundamental é que este último utiliza 25.000 volts de energia, aproximadamente, enquanto o acelerador utiliza da ordem de bilhões de volts, BLY (1988).

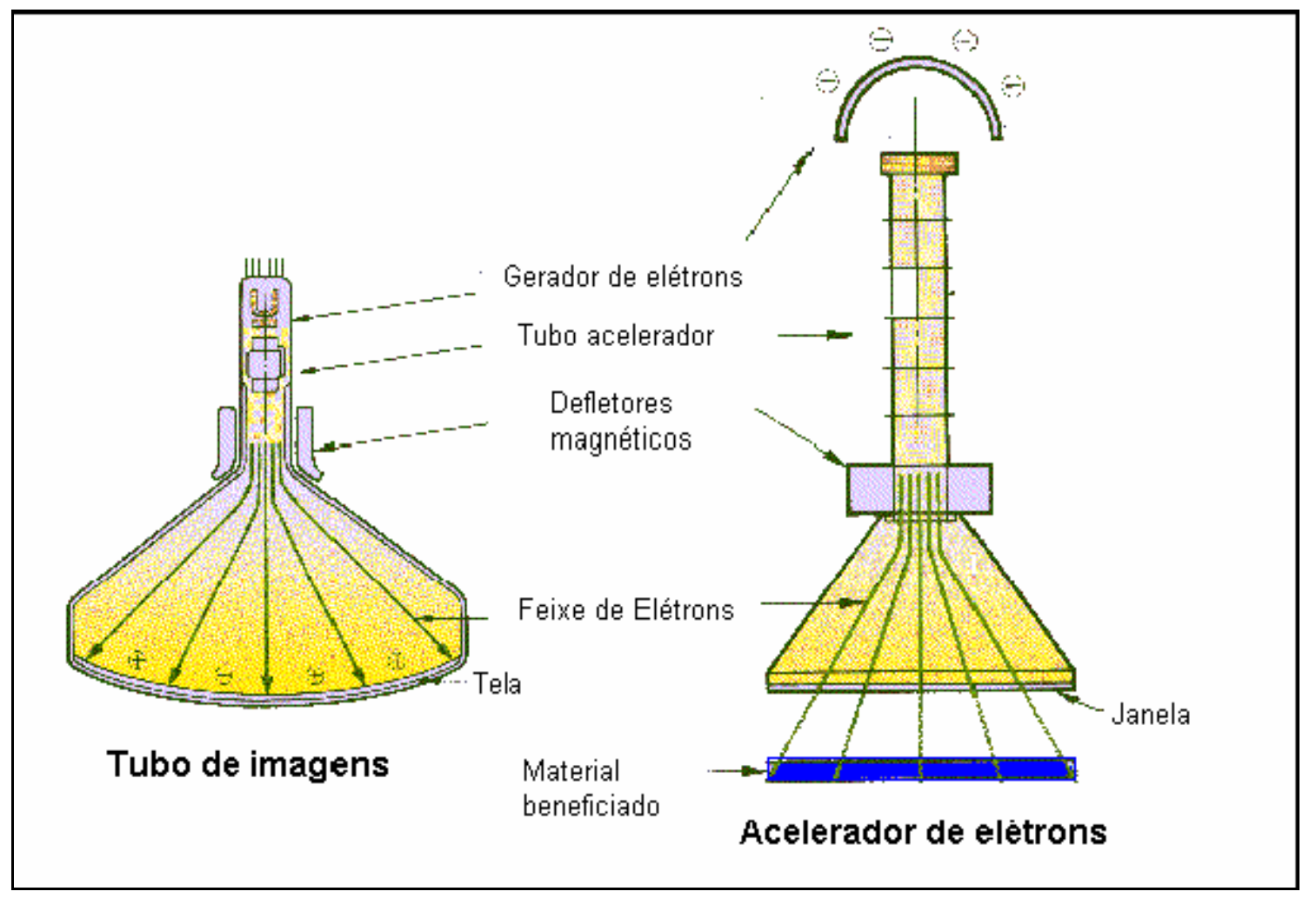

Figura 2.8. - llustração do princípio de funcionamento de acelerador de elétrons.

O princípio básico de qualquer acelerador é o campo elétrico que atua nos elétrons como se fossem as partículas carregadas, dando a eles energia 
igual à diferença de voltagem através do tubo de aceleração. O campo elétrico vem diretamente dos eletrodos de alta voltagem, nos aceleradores DC, ou indiretamente, originando-se da alteração dos campos magnéticos, nos aceleradores de alta freqüência e indução nos "Linacs" (aceleradores lineares). A principal diferença entre os tipos de aceleradores disponíveis está no método pelo qual o campo elétrico é gerado. Para níveis de energia elétrica acima de 5,0 MeV, o princípio de aceleração indireta é o mais prático (ZIMEK \& CHMIELEWSKI, 1998).

A dinâmica do feixe de elétrons apresenta uma dependência entre o movimento das partículas e parâmetros do campo na estrutura de aceleração, criando forças de interação com o feixe em movimento. O produto da intensidade do feixe ou corrente elétrica formada por partículas carregadas em movimento no acelerador de elétrons, expressa em mA (miliampere), pela energia do feixe, expressa em eV (elétron volt), corresponde à potência do feixe de elétrons. A potência média do feixe de elétrons está diretamente relacionada com o rendimento da taxa de dose de radiação, que deve ser mensurada pelo uso de sistemas dosimétricos adequados às várias faixas de doses.

Importante desenvolvimento tem sido conseguido nos sistemas de aceleração das máquinas aceleradoras de elétrons (SALIMOV, 1998) assim como nos sistemas de irradiação, que levam o material para a área de exposição à radiação, de modo a se obter o melhor rendimento da energia aplicada e redução de custos no processo (SAMPA et al, 1993 e RELA, 1999). CURRY et al(1998) demonstraram os avanços da tecnologia na fabricação de aceleradores com o objetivo de reduzir as dimensões das máquinas e o custo do investimento. Dentre os modelos mais atuais incluem-se os aceleradores "NHVG" ("nested high voltage generator"), que substituiu o isolamento da alta voltagem normalmente feito com o gás SF6 pelo isolamento sólido. Com isso houve um aprimoramento na eficiência da máquina que foi elevada para $83 \%$, sendo que em alguns estágios a eficiência atingiu 94\%. Outra nova geração de 
aceleradores considerados de voltagem ultra-alta é a dos aceleradores "Rhodotrons", cuja potência é induzida (gerada) por microondas ou radiofreqüência.

Em 1971 o Instituto de Física de Budker, na Rússia, iniciou o desenvolvimento e produção dos aceleradores chamados de "ELV" úteis tanto para aplicações industriais quanto para pesquisas. Essas máquinas cobrem uma faixa de energia entre 0,2 a 2,5 MeV, corrente até $40 \mathrm{~mA}$, atingindo a potência máxima de $400 \mathrm{~kW}$. Essa geração de aceleradores tem se destacado para as aplicações ambientais, sendo utilizados tanto para o tratamento de águas residuárias quanto para o tratamento de gases tóxicos. Estes últimos parecem ser uma das utilizações ambientais mais promissoras, com eficiência indiscutível. Plantas comerciais para processamento por radiações, a energia da radiação é limitada de modo a impossibilitar a indução de radioatividade nos produtos. Assim, a energia máxima para fótons é de $5,0 \mathrm{MeV}$, enquanto a energia máxima para elétrons é de 10,0 MeV (MCLAUGHLIN, 1989).

\subsection{Biorremediação de solo}

Com o objetivo principal de recuperar áreas degradadas, pesquisadores no mundo todo passaram a estudar a biorremediação in situ (SPILBORGHS, 1997). Nestes estudos utilizam-se microrganismos endêmicos capazes de transformar a matéria orgânica (madeira, solventes orgânicos, pesticidas, etc), em novas substâncias intermediárias ou à total degradação. Desta forma, estes organismos decompositores obtêm energia, água, sais minerais e gases, principalmente gás carbônico e metano. Neste caso, o poluente funciona como fonte de carbono, sendo necessário adicionar nitrogênio e fósforo, nutrientes específicos, sais minerais ou agentes oxidantes que funcionem como receptores de elétrons (SPILBORGHS, 1997). 
Para a utilização desta técnica inúmeros fatores devem ser observados, dentre eles destacam-se: o solo não pode possuir baixa permeabilidade (uma vez que isto dificultaria a penetração de água e nutrientes); potencial hidrogeniônico inferior a 5,5 (diminui a ação bacteriana; umidade muito baixa (inferior a 10\%), entre outros (SPILBORGHS, 1997).

$\mathrm{Na}$ utilização da biorremediação devemos inicialmente realizar a caracterização da área em estudo, sobretudo a sua potencialidade biológica, parâmetros hidrogeológicos, químicos e físicos. Desta forma, poderemos estimar o tempo de cura a qual estará relacionada com a alíquota de degradação dos compostos presentes, a disponibilidade destas substâncias, a quantidade de material contaminado, as condições climáticas, etc. (COOKSON Jr., 1995; KING et al., 1992).

Usualmente, a degradação microbiológica de solos e efetuada pelo método da compostagem. Este processo utiliza de pilhas do solo contaminado amontoadas em um espaço restrito, favorecendo a velocidade aeróbica de degradação microbiana. Para majorar a eficiência, adicionam-se ao processo, nutrientes e água, aumentando assim a umidade a qual favorece o crescimento de colônias de microrganismos decompositores (JØRGENSEN et al., 2000).

\subsection{Biodegradação de óleos}

Quimicamente, o petróleo é uma mistura complexa constituída de um grande número de compostos orgânicos, principalmente hidrocarbonetos. Óleos, geralmente são formados por compostos mais simples como alguns alcanos, ou até mesmo mais elaborados como os asfaltenos (ROQUE et al., 1994). Já os lubrificantes são constituídos por hidrocarbonetos de cadeias com número de átomos de carbono entre 26 e 38 . Os mais leves têm entre 18 e 25 átomos de carbono (BAKER \& HERSON, 1994). Torna-se importante ressaltar que a composição destes óleos são muito variáveis e dependem em muito de 
sua origem. Desta forma, os óleos comercializados (produzidos) no Brasil são, em regra, parafínicos.

Estudos recentes fazem referência aos hidrocarbonetos alifáticos, sendo estes os mais suscetíveis a degradação biológica que os aromáticos. Ao mesmo tempo, cadeias lineares são degradadas mais facilmente que cadeias ramificadas. Seguindo esta lógica, cadeias longas são mais prontamente degradadas que moléculas menores, uma vez que cadeias de tamanho menor que 9 carbonos são tóxicas aos microrganismos. A dimensão ideal de cadeias carbônicas está entre 10 e 20 átomos de carbono (BAKER \& HERSON, 1994). BAKER E HERSON (1994) afirmaram que a deterioração de hidrocarbonetos se dá especialmente por oxidação, assim átomos de oxigênio ligam-se ao carbono terminal, formando um álcool. Seqüencialmente, a reação continua oxidando o álcool ao aldeído correspondente e finalmente a um ácido, conforme esquema de oxidação a seguir:

$$
\mathrm{R}-\mathrm{CH}_{3} \longrightarrow \mathrm{R}-\mathrm{CH}_{2} \mathrm{OH} \longrightarrow \mathrm{R}-\mathrm{CHO} \longrightarrow \mathrm{R}-\mathrm{COOH}
$$

Hidrocarboneto Álcool Aldeído Ácido carboxílico

Recentemente, diversos acidentes, com conseqüente derramamento de óleos de diversas características, bem como o aumento na atenção despendida pela comunidade, levou ao desenvolvimento de pesquisas mais efetivas e com menores custos para a mitigação das condições advindas de derramamentos. 


\section{OBJETIVOS}

\subsection{Objetivo Geral}

Avaliar a toxicidade de fluidos de usinagem (sem uso e usados), através da ecotoxicologia aquática e propor atividades mitigadoras para seus possíveis impactos.

\subsection{Objetivos Específicos}

- Avaliar a toxicidade de lubrificantes através da realização de testes agudos com diferentes espécies (Daphnia similis, Daphnia Laevis, Cladocera, Crustácea e Danio rerio, Teleostei, Cyprinidae);

- Avaliar a toxicidade dos lubrificantes através da realização de testes agudos com bactéria marinha luminescente - Vibrio fischeri (sistema Microtox $($ );

- Avaliar processos de biodegradação para estes óleos em solo, ou seja, determinar que tipo de bactérias que melhor se adapta na decomposição deste tipo de material;

- Isolar cepas de bactérias que são capazes de degradar estes fluidos, identificando-as para criação de banco de informações em caso da utilização das mesmas na descontaminação de áreas contaminadas;

- Avaliar a degradação destes óleos através da exposição à radiação e assim determinar se esta técnica seria adequada no aumento da velocidade de degradação ou eliminação da toxicidade. 


\section{MATERIAIS E MÉTODOS}

\subsection{Escolha das amostras}

Inicialmente foram escolhidas quatorze amostras comerciais de fluido de usinagem de peças metálicas para este estudo. Estas amostras foram dividas em dois grupos, sendo sete amostras sem uso e outras sete amostras usadas por um período de tempo mínimo de um ano. Este período é considerado, segundo a literatura, o tempo médio de uso destes fluídos.

Após uma pesquisa detalhada sobre as diferentes composições destes fluidos, sua taxa de comercialização no mercado brasileiro e similaridade entre suas propriedades, constatou-se que algumas destas amostras não tinham representatividade no mercado brasileiro, ou tinham as mesmas características físicas e químicas. Desta forma, foram selecionados três fluidos que atingem $90 \%$ das vendas nacionais e são de grupos e composições diferentes. Logo, suas propriedades forneceriam resultado mais apropriado ao estudo proposto.

\subsection{Amostragem}

As amostras que chamaremos de A (sem uso) e A' (usada) representam os fluidos minerais solúveis. Este fluido é, segundo o fabricante, destinado à usinagem leve de metais. Possui aditivação, a qual the confere estabilidade de emulsão e grande poder de umectação e lubrificação. Possui também alta resistência microbiana, alto poder de refrigeração e inibidores de corrosão. 
Diferentemente das primeiras, as amostras B e B', sem uso e usada respectivamente, são produtos semi-sintéticos de ultima geração, desenvolvido para atender a crescente demanda das operações em metais, com a expectativa de uma baixa manutenção. Este fluido foi formulado a partir de matérias primas vegeto-animais, sendo considerado pelo fabricante não agressivo ao meio ambiente e seguro ao trabalhador. É especialmente indicado para retificar e usinar metais ferrosos e não ferrosos, tais como aço, ferro fundido, cobre e suas ligas de alumínio, ou seja, apresenta um espectro maior de possibilidades de uso e conseqüentemente, maior procura pelo fato de ser considerado biodegradável.

O terceiro lote de amostras, C e C', foi desenvolvido a partir de polímeros sintéticos, solúveis em água para a usinagem e retífica de materiais ferrosos e não ferrosos. Totalmente sintético, permite boa visualização do processo, não forma espuma (não contém gorduras) e possui baixa agressividade a derme.

Para o estudo, foram coletados 5 litros de cada fluido sem uso e usado junto à empresa fabricante. Estas amostras foram coletadas em frascos de plástico cinza para reduzir degradação quando em contato com a luz. Estas amostras, devido ao seu alto poder de lubrificação são comercializadas em uma forma diluída com concentração igual a $5 \%(\mathrm{v} / \mathrm{v})$. De acordo com os objetivos deste trabalho, optou-se por este tipo de produto, visto que estas seriam as encontradas na natureza em caso de acidente, ou seja, as informações aqui obtidas estariam mais próximas da realidade.

Como já citado, estes produtos possuem uma série de substâncias químicas adicionadas em sua fórmula. Os chamados aditivos propiciam ao produto maior segurança no uso e durabilidade. Por uma questão de segredo industrial, as empresas não fornecem as formulações completas, mas sabe-se que os biocidas são as principais substâncias adicionadas, as quais são 
responsáveis por evitar a contaminação dos fluidos por fungos e bactérias quando em uso nas máquinas e tensoativos, os quais aumentam a atividade do produto.

Após a coleta das amostras, as mesmas foram encaminhadas ao laboratório de Tecnologia das Radiações no Instituto de Pesquisas Energéticas e Nucleares - IPEN na Universidade de São Paulo. No laboratório, as amostras foram separadas em alíquotas de 500 e $1000 \mathrm{~mL}$ em frascos de vidro âmbar, para evitar a contaminação e conseqüentemente perda das amostras originais. Então, todos os frascos foram colocados em armários escuros em uma sala com temperatura média de $20^{\circ} \mathrm{C}$.

\subsection{Caracterização das amostras e determinação das variáveis físicas e químicas.}

Os parâmetros avaliados neste estudo estão descritos na Tabela 4.1. Esses elementos foram selecionados levando-se em conta a Legislação Federal que regulamente o descarte de produtos químicos nos corpos d'água. (D.O.U., 2005).

Todas as análises foram feitas de acordo com "Standard Methods for Water and Wastewater" (APHA, 1998). 
Tabela 4.1. - Parâmetros físicos e químicos avaliados no estudo das amostras de fluido A, A', B, B', C e C'.

\begin{tabular}{ccl}
\hline Parâmetros & Unidades & \multicolumn{1}{c}{$\begin{array}{c}\text { Método de análise/ } \\
\text { equipamentos empregado }\end{array}$} \\
\hline Cor & - & Colorimétrico, Hach DR 890 \\
$\mathrm{pH}$ & - & Medidor de pH, Digimed Dm2 \\
Temperatura & $\circ \mathrm{C}$ & Termômetro de mecúrio \\
Densidade & $\mathrm{g} \mathrm{cm}^{-3}$ & Densimetro Merck \\
DQO & $\mathrm{mg} \mathrm{L}^{-1} \mathrm{O}_{2}$ & Colorimétrico, Hach DR 890 \\
Compostos Fenólicos & $\mathrm{mg} \mathrm{L}^{-1}$ Fenol & Colorimétrico \\
Surfactantes & $\mathrm{mg} \mathrm{L}^{-1}$ & Colorimétrico, Hach DR 890 \\
\hline
\end{tabular}

As análises foram feitas nas amostras brutas (originais) para a verificação de suas propriedades e possíveis interferências nos testes de toxicidade. A demanda química de oxigênio - DQO foi realizada pelo refluxo com dicromato de potássio, titulado com uma solução padrão de sulfato ferroso amoniacal. Os surfactantes e compostos fenólicos foram determinados por colorimetria, baseados nos seguintes métodos: azul de metileno e ácido cromotrópico respectivamente.

\subsection{Avaliação da Toxicidade dos Fluidos}

Pode-se definir a toxicidade como sendo a resposta de um organismo a exposição (concentrada) de determinada toxina, por um período suficientemente longo. Quando feito, este estudo nos fornece informações que incorporam uma somatória dos processos causadores de estresse ao qual submete-se o organismo, assim como a capacidade de compensar tais efeitos (NIPPER, 2000).

Para este estudo, optou-se por testes agudos, visto que testes preliminares com diferentes espécies demonstraram que as amostras 
apresentavam alta toxicidade e inviabilizaria testes crônicos. Segundo CETESB (1997), a toxicidade aguda, normalmente expressa em concentração letal mediana (CL50) à qual representa $50 \%$ de mortalidade da população exposta, ou pela CE50 (concentração efetiva mediana a 50\% da população exposta), quando o efeito observado foi à imobilidade dos organismos expostos.

Na seleção da espécie de organismo a ser testada para a avaliação do impacto do lançamento de efluentes em corpos hídricos, objetivando a proteção da vida aquática, inicialmente recomenda-se obter resultados com no mínimo três espécies representativas de diferentes níveis tróficos. Após esta fase inicial, o controle e monitoramento do efluente pode passar a ser feito apenas com a espécie mais sensível. Tais procedimentos são muitos utilizados pois melhoram os resultados expressos na medida que a detecção da presença de diferentes substâncias tóxicas em uma determinada amostra é ampliada. Por exemplo, peixes são mais sensíveis ao cianeto do que a Daphnia, enquanto esta última é mais sensível a substâncias orgânicas (BASSOI E COL, 1990). Por esta razão, optou-se neste estudo em utilizar diferentes tipos de ensaios com organismos de níveis tróficos também diferentes. Com bactérias luminescentes (Vibrio fischerı), Daphnia similis (espécie exótica), Daphnia laevis (espécie nativa) e peixes (Danio rério).

\subsubsection{Bactérias Marinhas Vibrio fischeri - Sistema Microtox ${ }^{\circledR}$}

Neste teste, utilizou-se um Sistema Analisador de Toxicidade Microtox ${ }^{\circledR}$. Este equipamento é um espectrômetro modificado baseado na quantificação das variações na emissão de luz, por unidade de tempo, das bactérias de origem marinha, Vibrio fischeri (antiga Photobacterium phosphoreum). Há muito utiliza-se esta espécie; estudos originaram-se em 1979, quando BULICH desenvolveu a técnica, e a Beckman Instruments Inc patenteou e comercializou o Sistema Microtox ${ }^{\circledR}$, em 1982, hoje representado pela Azur Environment . 
Basicamente, o equipamento consiste em um fotômetro de precisão, o qual permite medir a luminescência emitida pela bactéria na presença e na ausência da substância tóxica, é acompanhado de culturas liofilizadas da bactéria, das células especiais para a leitura (cubetas), bem como dos reagentes necessários para a hidratação das bactérias liofilizadas, ajuste de salinidade (por serem bactérias marinhas) e diluição das amostras.

De forma geral, faz-se à execução do teste a partir de uma cultura liofilizada de bactérias, contendo $10^{8}$ células por ampola, a qual é hidratada quando da realização de um teste. Desta forma, as suspensões bacterianas são adicionadas à solução diluente (etapa1) e, posteriormente à leitura da luz inicial (etapa 2), adicionam-se a cada célula de leitura as respectivas frações da amostra correspondente a uma série de diluições da amostra a ser ensaiada (etapa 3) (CETESB, 1987 e APHA, 1995).

A inibição de quaisquer das inúmeras enzimas envolvidas nessa análise irá causar uma redução na produção da luz emitida pelas bactérias. Bioquimicamente, a luciferase (enzima) utiliza a flavina, um aldeído de cadeia longa, em sua forma reduzida, e oxigênio para a produção de luz. A emissão de luz é o resultado do processo total da célula, ou seja, é a expressão da resultante de uma série complexa de reações bioquímicas produtoras de energia.

Ao entrar em contato com as substâncias tóxicas as bactérias tem uma redução da capacidade de produção da luz. Tal fato pode ser comprovado através de medidas da quantidade de luz emitida por essas suspensões bacterianas antes e após o contacto com a amostra.

De acordo com os procedimentos estabelecidos no protocolo do teste básico do Sistema Microtox ${ }^{\circledR}$, o maior valor da concentração efetiva (letal) a $50 \%$ dos indivíduos do teste - CE50 que ele permite obter é de $50 \%$ quando a amostra não necessita de ajuste osmótico ou $45,45 \%$ quando o ajuste 
osmótico é necessário. Isto ocorre quando a salinidade for inferior a $2 \%$ (MICROBICS, 1994).

A resposta do teste é normalmente expressa pela concentração efetiva a metade dos organismos presentes no teste - CE50 que é calculada a partir da redução na quantidade de luz emitida pelo microrganismo-teste, após sua exposição ao agente tóxico, por um período de 15 minutos em condições padronizadas. A CE50 pode ser transformada em unidade tóxica, U. T., ou ainda pode ser expressa pelo valor do efeito gama (Г). Esse valor é obtido pela razão entre o decréscimo na quantidade de luz emitida pelo organismo-teste e a quantidade de luz remanescente nesse período. A CE-50 é a concentração da amostra que corresponde ao valor de gama igual a 1 (CETESB, 1987). 


\subsubsection{Testes Agudos com Daphnias, família Daphnidae, Ordem Cladocera}

Para avaliar a toxicidade das amostras em diferentes níveis tróficos, selecionou-se duas espécies de daphnias. Estes organismos foram mantidos em laboratório para controle de variáveis, tais como: iluminação, temperatura, alimentação entre outros e preparação para os bioensaios.

\subsubsection{Testes preliminares}

Os testes preliminares são feitos para se determinar a faixa de concentração da solução-teste a ser utilizada no teste definitivo, onde delimitase a menor concentração que causa imobilidade a $100 \%$ dos organismos e a concentração mais elevada na qual não se observa este efeito.

Para a definição das concentrações das substâncias de referência, serviram como base valores obtidos em uma série de ensaios preliminares feitos no Laboratório de Ecotoxicologia Aquática do IPEN serviram como base.

\subsubsection{Testes definitivos}

A metodologia adotada na avaliação da toxicidade aguda dos fluidos de usinagem baseou-se nas normas da ASTM (1988), CETESB (1992), ABNT (1993) e USEPA (2003).

De acordo com estes métodos, o teste consiste em expor jovens de $D$ similis e $D$ laevis, com idade entre 6 e 24 horas, as amostras de fluido de usinagem. Deste modo, determinou-se quais das amostras testadas causaram imobilidade dos organismos em um período de 48 horas de exposição. 
Os testes foram feitos em tubos de ensaio aferidos para $10 \mathrm{~mL}$. Para cada amostra preparou-se quatro réplicas com cinco organismos cada, mais um controle com água de cultivo, ou seja, água de uma fonte natural e, dureza ajustada entre 40 a $48 \mathrm{mg} \mathrm{L}^{-1} \mathrm{de} \mathrm{CaCO}_{3}$.

Durante o período dos testes os organismos não foram alimentados, sendo mantidos em incubadoras a $20^{\circ} \mathrm{C} \pm 1^{\circ} \mathrm{C}$, na ausência de luz, evitando interferências causadas pela luminosidade.

Ao término do teste, os organismos foram examinados quanto à sua mobilidade, com auxílio de um microscópio estereoscópico marca "Wild Heerbrugg", modelo M5. Os organismos que após 15 segundos não se movimentaram foram considerados imóveis (CETESB, 1992).

Durante os testes foram observados os seguintes requisitos para considerá-los válidos: a mortalidade no controle não exceder a 10\% e a temperatura da água na faixa de $20^{\circ} \mathrm{C} \pm 1^{\circ} \mathrm{C}$. Além dos testes de toxicidade, foram realizados testes de viabilidade para a avaliação da qualidade da água de cultivo.

$\mathrm{Na}$ análise estatística dos dados obtidos, foi utilizado o programa computacional "TOXSTAT" (GULLEY et al, 1991). A fim de verificar se houve diferença significativa entre as amostras, foi utilizado o teste de comparações múltiplas de Tukey e de Kruska II-Wallis. 


\subsubsection{Separação dos organismos-teste}

No dia anterior ao teste, algumas fêmeas ovígeras foram separadas das culturas, para isso foi utilizada uma pipeta Pausteur com borda arredondada. As Daphnias separadas foram colocadas em um béquer limpo, com água de cultivo e alimento, sendo posteriormente o recipiente coberto com filme plástico para a proteção da cultura.

Para a montagem do teste, após a reprodução, as fêmeas adultas foram retiradas com a pipeta e recolocadas nas culturas originais. Desta forma, isolou-se os organismos jovens, os quais foram mantidos em incubadora para que fiquem dentro da faixa adequada para teste ( 6 a 24 horas).

\subsubsection{Testes de sensibilidade}

Estes testes são feitos com uma substância de referência. $O$ objetivo principal deste teste é verificar as condições em que os organismos se encontram no momento do teste (qualidade), sendo que o resultado deve se encontrar dentro de uma faixa conhecida de sensibilidade a uma substância tóxica de referência.

Para a execução dos testes, fez-se a exposição do organismo-teste a um curto período de seu ciclo de vida a diferentes concentrações dos fluidos de usinagem de peças metálicas. O tempo de desenvolvimento variou geralmente de 24 a 48 h para Daphnia.

A avaliação da sensibilidade foi feita empregando-se ensaios com $D$. similis e $D$. laevis com, dicromato de potássio, e com cloreto de sódio, substâncias chamadas de referência, usualmente utilizadas para avaliar o grau de "saúde" dos organismos. Em virtude de ser uma espécie nova e com poucos 
trabalhos publicados, os testes de $D$. laevis foram comparados com os resultados obtidos a $20^{\circ} \mathrm{C}$ para $D$. similis.

Para a solução mãe, foram diluídos $2.10^{4} \mathrm{mg} \mathrm{L}^{-1}$ de cloreto de sódio, com dureza ajustada para 40-48 $\mathrm{mg} \mathrm{L}^{-1}$ de $\mathrm{CaCO}_{3}$. A partir desta solução foram obtidas soluções-teste com concentrações de $500 \mathrm{mgL}^{-1} ; 1.10^{3} \mathrm{mgL}^{-1} ; 2.10^{3}$ $\mathrm{mgL}^{-1} ; 4.10^{3} \mathrm{mgL}^{-1} ; 8.10^{3} \mathrm{mgL}^{-1}$.

A partir da solução-mãe dicromato de potássio de $1.10^{3} \mathrm{mgL}^{-1}$ foram obtidas as soluções com concentrações de $2.10^{-2} \mathrm{mgL}^{-1} ; 4.10^{-2} \mathrm{mgL}^{-1} ; 8,5.10^{-2}$ $\mathrm{mgL}^{-1} ; 1,7.10^{-2} \mathrm{mgL}^{-1} ; 3,5.10^{-2} \mathrm{mgL}^{-1}$.

Os testes foram feitos em tubos de ensaio aferidos para $10 \mathrm{~mL}$. Foram colocados $8 \mathrm{~mL}$ da solução-teste, cinco organismos, e completou-se o volume com a solução-teste. Para cada concentração foram preparadas quatro réplicas. Para cada teste preparou-se um controle com $10 \mathrm{~mL}$ de água destilada com dureza ajustada, com quatro réplicas contendo cada uma 5 organismos.

O efeito observado para os organismos foi a imobilidade. Os organismos que não apresentaram movimentação em um intervalo de 15 segundos foram considerados imóveis (CETESB, 1991; USEPA, 1993).

Os resultados obtidos foram expressos em $\mathrm{CE}(\mathrm{I}) 50$, ou seja, a concentração que cause o efeito letal a $50 \%$ dos organismos expostos (RAND et al, 1995).

Foram observados os seguintes requisitos durante os testes para considerá-los válidos: mortalidade inferior a 10\% dos organismos expostos no controle, o teor de oxigênio não deve ser menor do que $2 \mathrm{mg} \mathrm{L}^{-1}$ e a temperatura da água deve estar na faixa de $20^{\circ} \mathrm{C}\left( \pm 2^{\circ} \mathrm{C}\right)$. 
A análise estatística dos dados foi feita com o auxílio do programa computacional "LC50 Programs JSpear Test" (HAMILTON et al., 1977), no qual foi determinada a $\mathrm{CE}(\mathrm{I}) 50 ; 24 \mathrm{~h}$ e $\mathrm{CE}(\mathrm{I}) 50 ; 48 \mathrm{~h}$ foi determinada.

Para os testes com os organismos aquáticos, primeiramente faz-se o cultivo e manutenção dos espécimes em laboratório.

\subsection{Cultivo e Manutenção de Daphnia similis e Daphnia laevis em laboratório}

Os cultivos de $D$. similis foram iniciados a partir de lotes fornecidos pelo Laboratório de Aplicações Nucleares para a Engenharia (TE-IPEN), e posteriormente pelo Laboratório de Análises TECAM - Tecnologia Ambiental Ltda. Os cultivos de $D$. laevis foram iniciados com exemplares obtidos junto ao Laboratório de Ecotoxicologia da Universidade Federal de São Carlos, anteriormente cultivados a $25^{\circ} \mathrm{C}$ (Figuras 4.1 e 4.2 ).

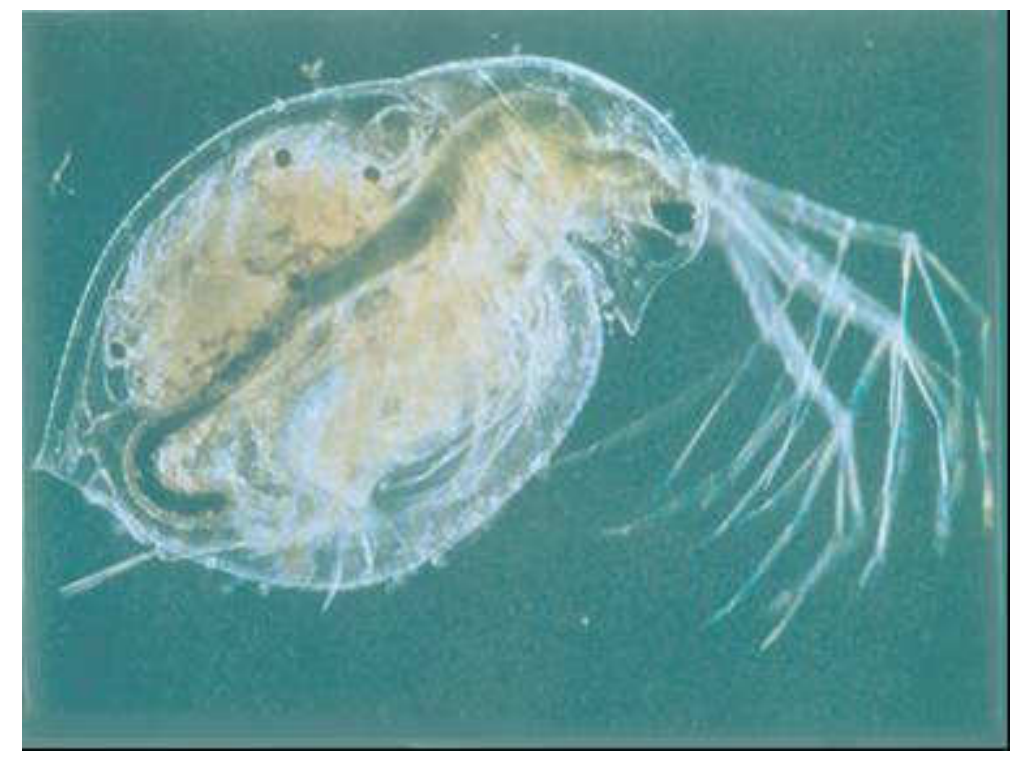

Figura 4.1 - Fêmea embrionada de Daphnia similis.

Fonte: SETAC (2001) 


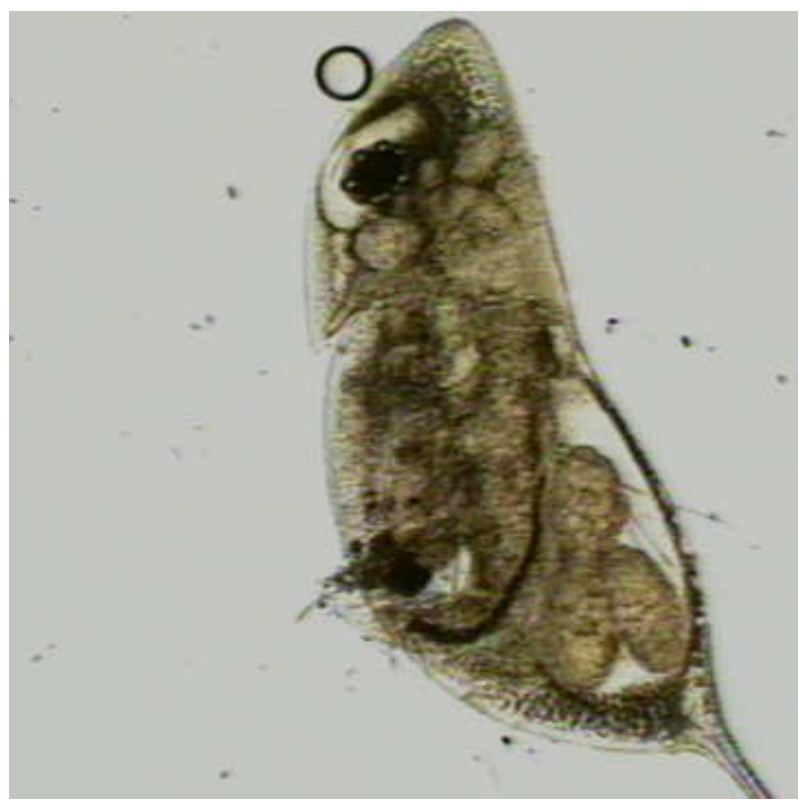

Figura 4.2 - Daphnia laevis adulta.

(Fonte: cfb.unh.edu,2006)

\subsubsection{Temperatura, fotoperíodo e intensidade luminosa}

As culturas-estoque e os cultivos individuais foram mantidos em incubadoras FANEM, modelo $347 \mathrm{CDG}$ a $20^{\circ} \mathrm{C} \pm 1^{\circ} \mathrm{C}$ para $D$. similis e $D$. laevis. O fotoperíodo adotado foi de 16 horas-luz e intensidade luminosa de 2000 lux.

\subsection{2. Água de Cultivo}

Para a manutenção dos organismos em laboratório é necessário se realizar coletas de água de boa qualidade ( $\mathrm{pH}$ próximo a 7 , alta concentração de oxigênio dissolvido, baixo teor de sólidos, entre outros), desta forma, reservatórios com este tipo de água são selecionados.

Como meio para os cultivos foram testadas águas de três fontes diferentes: Condomínio Vista Alegre (Vinhedo), Condomínio Aldeia da Serra (Barueri) (Figura 4.3) e Sistema Cantareira - Reservatório Paiva Castro, (Figura 4.4 e 4.5). As coletas foram feitas quando necessário, sendo 
acondicionadas em galões de 20 litros. No laboratório, foram mantidas no escuro. Antes de ser utilizada, a água foi filtrada em papel de filtro qualitativo para a eliminação de folhas, gravetos e organismos zooplanctônicos, especialmente larvas de insetos (predadoras do plâncton).

Monitorou-se a qualidade da água, em cada lote, medindo-se os valores de $\mathrm{pH}$, dureza e condutividade. De acordo com a Norma L5. 018 CETESB (1991), as variações mensais destes parâmetros devem ser consideradas, sendo que as alterações de $\mathrm{pH}$ não podem ultrapassar 0,7 unidades de sua média e os demais parâmetros não podem exceder mais do que $10 \%$ de suas médias. Estas variáveis foram avaliadas no controle da água da seguinte forma:

A - Temperatura da água - Termômetro do oxímetro marca Orion, modelo 810.

B - Concentração de oxigênio dissolvido e porcentagem de saturação Oxímetro marca Orion, modelo 810.

C - pH - Potenciômetro marca Digimed, modelo Dm2.

D - Condutividade - Condutivímetro marca Orion, modelo 150.

As Figuras 4.3 a 4.5 apresentam os locais de coleta de água para a manutenção das culturas de microrganismos para testes de toxicidade. 


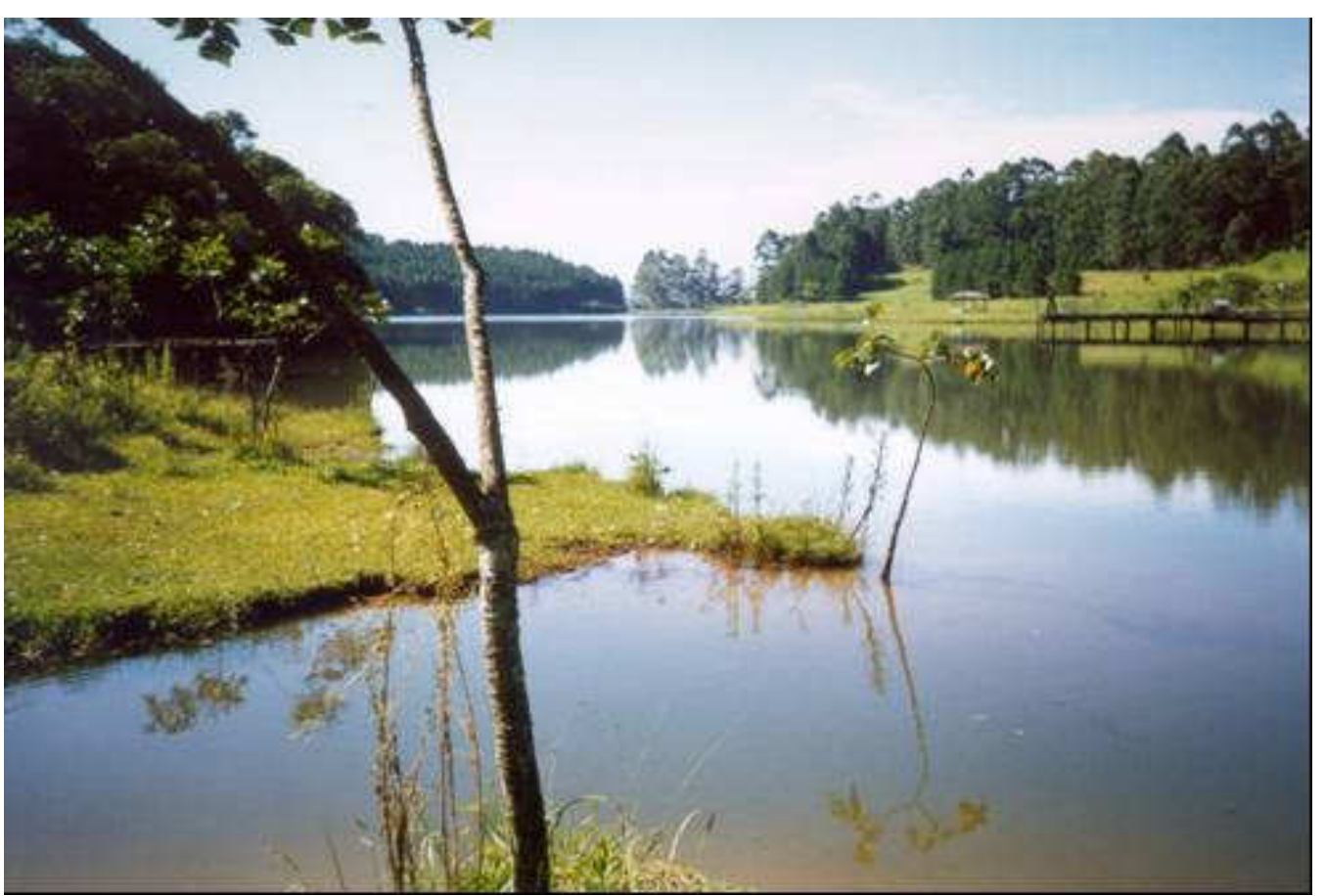

Figura 4.3 - Reservatório Aldeia da Serra, Barueri, São Paulo, SP.

Fonte : Sempla/Deinfo1999

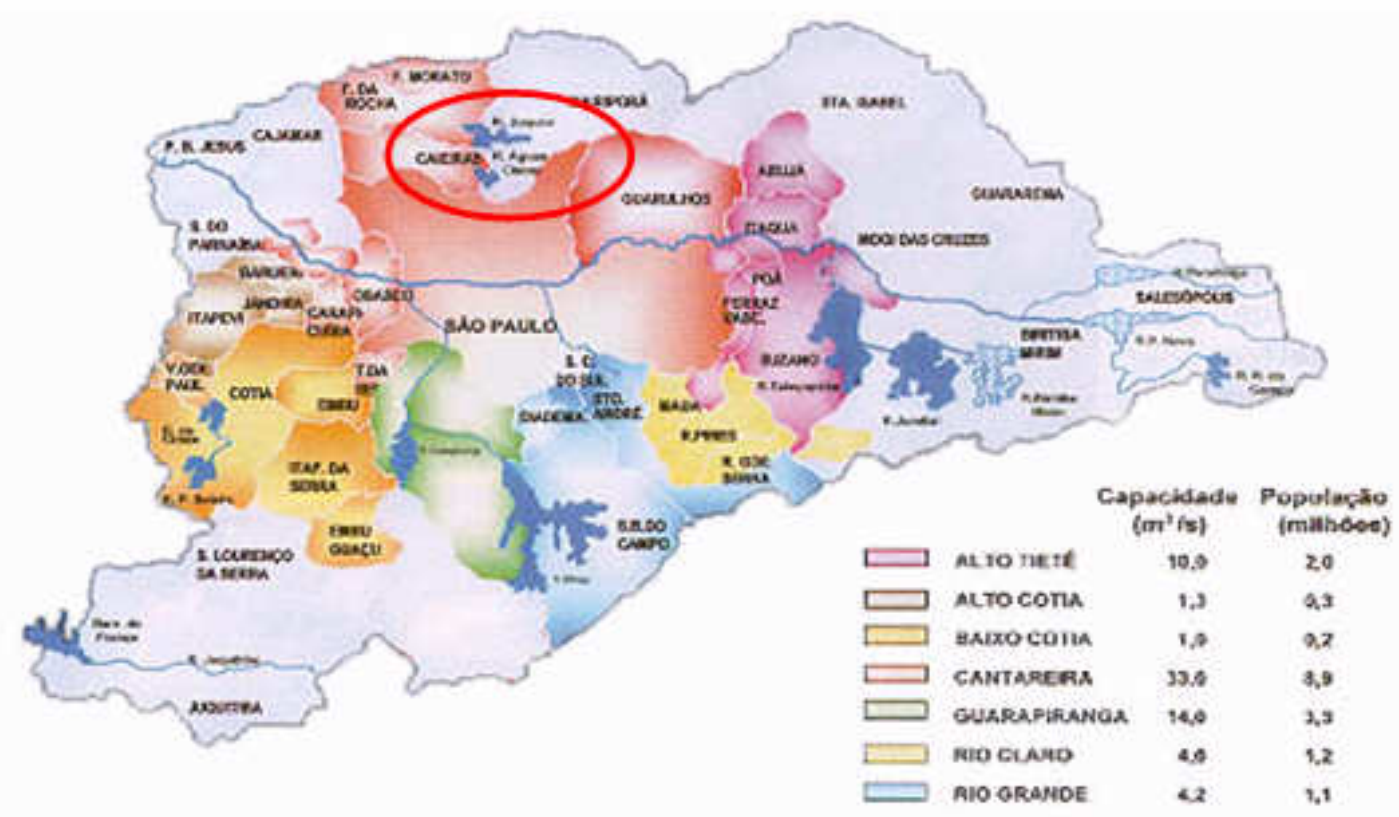

Figura 4.4 - Sistema Metropolitano de Abastecimento, em destaque a localização da Represa Paiva Castro, Mairiporã, São Paulo, SP. 


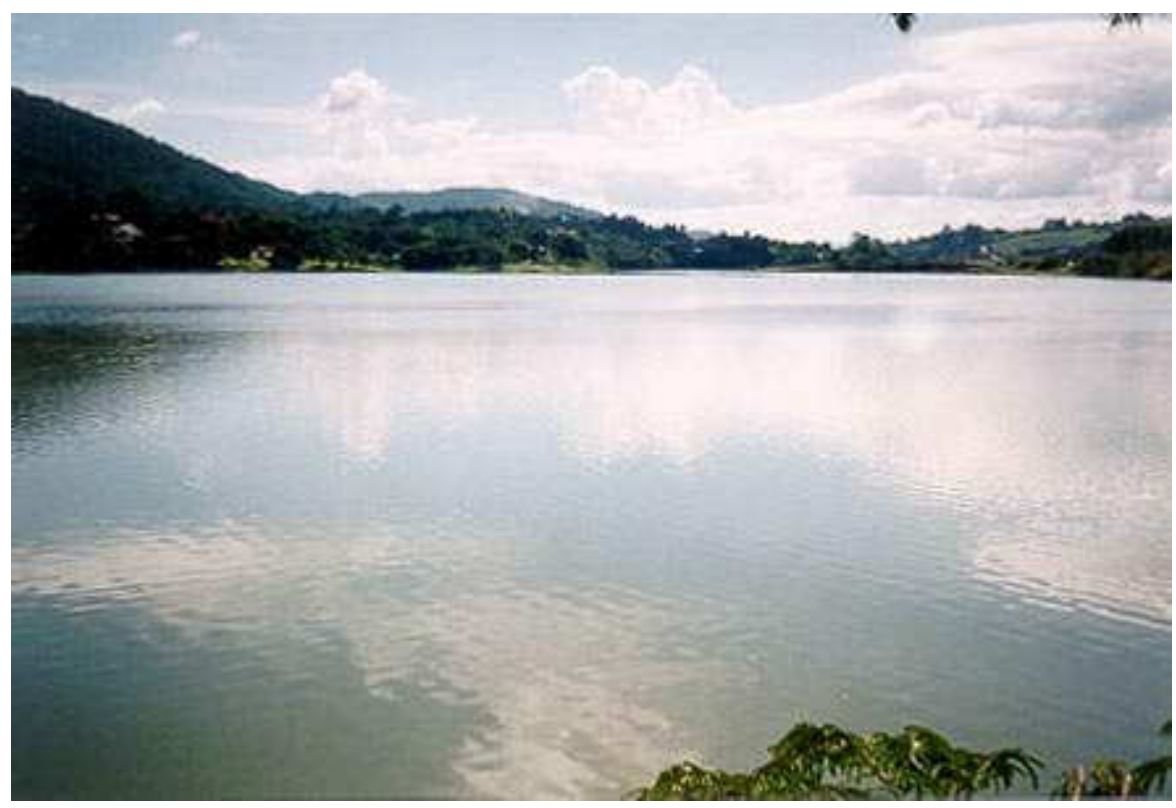

Figura 4.5 - Represa Paiva Castro, Mairiporã, São Paulo, SP.

\subsubsection{Teste de viabilidade da água de cultivo}

Para determinar a qualidade da água de cultivo, de cada lote de água foi feito um teste de viabilidade, de acordo com o procedimento descrito pela Norma CETESB (1991). Dez organismos da espécie Daphnia similis foram dispostos em $100 \mathrm{~mL}$ de água de cultivo, em cinco béqueres de $200 \mathrm{~mL}$, por um período de 48 horas, nas condições de manutenção dos cultivos-estoques e individuais.

Após o período de 48 horas, observou-se o número de organismos móveis e imóveis. A aceitabilidade do lote de água ocorre quando a porcentagem de imobilidade não exceder a $10 \%$ dos organismos expostos. 


\subsubsection{Culturas-estoque de $D$. similis}

Para coibir a intoxicação dos organismos pelo acúmulo de metabólitos e evitar interferências causadas por superpopulação (como, por exemplo, produção de efípios), realizou-se três vezes por semana a manutenção das culturas. Para tanto, a água foi trocada e cada indivíduo observado (Figura 4.5), impossibilitando a permanência de machos ou efípios gerados nos cultivos. Este procedimento foi feito utilizando microscópio estereoscópico marca Wild Heerbrugg, modelo M5.

\subsubsection{Cultivo individual de Daphnia laevis}

Inicialmente, foram feitos cultivos individuais de Daphnia laevis em béqueres de $30 \mathrm{~mL}$, preenchidos com $25 \mathrm{~mL}$ de água de cultivo (Figura 4.6). Após alguns testes, verificou-se que o cultivo em massa seria mais apropriado por apresentar maior estabilidade nas culturas, ou seja, menor mortandade.

As trocas de água foram feitas três vezes por semana (segunda, quarta e sexta-feira), quando observações sobre o número e o sexo dos filhotes eram feitas, com o auxílio de um microscópio estereoscópio marca Wild Heerbrugg, modelo M5, assim como a verificação das condições das mães. 


\subsection{Testes de toxicidade com peixes - Danio rerio - Teleostei, Cyprinidae.}

\subsubsection{Princípios do teste.}

Os ensaios foram feitos em aquários pequenos (2,0 L de capacidade), com concentrações diferentes de amostra através de ensaios estáticos, sem troca parcial de amostra (CETESB, 1991). Três réplicas foram preparadas com dez organismos cada, mais um controle com água de cultivo, com dureza ajustada entre 40 a $48 \mathrm{mg} \mathrm{L}^{-1}$ de $\mathrm{CaCO}_{3}$ e com os parâmetros físicos e químicos ( $\mathrm{pH}$, oxigênio dissolvido) medidos no inicio do teste e a cada 24 horas. Os peixes foram expostos a substância teste por um período de 96 horas. A mortalidade foi avaliada em 24, 48, 72 e 96 horas e a concentração letal a $50 \%$ dos indivíduos do ensaio (EC50) foi determinada.

Todos os peixes foram obtidos junto a CETESB e permaneceram em observação pelo período de 12 dias, mantidos com 12 a 16 horas de luz diárias, temperatura média de $2^{\circ} \mathrm{C}$ e oxigênio dissolvido acima de $8 \mathrm{mg} \mathrm{L}^{-1}$. Os testes foram realizados com iluminação ambiente e com temperatura controlada $\left(25 \pm 1,0^{\circ} \mathrm{C}\right)$. A água de cultivo para estes organismos, foi a mesma utilizada nas outras culturas do laboratório e possuem as mesmas características físicas e químicas dos daphnideos. Para a escolha dos peixes, foram selecionados machos e fêmeas com $2 \pm 1 \mathrm{~cm}$, sendo os mesmos observados quanto à mobilidade, cor, respiração, antes da inserção nas soluções - teste.

As soluções de amostras utilizadas foram preparadas no dia anterior ao teste e mantidas nos aquários para um condicionamento adequado (solubilização, estabilidade, etc). 


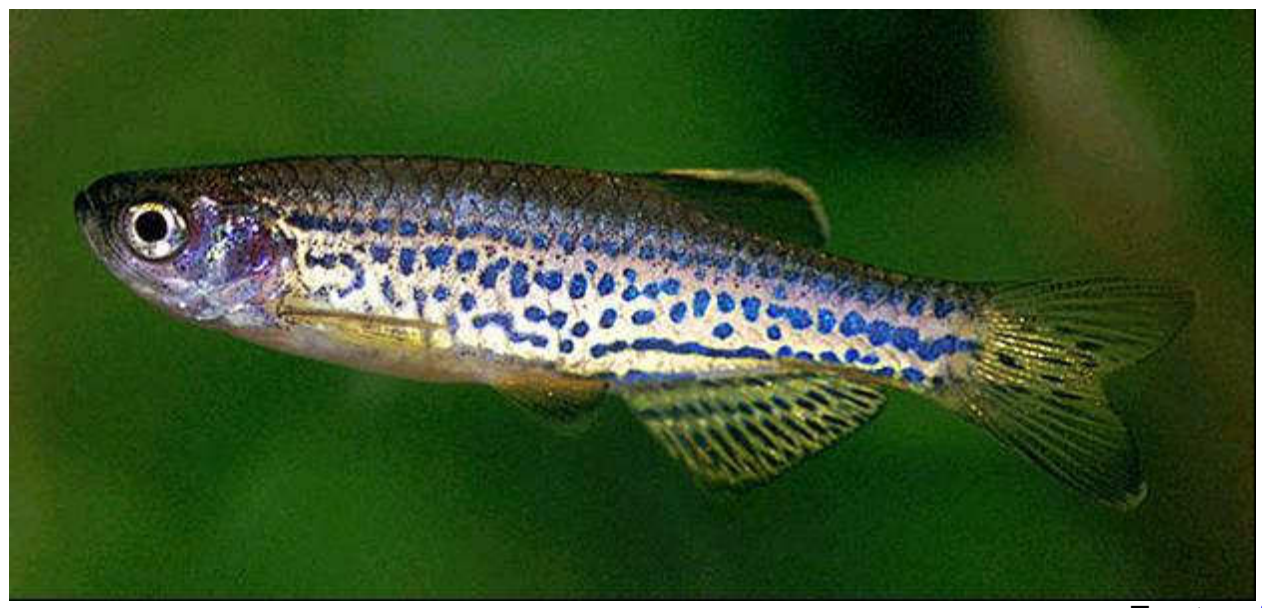

Fonte: $\underline{\text { JJPhoto }}$

Figura 4.6 - Danio rerio adulto.

Além da avaliação da toxicidade dos fluidos de usinagem, métodos para a degradação destes compostos também serão estudados, dentre estes, a irradiação por feixes de elétrons tem destaques em diversos estudos sobre amostras complexas como as de fluido de usinagem.

\subsection{Irradiação das amostras de fluido}

As amostras de fluido de corte para a usinagem de peças metálicas foram submetidas a radiação gama para verificar a susceptibilidade de degradação dos componentes tóxicos presentes na matriz estudada. Desta forma, procurou-se avaliar se o tratamento aplicado era eficiente na remoção da toxicidade.

\subsubsection{Procedimentos utilizados na irradiação das amostras de fluido de usinagem}

$\mathrm{Na}$ aplicação da irradiação, foi utilizado um Acelerador Industrial de Elétrons modelo Dynamitron, com potência de $37,5 \mathrm{~kW}$, energia até 1,5 MeV e 
corrente até $25 \mathrm{~mA}$ disponível no Centro de Tecnologia das Radiações, CTR/IPEN.

Para uma irradiação homogênea, foi utilizado um recipiente de vidro tipo Pyrex ${ }^{\circledR}$, respeitando uma espessura de $4,0 \mathrm{~mm}$ de amostra, de modo a garantir a distribuição da energia recebida por toda a camada de fluido submetido à radiação. Às amostras foram expostas ao feixe de elétrons protegidas com filme plástico, sendo transportadas até a área de irradiação por uma bandeja móvel, cuja velocidade foi ajustada em 6,72 $\mathrm{m}$ por minuto.

As doses nominais de irradiação foram selecionadas a partir da energia fixada em 1,4 MeV, variação da corrente elétrica conforme as doses necessárias e a movimentação da amostra sob o feixe também com velocidade constante. A confirmação das doses desejadas se fez por meio de filmes dosimétricos. As doses de radiação aplicadas foram: 10 kGy e 100 kGy.

Após as avaliações iniciais da toxicidade, foram estabelecidas as doses anteriormente citadas (mais usadas em experimentos com irradiação). Após este processo, as amostras foram levadas de volta ao laboratório de testes de toxicidade, onde permaneceram por um período de estabilização (24 horas) e então utilizadas nos testes com organismos. Optou-se por um resultado mais rápido e que pudesse fornecer uma idéia das condições da amostra, desta forma, bactérias luminescentes foram a escolha mais adequada.

Para uma melhor avaliação das propriedades dos fluidos de usinagem, o estudo de sua dinâmica em um ambiente natural torna-se necessário, desta forma, a avaliação da degradação destes compostos em solo e água foi realizado. 


\subsection{Biodegradação de poluentes orgânicos e biorremediação de águas e solo contaminado com fluidos de usinagem}

Para melhor avaliar o comportamento dos fluidos no meio e sua possível degradação quando em contato com os diferentes compartimentos ambientais, em especial solo e água, estudos de degradação foram propostos. Desta forma, selecionou-se duas formas básicas de degradação das amostras: 1 - teste padrão de biodegradabilidade em água e, 2 - teste de biodegradabilidade em solo. Para o segundo teste, foi desenvolvido um teste novo, o qual utiliza microrganismos presentes no solo como degradadores e não anelídeos como consta na literatura. Esta opção foi considerada porque espécies endêmicas poderiam ser mais apropriadas na decomposição dos fluidos de usinagem, caso ocorressem acidentes com este tipo de produto, algo não factivel quando organismos - padrão fossem expostos a substâncias como os fluidos de usinagem.

Como os ambientes aquáticos acabam por receber grande parte dos despejos realizados pelo homem, um estudo da biodegradabilidade dos fluidos de usinagem para este meio fez-se necessário.

\subsubsection{Testes de Biodegradabilidade}

Foram conduzidos testes de biodegradabilidade em água de acordo com OECD (2002).

Em um filtro de fibra de vidro (GFC) $0,45 \mu \mathrm{m}$, foi adicionada uma alíquota de 2,0 $\mathrm{mg} \mathrm{L}^{-1}$ da amostra, inoculada com uma pequena quantidade de microrganismos em um frasco para análise da demanda bioquímica de oxigênio (DBO), completamente cheio e lacrado. A degradação é observada através da análise de oxigênio dissolvido, por um período de 28 dias, sendo 
feitas leituras no instante da montagem $\left(\mathrm{t}_{0}\right)$ e a cada 7 dias. A quantidade de oxigeno dissolvido consumida pela população microbial foi, ao final do teste, um indicativo do potencial de biodegradabilidade da amostra.

A decomposição dos fluidos de usinagem em solo por microrganismos endêmicas foi avaliada com o intuito de conhecer, isolar e manter em laboratório cepas de bactérias que pudessem auxiliar na limpeza de um sitio em caso de derramamentos acidentais.

\subsubsection{Identificação de Microrganismos Decompositores}

Para este estudo, preparou-se reatores cilíndricos preenchidos com solo coletado na região da represa do Ribeirão do Lobo, São Carlos São Paulo. Este solo que serviu de base para a degradação, foi seco em estufa a aproximadamente $40^{\circ} \mathrm{C}$ e em seguida peneirado para uma melhor homogenização e eliminação de possíveis compostos inibidores. Após esta etapa, dividiu-se quatro grupos de reatores: controle, o qual continha apenas o solo contaminado na concentração de $1 \mathrm{~mL} \mathrm{~kg}^{-1}$ (para cada um dos fluidos de usinagem foi montado um reator independente); tratamento com turfa, contendo o solo contaminado e adicionando-se turfa na quantidade correspondente a $10 \%$ da massa do solo; microrganismos de solo, contendo 0 solo contaminado e adicionando-se borra retirada de um fluido de usinagem vegetal obtida após o uso do mesmo, devendo conter os microrganismos responsáveis por sua degradação; compostagem, contendo o solo contaminado e microrganismos obtidos de um sistema de degradação caseiro. Os reatores e o esquema de montagem são apresentados na Figura 4.7. 


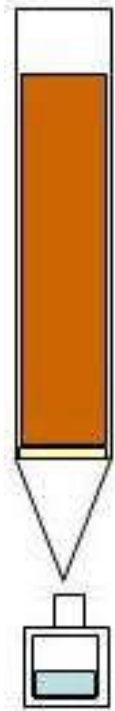

Coluna contendo solo contaminado

Filtro de espuma

Frasco para coleta de água
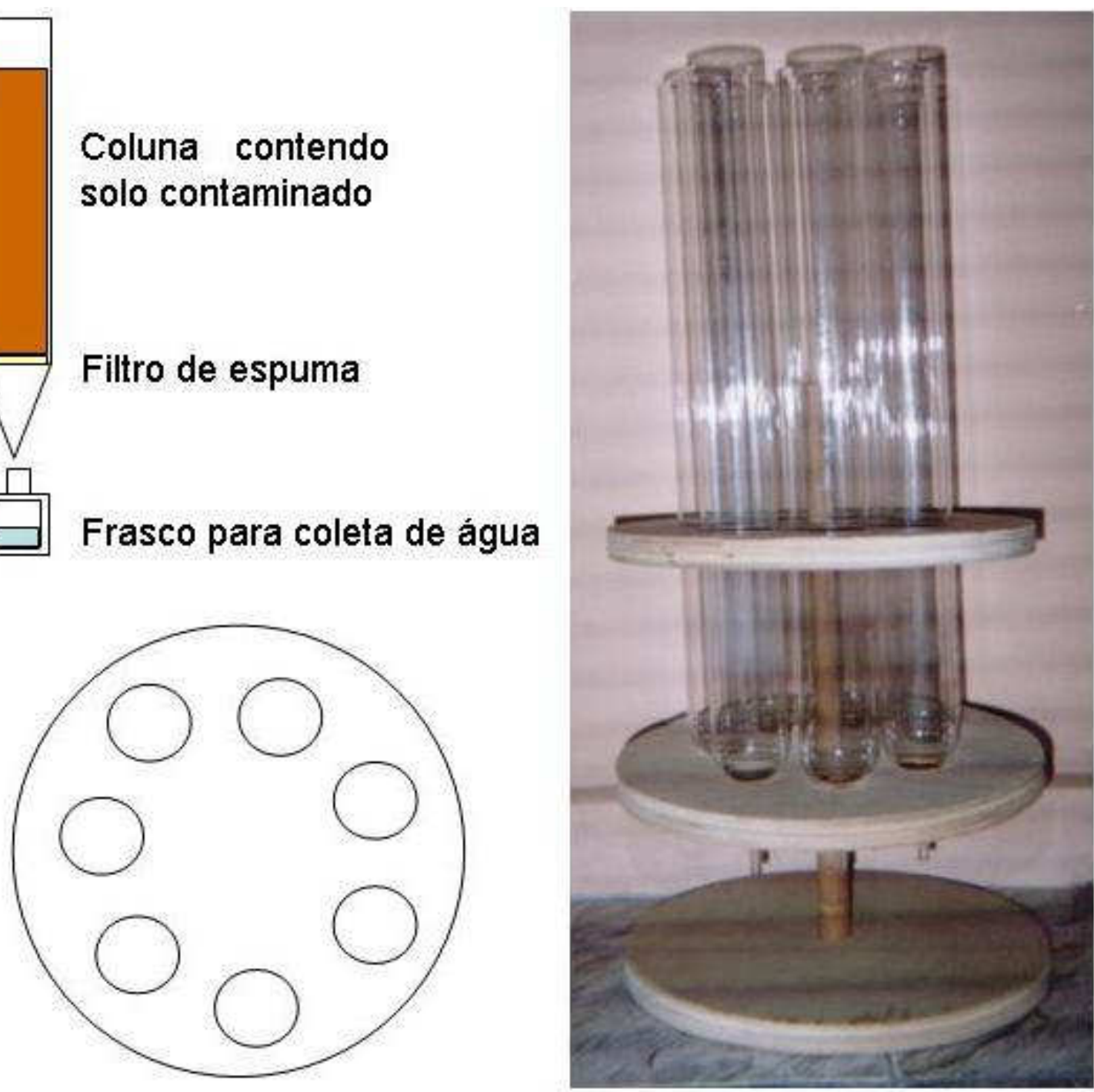

Fonte: (AMARANTE JR, 2003).

FIGURA 4.7. - Esquema de montagem do experimento de degradação.

Os experimentos foram conduzidos, expondo-se os reatores às intempéries por um período de 186 dias, retirando-se duas amostras de cada reator com uma periodicidade de aproximadamente 30 dias. Neste estudo, cabe ressaltar que os fluidos estavam sujeitos à ação da temperatura, da luz, das chuvas, além da degradação microbiológica.

Para avaliar o efeito de tais fatores, foram obtidos os dados meteorológicos da região, medidos na estação climatológica situada no Centro de Recursos Hídricos e Ecologia Aplicada (CRHEA - SHS - EESC - USP). 
Foram efetuados, também, estudos de degradação em estufa, com a temperatura mantida em $20^{\circ} \mathrm{C}$. Assim, frascos contendo $20 \mathrm{~g}$ de solo contaminado com cada um dos lubrificantes foram mantidos nestas condições por 30 dias. Deste modo, pôde-se observar a degradação dos fluidos de usinagem apenas por ação dos microrganismos, uma vez que os demais parâmetros foram mantidos sob controle. Sendo possível uma perda por volatilização, como via alternativa, considerando-se que o material foi mantido sob aquecimento.

Das amostras de solo contaminadas com os diferentes fluidos foram retiradas alíquotas de um grama (1g). Misturou-se então, $10 \mathrm{~mL}$ de água desionizada estéril, obtendo-se assim uma solução contendo os microrganismos que estavam presentes na degradação. Destas soluções, foi retirada uma alíquota de $1 \mathrm{~mL}$, sendo diluído em mais $9 \mathrm{~mL}$ de água desionizada estéril. Estes procedimentos foram seguidos até uma concentração de $10^{-4}$ e $10^{-5}$ organismos por mililitro.

Todas as diluições foram executadas em meio estéril com vidrarias aferidas e em capela de fluxo laminar, a fim de se evitar qualquer contaminação ou erro analítico. Após esta etapa, preparou-se meios de cultura padrão, com ágar (1,5\%) e o fluido correspondente a cada amostra $(20 \%)$. Inoculou-se então, os microrganismos previamente recuperados das amostras de solo. Meios de cultura contendo fonte de carbono alternativa também foram preparados, utilizando-se batata $(20 \%)$, dextrose $(2 \%)$, Agar $(1,5 \%)$ e fluido (5\%), chamado DBA (dextrose-batata-ágar), inoculando-se com os microrganismos da amostra correspondente.

Os meios de cultura após preparados e esterilizados empregando-se autoclave a $121 \stackrel{\circ}{\circ} \mathrm{C}$ por 20 minutos, foram mantidos em temperatura ambiente e foi observado o crescimento de colônias de bactérias e fungos, os quais foram separados para os meios adequados para estudos posteriores. Assim, para 
bactérias, foi preparado meio contendo extrato de levedura $(0,5 \%)$, peptona (1\%), $\mathrm{NaCl}(1 \%)$, agar (1,5\%). Após a separação das colônias de bactérias e suas purificações, efetuou-se o teste de coloração de Gram e estudo morfológico. Para os fungos, o mesmo meio, contendo batata e dextrose, produzido anteriormente foi empregado, adicionando-se sulfeto de estreptomicina como agente bactericida. Após a purificação das linhagens de fungos, efetuou-se o estudo morfológico. O esquema empregado para as diluições e inoculação é apresentado na Figura 4.8.
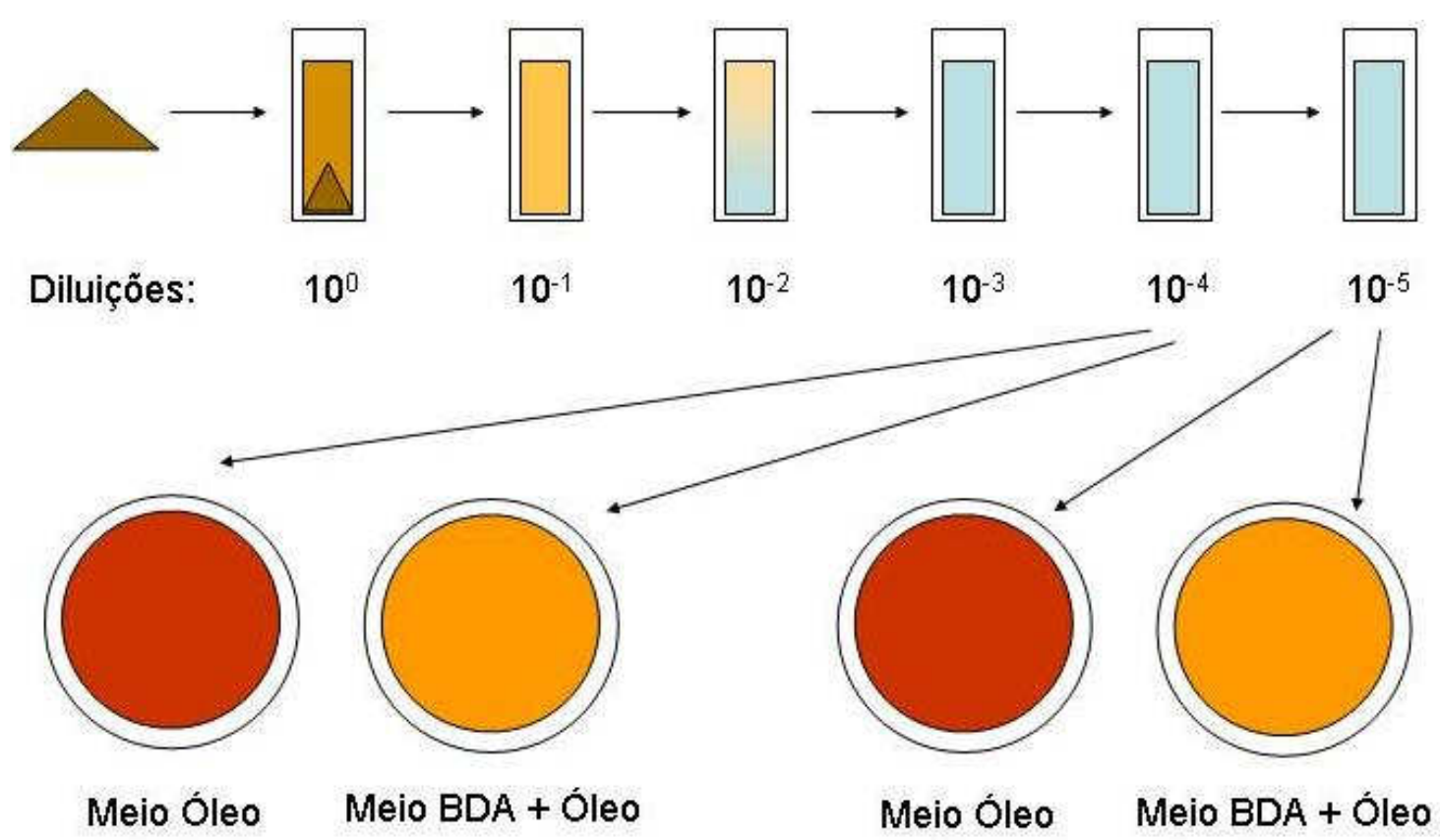

Fonte: (AMARANTE JR, 2003)

FIGURA 4.8 - Procedimento utilizado no preparo das amostras. 


\subsubsection{Identificação de bactérias por ácidos graxos.}

Após o preparo das amostras para a verificação dos microrganismos responsáveis pela biodegradação (se bactérias, fungos, etc.) propôs-se um estudo que identifica as bactérias presentes nas amostras de fluido de usinagem para uma possível utilização destas cepas em eventuais acidentes ambientais que viessem a ocorrer. Desta forma, separou-se as amostras com as colônias bacterianas mais desenvolvidas, ou seja, as que melhor se adaptaram ao meio e se reinoculou em uma nova solução contendo somente meio Agar (1,5\%). Estas amostras foram então levadas a EMBRAPA Jaguariúna para que se processassem os testes de identificação.

Foram transferidos $40 \mathrm{~g}$ de massa de células para tubos de cultura de $13 \times 100 \mathrm{~mm}$. Estas amostras são saponificadas com 1,0 $\pm 0,1 \mathrm{~mL}$ do reagente contendo $45 \mathrm{~g}$ de $\mathrm{NaOH}, 150 \mathrm{~mL}$ de metanol e $150 \mathrm{~mL}$ de água desionizada. Agitou-se em agitador tipo "vortex" por 10 segundos, aqueceu-se por 5 minutos em banho-maria a $100^{\circ} \mathrm{C}$, agitou-se novamente por 10 segundos, reaquecendo-se por mais 25 minutos, resfriando-se, em seguida, em banho de água até atingir temperatura ambiente.

Realiza-se então a metilação dos ácidos graxos com a adição de 2,0 $+0,1 \mathrm{~mL}$ do reagente, que consiste em uma mistura de $325 \mathrm{~mL}$ de ácido clorídrico $6,0 \mathrm{~mol} \mathrm{~L}^{-1}$ e $275 \mathrm{~mL}$ de metanol, agitou-se por $10 \mathrm{~s}$, aqueceu-se a $80^{\circ} \mathrm{C}$ por $10 \mathrm{~min}$ e resfriou-se em banho de água até temperatura ambiente. Os ésteres formados são extraídos com 1,25 mL de um sistema de solventes, constituído de hexano e terc-butil-metil éter na proporção 50:50, agitando-se levemente em agitador clínico por $10 \mathrm{~min}$. Separou-se a fase orgânica contendo as substâncias de interesse, lavando-se o extrato com 3,0 mL de solução de $\mathrm{NaOH}$ (10,8 g em $900 \mathrm{~mL}$ de água desionizada) e agitando-se por 5 min. Observando-se a formação de emulsão, os tubos foram centrifugados a 
2000 RPM por 3 min. A fase orgânica foi separada e armazenada em frascos tipo "vials" de $2 \mathrm{~mL}$ para a posterior análises em cromatógrafo.

As análises cromatográficas foram efetuadas em Cromatógrafo a Gás Agilente CG 6850, empregando amostrador automático, coluna capilar Ultra 2 e detector de lonização em Chama (DIC). As condições cromatográficas empregadas foram aquelas descritas por SASSER, 1990.

Com os cromatogramas obtidos, houve a identificação dos microrganismos comparando-se as informações contidas na biblioteca do sistema Microbial ID, Inc., Newark, Dell. Os dados obtidos consistem na indicação de uma identidade provável da bactéria investigada e do grau de similaridade. 


\subsection{Análise Estatística}

De forma geral, o grande número de dados experimentais causam dificuldades em sua interpretação e compreensão. Com o objetivo de minimizar este problema, utilizam-se testes estatísticos para sua avaliação (LEMES, 2001).

Uma análise da variância ANOVA, seguida do teste e comparações múltiplas de Tukey foi realizada para os dados das variáveis ambientais e, dos testes de toxicidade obtidos nos experimentos realizados no estudo.

A análise estatística empregada para calcular os valores da CE50 dos testes Microtox ${ }^{\circledR}$ foram realizadas com a Versão 7.82 do programa desenvolvido pela Microbics Corp., a partir dos valores do efeito gama em função das concentrações de amostra testadas. O mesmo tipo de análise estatística foi empregada para os cálculos de CE50 e CL50 dos testes com os daphnideos e com os peixes. A partir do número de organismos que morreram durante a exposição em função das concentrações testadas. O método estatístico Trimmed Spearman Karber, com correção de Abott, foi aplicado para calcular tanto os valores de CE50 para ambos os testes bem como os intervalos de confiança (HAMILTON, 1977). 


\section{RESULTADOS E DISCUSSÃO.}

5.1. Determinação das variáveis físicas e químicas dos fluidos de usinagem.

Foram feitas análises físicas e químicas em todas as amostras de fluido. As tabelas 5.1 - 5.6 apresentam os resultados paras as amostras A, A', B, B', C, C' respectivamente.

Tabela 5.1. - Parâmetros físicos e químicos da amostra de fluido A (fluido mineral sem uso)

$\begin{array}{ccc}\text { Parâmetros } & \text { Unidades } & \text { Valores } \\ \text { Cor } & - & \text { âmbar } \\ \mathrm{pH} & - & 9,5 \\ \text { Temperatura } & \varrho \mathrm{C} & 23 \\ \text { Densidade } & \mathrm{g} \mathrm{cm}^{-3} & 0,860 \\ \text { DQO } & \mathrm{mg} \mathrm{L}^{-1} \mathrm{O}_{2} & 86 \\ \text { Compostos fenólicos } & \mathrm{mg} \mathrm{L}^{-1} \mathrm{fenol}^{-1} & <0,01 \\ \text { Surfactantes } & \mathrm{mg} \mathrm{L}^{-1} & <0,01\end{array}$


Tabela 5.2. - Parâmetros físicos e químicos da amostra de fluido A' (fluido mineral usado).

$\begin{array}{ccc}\text { Parâmetros } & \text { Unidades } & \text { Valores } \\ \text { Cor } & - & \text { âmbar } \\ \mathrm{pH} & - & 8,9 \\ \text { Temperatura } & \varrho \mathrm{C} & 23 \\ \text { Densidade } & \mathrm{g} \mathrm{cm}^{-3} & 0,825 \\ \text { DQO } & \mathrm{mg} \mathrm{L}^{-1} \mathrm{O}_{2} & 74 \\ \text { Compostos fenólicos } & \mathrm{mg} \mathrm{L}^{-1} \text { fenol } & <0,01 \\ \text { Surfactantes } & \mathrm{mg} \mathrm{L}^{-1} & <0,01\end{array}$

Verifica-se pelas Tabelas 5.1 e 5.2 que os valores dos parâmetros físicos e químicos para o fluido mineral sem uso e usado são praticamente os mesmos, excetuando-se o pH que é menor no fluido usado muito provavelmente em decorrência do período de uso sofrido pelo mesmo e, sua possível diluição com água.

Tabela 5.3. - Parâmetros físicos e químicos da amostra de fluido B (semi sintético sem uso).

$\begin{array}{ccc}\text { Parâmetros } & \text { Unidades } & \text { Valores } \\ \text { Cor } & - & \text { Castanho claro } \\ \mathrm{pH} & - & 10 \\ \text { Temperatura } & \circ \mathrm{C} & 24 \\ \text { Densidade } & \mathrm{g} \mathrm{cm}^{-3} & 0,996 \\ \text { DQO } & \mathrm{mg} \mathrm{L}^{-1} \mathrm{O}_{2} & 112 \\ \text { Compostos fenólicos } & \mathrm{mg} \mathrm{L}^{-1} \text { fenol }^{-1} & <0,01 \\ \text { Surfactantes } & \mathrm{mg} \mathrm{L}^{-1} & <0,01\end{array}$


Tabela 5.4. - Parâmetros físicos e químicos da amostra de fluido B' (semi sintético usado).

$\begin{array}{ccc}\text { Parâmetros } & \text { Unidades } & \text { Valores } \\ \text { Cor } & - & \text { Castanho escuro } \\ \mathrm{pH} & - & 9,5 \\ \text { Temperatura } & \circ \mathrm{C} & 24 \\ \text { Densidade } & \mathrm{g} \mathrm{cm}^{-3} & 0,950 \\ \text { DQO } & \mathrm{mg} \mathrm{L}^{-1} \mathrm{O}_{2} & 98 \\ \text { Compostos fenólicos } & \mathrm{mg} \mathrm{L}^{-1} \text { fenol } & <0,01 \\ \text { Surfactantes } & \mathrm{mg} \mathrm{L}^{-1} & <0,01\end{array}$

Nas tabelas 5.3 e 5.4 observa-se os mesmos fatores na amostra de fluido semi-sintético vistos para o fluido mineral, ou seja, somente o $\mathrm{pH}$ sofreu uma pequena redução em função de seu uso na usinagem de peças metálicas.

Tabela 5.5. - Parâmetros físicos e químicos da amostra de fluido C (polímero sintético sem uso).

$\begin{array}{ccc}\text { Parâmetros } & \text { Unidades } & \text { Valores } \\ \text { Cor } & - & \text { castanho } \\ \mathrm{pH} & - & 9,5 \\ \text { Temperatura } & \circ \mathrm{C} & 23 \\ \text { Densidade } & \mathrm{g} \mathrm{cm}^{-3} & 1,060 \\ \text { DQO } & \mathrm{mg} \mathrm{L}^{-1} \mathrm{O}_{2} & 330 \\ \text { Compostos fenólicos } & \mathrm{mg} \mathrm{L}^{-1} \text { fenol }^{-1} & <0,01 \\ \text { Surfactantes } & \mathrm{mg} \mathrm{L}^{-1} & <0,01\end{array}$


Tabela 5.6. - Parâmetros físicos e químicos da amostra de fluido C' (polímero sintético usado).

$\begin{array}{ccc}\text { Parâmetros } & \text { Unidades } & \text { Valores } \\ \text { Cor } & - & \text { Castanho claro } \\ \mathrm{pH} & - & 9,3 \\ \text { Temperatura } & \stackrel{\circ}{\mathrm{C}} & 24 \\ \text { Densidade } & \mathrm{g} \mathrm{cm}^{-3} & 1,005 \\ \text { DQO } & \mathrm{mg} \mathrm{L}^{-1} \mathrm{O}_{2} & 280 \\ \text { Compostos fenólicos } & \mathrm{mg} \mathrm{L}^{-1} \mathrm{fenol}^{-1} & <0,01 \\ \text { Surfactantes } & \mathrm{mg} \mathrm{L}^{-1} & <0,01\end{array}$

Os resultados anteriormente apresentados mostram que existe certa similaridade entre todas as amostras, contudo a composição desses fluidos varia muito. Desta forma, estes parâmetros são referência para possíveis estudos junto aos corpos de água natural, pois são variáveis amplamente usadas em estudos de limnologia.

Todas as amostras apresentavam cor, e este parâmetro, apesar de ser uma característica exigida pelos fabricantes de fluidos, servem como indicadores de qualidade aos operadores, esta característica interfere de forma drástica nos bioensaios, isto porque, torna difícil a visualização dos organismos, e consequentemente, alteram as condições de predação dos mesmos. Para reduzir este efeito, as amostras tiveram de ser diluídas há um ponto em que esta interferência ficasse bem reduzida. As partículas que produzem cor ao fluido, provocam a dispersão da luz, dando à água uma aparência nebulosa, esteticamente indesejável causando assim, uma redução da produção dos sistemas subaquáticos. Além disso, observa-se que a densidade das amostras esta muito próxima a da água, produzindo desta forma uma mistura que interfere em toda a coluna d' água, desde a superfície até o fundo, e isso causa danos aos diferentes níveis tróficos (PERSON, 1979). 
Os valores de $\mathrm{pH}$ mostram que todas as amostras possuem caráter básico. Como são valores elevados (acima de 9), estão fora da faixa adequada aos testes propostos neste estudo e, portanto, foram previamente ajustados com a adição de ácido clorídrico a $0,1 \mathrm{~mol} \mathrm{~L}^{-1}$. No Brasil a água dos rios, lagos e represas, apresentam um caráter de ácido a neutro, e seu $\mathrm{pH}$ nas amostras dos fluidos é básico. Em caso de um despejo desses fluidos, todo o compartimento seria afetado. Cabe lembrar ainda que 0 potencial hidrogeniônico é medido em uma escala logarítmica e uma pequena alteração em seu valor implica em grandes diferenças na dinâmica do corpo hídrico.

Segundo a literatura, o teste da DQO (demanda química de oxigênio) é sobremaneira precioso na medida da matéria orgânica em despejos de esgotos domésticos ou efluentes industriais, ou seja, permite a avaliação da carga orgânica de poluição de esgotos domésticos e industriais em termos da quantidade de oxigênio necessária para a sua total oxidação em dióxido de carbono e água (RICHTER, 1998).

A DQO apresentou valores menores para as amostras A e A' (fluido mineral sem uso e usado respectivamente) em decorrência das mesmas serem sintéticas e consequentemente com menor quantidade de material orgânico. As demais, por possuírem mais componentes orgânicos, tiveram um incremento nos valores da DQO o que as tornam mais danosas aos recursos hídricos, pois causam a diminuição da quantidade de oxigênio dissolvido, condição de sobrevivência dos organismos. Segundo ESTEVES (1990), baixas concentrações de oxigênio, causa inúmeras implicações sobre o metabolismo do ecossistema como um todo, principalmente ao provocar alterações na fauna bentônica, zooplanctônica e sobre as algas.

Em condições extremas, ou em um processo avançado de eutrofização, excesso de nutrientes como nitrogênio e fósforo, o oxigênio é consumido totalmente, criando condições anaeróbias ou anóxicas. Além disso, a oxidação 
destes fluidos, que é um processo natural realizado por microrganismos presentes na água (entre as quais predominam as bactérias aeróbias), todo o oxigênio dissolvido na água, demanda bioquímica de oxigênio - DBO é consumido, conduzindo a morte todos os organismos aeróbios de respiração subaquática (BRANCO, 1986). Outra conseqüência deste processo é a presença de gás sulfídrico (ácido sulfídrico - $\mathrm{H}_{2} \mathrm{~S}$ ) nas águas. Esta substância é tóxica e apresenta letalidade aos peixes na concentração de 1 a $6 \mathrm{mg} \mathrm{L}^{-1}$, é corrosivo e contribui em grande parte nos processos de corrosão das estruturas de concreto utilizados para a canalização. Isso causa sérios problemas de odor e sabor na água, sendo responsável pelo mau cheiro característico dos locais poluídos. A maior parte dos sulfetos, por serem agentes redutores, são responsáveis por uma demanda imediata de oxigênio dissolvido, diminuindo ainda mais a concentração de oxigênio nos esgotos (BRAILE, 1979).

Não foram encontrados compostos fenólicos nas amostras de fluido estudados. Os fenóis são de importância elevada nos processos de produção, pois é comprovadamente cancerígeno e causa assim, problemas aos operadores que ficam em contato com o produto. A contaminação de águas usadas para consumo humano por fenol pode levar ao incremento da incidência de distúrbios gastro-intestinais (RICHARDSON \& GANGOLLI, 1992). Na natureza, também causam danos aos sistemas aquáticos, pois são tóxicos aos organismos através da acumulação em algas e consequentemente nos organismos que se alimentam delas produzindo um efeito cascata.

Surfactantes, ou basicamente detergentes, são responsáveis pela formação de espuma, provocando danos estéticos ao corpo d'água, bem como problemas de contaminação humana, quando essas espumas são carregadas pelo vento. No Brasil, é comum a utilização de alquilbenzeno sulfonatos lineares - LAS, como aditivos nos fluidos. Em conjunto com este surfactante, são adicionados aditivos fosfatados que funcionam como seqüestradores de partículas coloidais, os quais são os principais causadores da eutrofização dos 
recursos hídricos, especialmente em sistemas lênticos (TEIXEIRA, 1997). Para a indústria de usinagem de peças metálicas, não é interessante a presença de surfactantes, pois o mesmo causa a formação de espuma e dificulta o processo de preparação de uma peça metálica. Desta forma, dificilmente estes compostos são adicionados nos fluidos comerciais.

De acordo com as análises físicas e químicas feitas com os fluidos, verifica-se que os parâmetros avaliados estão de acordo com os limites da legislação para e emissão despejos em rios da classe 2 (D.O.U., 2005). Porém segundo ZAGATTO (2006), somente através de bioensaios é possível indicar se as águas apresentam condições adequadas ou não à manutenção da vida aquática, pois assim pode-se detectar possíveis efeitos sinergéticos ou antagônicos.

\subsection{Avaliação da Toxicidade dos Fluidos}

De acordo com a legislação CONAMA N.ำ357 (D.O.U.,2005), os padrões de qualidade das águas estabelecidos constituem-se em limites individuais para cada substância. Considerando eventuais ações sinérgicas entre as mesmas, as não especificadas, não poderão conferir às águas características capazes de causar efeitos letais ou alteração de comportamento, reprodução ou fisiologia da vida, ou seja, a resposta dos organismos aquáticos à substâncias ou misturas tóxicas é mais sensível quando comparadas com parâmetros físicos e químicos, sendo considerados indicador global da toxicidade de um sistema receptor (CETESB, 1990).

Segundo SOARES (1990), testes ecotoxicológicos complementam e diminuem os custos tradicionais de controle da poluição e, quando integrados em um programa multidisciplinar, são indispensáveis para uma política correta de gestão dos recursos naturais. 


\subsubsection{Bactérias Marinhas Vibrio fischeri - Sistema Microtox ${ }^{\circledR}$}

Foram feitos inúmeros testes preliminares para chegar a uma faixa de concentração adequada aos estudos. Após definidas as concentrações, fez-se 5 testes definitivos para cada amostra.

Para as amostras de fluido mineral ( $A$ e $\left.A^{\prime}\right)$, houve um problema maior pois as mesmas apresentavam uma coloração intensa, fazendo com que houvesse interferência no método, com isso foi necessário a diluição das amostras de fluido.

As Tabelas 5.7 e 5.8 apresentam os valores da concentração efetiva para os testes com as amostras dos fluidos minerais (teste de 15 minutos). Empregou-se neste estudo quatro concentrações diferentes e um branco. Estas concentrações variaram de $0,050 \%$ a $0,0050 \%$ sendo preparadas a partir de uma solução estoque com concentração igual a 1\% em água.

Tabela 5.7 - Concentração letal a $50 \%$ dos indivíduos para a amostra A (fluido mineral sem uso).

\begin{tabular}{c|c|c|c|c}
\hline Teste & CE 50 (\%) & \multicolumn{2}{|c}{ Intervalo de Confiança } & Fator de Confiança \\
\hline 1 & 0,0102 & 0,0093 & 0,0111 & 1,0960 \\
\hline 2 & 0,0135 & 0,0129 & 0,0142 & 1,0381 \\
\hline 3 & 0,0160 & 0,0150 & 0,0169 & 1,0609 \\
\hline 4 & 0,0149 & 0,0143 & 0,0156 & 1,0442 \\
\hline 5 & 0,0153 & 0,0147 & 0,0160 & 1,0489 \\
\hline Media & 0,0139 & 0,0132 & 0,0147 & 1,0576 \\
\hline
\end{tabular}

CE - concentração efetiva 
Tabela 5.8 - Concentração letal a $50 \%$ dos indivíduos para a amostra A' (fluido mineral usado).

\begin{tabular}{c|c|c|c|c}
\hline Teste & CE 50 (\%) & \multicolumn{2}{|c|}{ Intervalo de Confiança } & Fator de Confiança \\
\hline 1 & 0,0046 & 0,0040 & 0,0052 & 1,1388 \\
\hline 2 & 0,0056 & 0,0050 & 0,0062 & 1,1405 \\
\hline 3 & 0,0042 & 0,0048 & 0,0059 & 1,1632 \\
\hline 4 & 0,0061 & 0,0053 & 0,0069 & 1,1503 \\
\hline 5 & 0,0039 & 0,0033 & 0,0045 & 1,1608 \\
\hline Media & 0,0049 & 0,0045 & 0,0057 & 1,1507 \\
\hline
\end{tabular}

CE - concentração efetiva

Verifica-se pelos dados das Tabelas 5.7 e 5.8, que a concentração letal para $50 \%$ dos indivíduos do teste para o fluido mineral sem uso (A) ficou em torno de $0,0139 \%$ e $0,0049 \%$ para o fluido mineral usado (A'). Desta forma, verifica-se que a amostra usada apresenta uma toxicidade muito maior que a nova. Como estes fluidos permanecem em operação por alguns meses, ficando em contato com várias partes móveis das máquinas, é provável ocorrer uma contaminação do fluido durante seu uso. Os componentes presentes no fluido usado causaram uma toxicidade aguda muito mais efetiva (quase que três vezes maior) quando comparada com a amostra sem uso.

As tabelas 5.9 e 5.10 apresentam os resultados dos testes de toxicidade quando empregou-se bactéria luminescente para do fluido semisintético sem uso e usado (B e B'). 
Tabela 5.9 - Valores da concentração letal a 50 \% dos indivíduos para a amostra B (fluido semi - sintético sem uso).

\begin{tabular}{c|c|c|c|c}
\hline Teste & CE 50 (\%) & \multicolumn{2}{|c|}{ Intervalo de Confiança } & Fator de Confiança \\
\hline 1 & 0,0192 & 0,0179 & 0,0207 & 1,0754 \\
\hline 2 & 0,0160 & 0,0144 & 0,0179 & 1,1150 \\
\hline 3 & 0,0183 & 0,0177 & 0,0189 & 1,0895 \\
\hline 4 & 0,0201 & 0,0190 & 0,0212 & 1,1312 \\
\hline 5 & 0,0177 & 0,0170 & 0,0184 & 1,0862 \\
\hline Media & 0,0182 & 0,0172 & 0,0194 & 1,0994 \\
\hline
\end{tabular}

CE - concentração efetiva

Tabela 5.10 - Valores da concentração letal a 50 \% dos indivíduos para a amostra B' (fluido semi - sintético usado).

\begin{tabular}{c|c|c|c|c}
\hline Teste & CE 50 (\%) & \multicolumn{2}{l|}{ Intervalo de Confiança } & Fator de Confiança \\
\hline 1 & 0,0256 & 0,0248 & 0,0266 & 1,1052 \\
\hline 2 & 0,0228 & 0,0222 & 0,0234 & 1,1257 \\
\hline 3 & 0,0270 & 0,0264 & 0,0276 & 1,0898 \\
\hline 4 & 0,0248 & 0,0240 & 0,0256 & 1,1824 \\
\hline 5 & 0,0266 & 0,0258 & 0,0274 & 1,1181 \\
\hline Media & 0,0242 & 0,0234 & 0,0250 & 1,1201 \\
\hline
\end{tabular}

CE - concentração efetiva

A amostra de fluido semi-sintético sem uso (B) teve CE $50 \%$ médio de $0,0182 \%$ e a usada $0,0242 \%$. A diferença entre as duas amostras é significativa e mostra que o fluido sem uso é mais tóxico que o usado. Neste caso, a utilização do fluido deve ter degradado alguns dos componentes responsáveis pela letalidade aos organismos usados neste estudo. Verifica-se ainda que para o fluido semi - sintético a toxicidade de ambas as amostras é muito menor quando comparada ao fluido mineral, em especial o usado.

As Tabelas 5.11 e 5.12 apresentam os resultados dos testes de 
toxicidade com sistema Microtox ${ }^{\circledR}$ para os fluidos sintéticos sem uso e usados.

Tabela 5.11 - Concentração letal a 50 \% dos indivíduos para a amostra C (fluido sintético sem uso).

\begin{tabular}{c|c|c|c|c}
\hline Teste & CE 50 (\%) & \multicolumn{2}{|l|}{ Intervalo de Confiança } & Fator de Confiança \\
\hline 1 & 0,0186 & 0,0180 & 0,0192 & 1,0748 \\
\hline 2 & 0,0197 & 0,0194 & 0,0200 & 1,1001 \\
\hline 3 & 0,0189 & 0,0185 & 0,0194 & 1,0564 \\
\hline 4 & 0,0194 & 0,0190 & 0,0198 & 1,1222 \\
\hline 5 & 0,0188 & 0,0184 & 0,0192 & 1,1181 \\
\hline Media & 0,0199 & 0,0195 & 0,0204 & 1,0986 \\
\hline
\end{tabular}

Tabela 5.12 - Concentração letal a $50 \%$ dos indivíduos para a amostra C' (fluido sintético usado).

\begin{tabular}{c|c|c|c|c}
\hline Teste & CE 50 (\%) & \multicolumn{2}{|c|}{ Intervalo de Confiança } & Fator de Confiança \\
\hline 1 & 0,0244 & 0,0238 & 0,0252 & 1,0941 \\
\hline 2 & 0,0269 & 0,0260 & 0,0276 & 1,1201 \\
\hline 3 & 0,0223 & 0,0216 & 0,0230 & 1,1408 \\
\hline 4 & 0,0234 & 0,0226 & 0,0240 & 1,1147 \\
\hline 5 & 0,0259 & 0,0250 & 0,0268 & 1,1742 \\
\hline Media & 0,0246 & 0,0238 & 0,0253 & 1,1288 \\
\hline
\end{tabular}

CE - concentração efetiva

Verifica-se pelos resultados, que o fluido sintético com base polimérica foi o que apresentou menor índice de toxicidade, com valor médio de $0,0199 \%$ e $0,0246 \%$ para as amostras C e C' respectivamente. O fluido usado demonstrou ser ligeiramente menos tóxico e susceptível a degradação pelo processo de usinagem, ou seja, tem seus compostos tóxicos degradados durante sua utilização. 
Ao analisar os resultados dos diferentes fluidos de usinagem, verifica-se que todos são considerados muito tóxicos de um modo geral. Entretanto, não foi possível fazer uma comparação dos valores apresentados pelos parâmetros físicos e químicos e a toxicidade as bactéria luminescente.

Apesar de se utilizar um organismo marinho para testar amostras com procedência de outros ambientes, o teste prevê a correção da salinidade em cada concentração utilizada no teste. Outro ponto discutível é a sensibilidade do fotômetro quando a amostra apresentar cor ou turbidez. As análises com amostras coloridas são feitas normalmente, com o devido protocolo e, posteriormente, se faz à correção dos cálculos com uso de outro protocolo específico para a correção da cor (MICROBICS, 1994).

A aplicabilidade do teste Microtox ${ }^{\circledR}$ bem como o crescente uso desse ensaio têm sido demonstrados pelos levantamentos bibliográficos e pela sua inclusão na $19^{a}$ edição do Standard Methods for the Examination of Water and Wastewater, de 1995. Além disso, boa correlação tem sido obtida por autores que compararam a sensibilidade entre organismos com a sensibilidade da bactéria $V$. fischeri (SANCHEZ E COL., 1989; ROWLEN, 1983; JUKTA \& KWAN, 1994).

A difícil tarefa de comparar diretamente resultados de avaliação da toxicidade entre as espécies é minimizada quando se trabalha com valores relativos. Para isso BULICH (1982) descreveu um método, mais tarde modificado por COLEMAN \& QUERESHI (1985), onde estabelecem faixas de toxicidade, conforme apresentado na Tabela 5.13. Outra possibilidade para comparar amostras avaliadas com o sistema Microtox ${ }^{\circledR}$ para amostras menos tóxicas foi estabelecida por RIBBO (1985), e utiliza o valor de efeito gama, conforme apresentada na Tabela 5.14. 
Tabela 5.13 - Sistema de classificação da toxicidade aguda, segundo BULICH (1982)

\begin{tabular}{c|c}
\hline \multicolumn{2}{c}{ GRAU DE TOXICIDADE } \\
\hline $\mathbf{C E}-\mathbf{5 0}(\%, \mathbf{v} / \mathbf{v})$ & Classificação \\
\hline$<25$ & Muito tóxica \\
\hline $25-50$ & Moderadamente tóxica \\
\hline $51-75$ & tóxica \\
\hline$>75$ & Levemente Tóxica \\
\hline
\end{tabular}

Tabela 5.14 - Classificação de toxicidade adotada a partir dos valores do efeito gama $(\Gamma)$.

\begin{tabular}{c|c|c|c|c}
\hline Valor Gama & $\% \Delta$ & Classe & Classificação & $\begin{array}{c}\text { No. de } \\
\text { amostras (\%) }\end{array}$ \\
\hline$\Gamma<0$ & $\Delta<5$ & $\circ$ & NT (") & $28(37 \%)$ \\
\hline $0<\Gamma<0,05$ & $\Delta<5$ & 1 & NT & $17(22 \%)$ \\
\hline $0,05<\Gamma<0,10$ & $5<\Delta<10$ & 2 & NT & $10(13 \%)$ \\
\hline $0,10<\Gamma<0,50$ & $10<\Delta<34,9$ & 3 & Baixa & $17(22 \%)$ \\
\hline $0,50<\Gamma<1,00$ & $35<\Delta<50$ & 4 & Média & 0 \\
\hline $1,00<\Gamma<10,00$ & $>50$ & 5 & Alta & $3(4 \%)$ \\
\hline$\Gamma>10,0$ & $>50$ & 6 & Alta & $1(1 \%)$ \\
\hline
\end{tabular}

$\left(^{*}\right)$ NT - não tóxica

Fonte: RIBO, 1995.

Segundo BORRELY (2001) a obtenção de dados através do sistema Microtox $^{\circledR}$ o qual é empregado no monitoramento da toxicidade de varias substâncias. Estes ensaios possibilitam a comparação dos dados da toxicidade efetiva, no entanto, não apresentam a caracterização química da água. 
A sensibilidade das bactérias usadas nos testes com o sistema Microtox ${ }^{\circledR}$ foi avaliada com uma solução da substância química fenol, a qual é referência neste tipo de ensaio. A concentração efetiva a 50\% dos indivíduos (CE $50 \%$ ) foi de $20,540 \% \pm 2,296 \%$ com coeficiente de variação para este conjunto de $11,17 \%$. Tais valores encontram-se dentro da faixa recomendada pela literatura (BERTOLETTI, 1992).

\subsubsection{Testes Agudos em amostras de fluidos de usinagem empregando- se Daphnias, família Daphnidae, Ordem Cladocera.}

Para a determinação da toxicidade dos fluidos empregando-se daphnideos, fez-se um estudo prévio das amostras. Monitorou-se $\mathrm{o} \mathrm{pH}$ e oxigênio dissolvido em ensaios preliminares. Verificou-se que com o efeito da diluição, o pH ficou em uma faixa de 7,2 e o oxigênio dissolvido em torno de 8 $\mathrm{mgL}^{-1}$. Ambos apresentaram estes valores em decorrência da diluição das amostras.

A seguir serão apresentados os resultados dos bioensaios para os daphnideos, Daphnia similis e Daphnia laevis.

\subsubsection{Daphnia similis}

Para esta espécie foram feitos 5 testes com as 6 amostras de fluido de usinagem. As Tabelas 5.15 a 5.20 apresentam os resultados obtidos nos testes feitos no período de janeiro a julho de 2005. Para as amostras A e A' e B e B' as concentrações utilizadas foram de $0,0005 \% ; 0,00025 \% ; 0,00010 \%$; $0,00005 \%$. Nas amostras sintéticas (C e C'), a faixa de concentração foi de 0,0020\%; 0,0010\%; 0,0005\%; 0,00025\%. 
Tabela 5.15 - Testes de toxicidade das amostras de fluido mineral sem uso (amostra A) a espécie Daphnia similis.

\begin{tabular}{c|c|c|c|c|c|c}
\hline Testes & \multicolumn{4}{|c|}{$\begin{array}{c}\text { Concentração/\% de } \\
\text { Efeito }\end{array}$} & CE \%, 48h & Efeito \\
\hline & 1 & 2 & 3 & 4 & & \\
\hline 1 & 100 & 70 & 40 & 20 & $\mathbf{0 , 0 0 0 6}(0,0005$ a 0,0009$)$ & $\mathrm{T}$ \\
\hline 2 & 100 & 60 & 25 & 0 & $\mathbf{0 , 0 0 0 5}(0,0004$ a 0,0007$)$ & $\mathrm{T}$ \\
\hline 3 & 90 & 80 & 30 & 15 & $\mathbf{0 , 0 0 0 8}(0,0006$ a 0,0010$)$ & $\mathrm{T}$ \\
\hline 4 & 100 & 60 & 25 & 15 & $\mathbf{0 , 0 0 0 7}(0,0005$ a 0,0009$)$ & $\mathrm{T}$ \\
\hline 5 & 90 & 70 & 30 & 15 & $\mathbf{0 , 0 0 1 1}(0,0009$ a 0,0014$)$ & $\mathrm{T}$ \\
\hline
\end{tabular}

T- tóxico

Tabela 5.16 - Testes de toxicidade das amostras de fluido mineral usado (amostra A') a espécie Daphnia similis..

\begin{tabular}{c|c|c|c|c|c|c}
\hline Testes & \multicolumn{4}{|c|}{ Concentração/\% de } & CE \%, 48h & Efeito \\
\hline & 1 & 2 & 3 & 4 & & \\
\hline 1 & 100 & 60 & 35 & 15 & $\mathbf{0 , 0 0 0 4}(0,0003$ a 0,0006) & T \\
\hline 2 & 100 & 75 & 40 & 25 & $\mathbf{0 , 0 0 0 5}(0,0004$ a 0,0007$)$ & $\mathrm{T}$ \\
\hline 3 & 95 & 70 & 40 & 20 & $\mathbf{0 , 0 0 0 7}(0,0005$ a 0,0009$)$ & $\mathrm{T}$ \\
\hline 4 & 90 & 80 & 30 & 20 & $\mathbf{0 , 0 0 0 5}(0,0004$ a 0,0007$)$ & $\mathrm{T}$ \\
\hline 5 & 95 & 60 & 35 & 15 & $\mathbf{0 , 0 0 0 6}(0,0004$ a 0,0008$)$ & $\mathrm{T}$ \\
\hline
\end{tabular}

T - tóxico

Verifica-se pelos resultados apresentados nas tabelas 5.15 e 5.16 que o fluido mineral foi altamente tóxico para a espécie utilizada neste ensaio, apresentando uma CE \% em torno de 0,0007 \% da amostra bruta. As Figuras 5.1 e 5.2. apresentam os resultados dos testes de toxicidade para as amostras de fluidos de usinagem mineral frente à espécie Daphnia similis. 


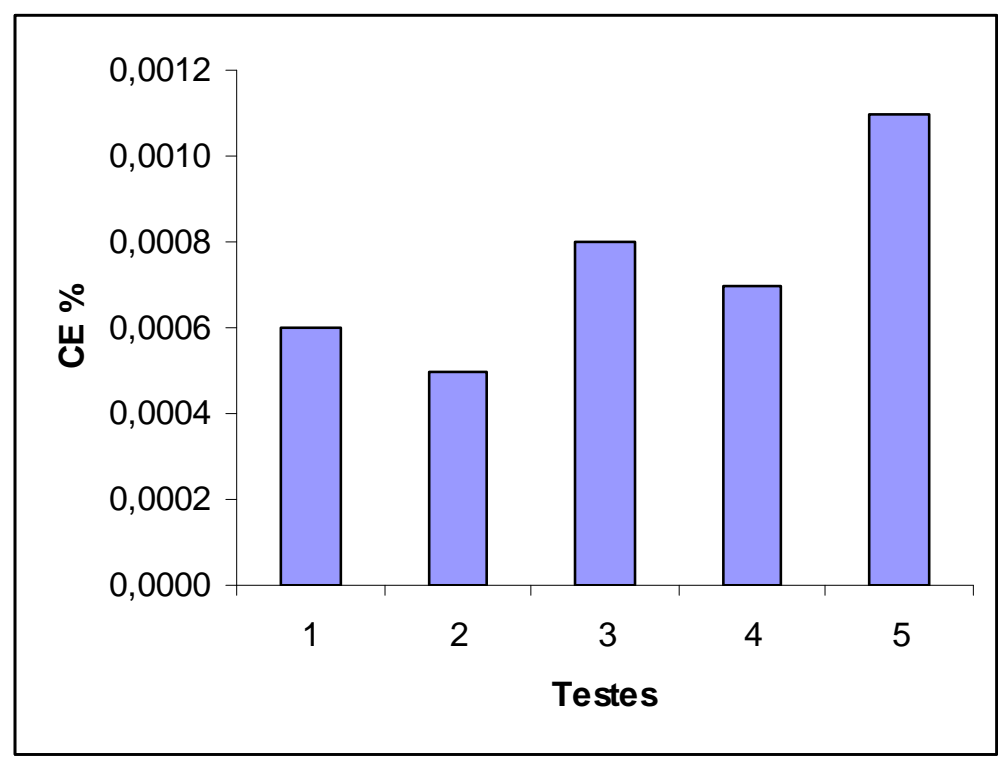

Figura 5.1. - Resultados da toxicidade da amostra de fluido mineral sem uso (A) a espécie Daphnia similis.

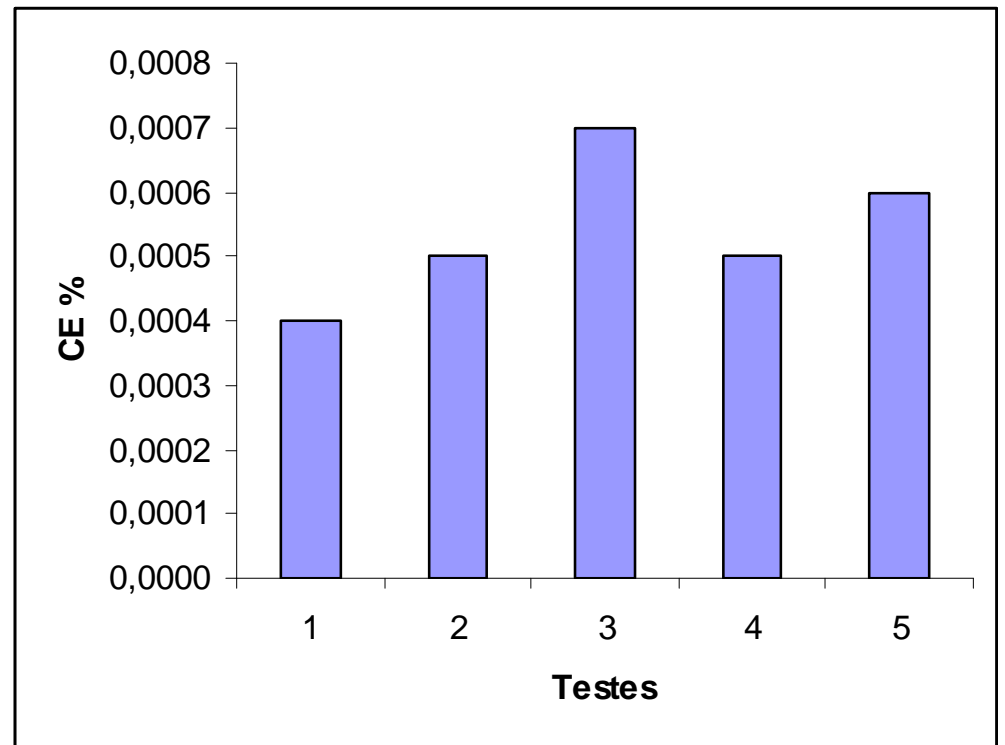

Figura 5.2. - Resultados da toxicidade da amostra de fluido mineral usado (A') a espécie Daphnia similis.

As Figuras 5.1 e 5.2 mostram que houve uma pequena diferença entre a amostra nova e usada, sendo a segunda mais tóxica, provavelmente pela formação ou degradação de alguma substância presente no fluido. De qualquer 
forma, ambas apresentaram concentração letal em torno de 0,00010 \% do fluido, ou seja, uma pequena quantidade deste material poderia poluir uma grande área de um recurso hídrico.

Tabela 5.17 - Testes de toxicidade das amostras de fluido semi-sintético sem uso (amostra B) a espécie Daphnia similis.

\begin{tabular}{c|c|c|c|c|c|c}
\hline Testes & \multicolumn{4}{|c|}{ Concentração/\% de } & CE \%, 48h & Efeito \\
\hline & 1 & 2 & 3 & 4 & & \\
\hline 1 & 95 & 65 & 35 & 15 & $\mathbf{0 , 0 0 1 2}(0,0010$ a 0,0014) & T \\
\hline 2 & 100 & 65 & 25 & 15 & $\mathbf{0 , 0 0 1 0}(0,0008$ a 0,0012) & T \\
\hline 3 & 90 & 65 & 30 & 20 & $\mathbf{0 , 0 0 1 1}(0,0009$ a 0,0014) & T \\
\hline 4 & 90 & 75 & 35 & 20 & $\mathbf{0 , 0 0 1 5}(0,0013$ a 0,0017$)$ & T \\
\hline 5 & 95 & 60 & 25 & 15 & $\mathbf{0 , 0 0 1 3}(0,0015$ a 0,0017$)$ & T \\
\hline
\end{tabular}

T - tóxico

Tabela 5.18 - Testes de toxicidade das amostras de fluido semi-sintético usado (amostra B') a espécie Daphnia similis.

\begin{tabular}{c|c|c|c|c|c|c}
\hline Testes & \multicolumn{4}{|c|}{ Concentração/\% de } & CE \%, 48h & Efeito \\
\hline & 1 & 2 & 3 & 4 & & \\
\hline 1 & 100 & 75 & 40 & 15 & $\mathbf{0 , 0 0 1 6}(0,0014$ a 0,0019) & T \\
\hline 2 & 90 & 75 & 30 & 15 & $\mathbf{0 , 0 0 1 9}(0,0016$ a 0,0021) & T \\
\hline 3 & 90 & 70 & 30 & 15 & $\mathbf{0 , 0 0 1 5}(0,0013$ a 0,0017) & T \\
\hline 4 & 95 & 75 & 30 & 15 & $\mathbf{0 , 0 0 1 7}(0,0015$ a 0,0019$)$ & T \\
\hline 5 & 90 & 70 & 30 & 10 & $\mathbf{0 , 0 0 1 5}(0,0013$ a 0,0017$)$ & T \\
\hline
\end{tabular}

T - tóxico

Observa-se que a amostra de fluido, semi-sintético, a amostra nova foi a mais tóxica, diferentemente do fluido mineral. Entretanto, os organismos foram menos sensíveis a esta substância (Figuras 5.3 e 5.4). Os resultados foram muito similares e a CE $50 \%$ média para os fluidos foi de $0,0015 \%$ da amostra sem diluições. 


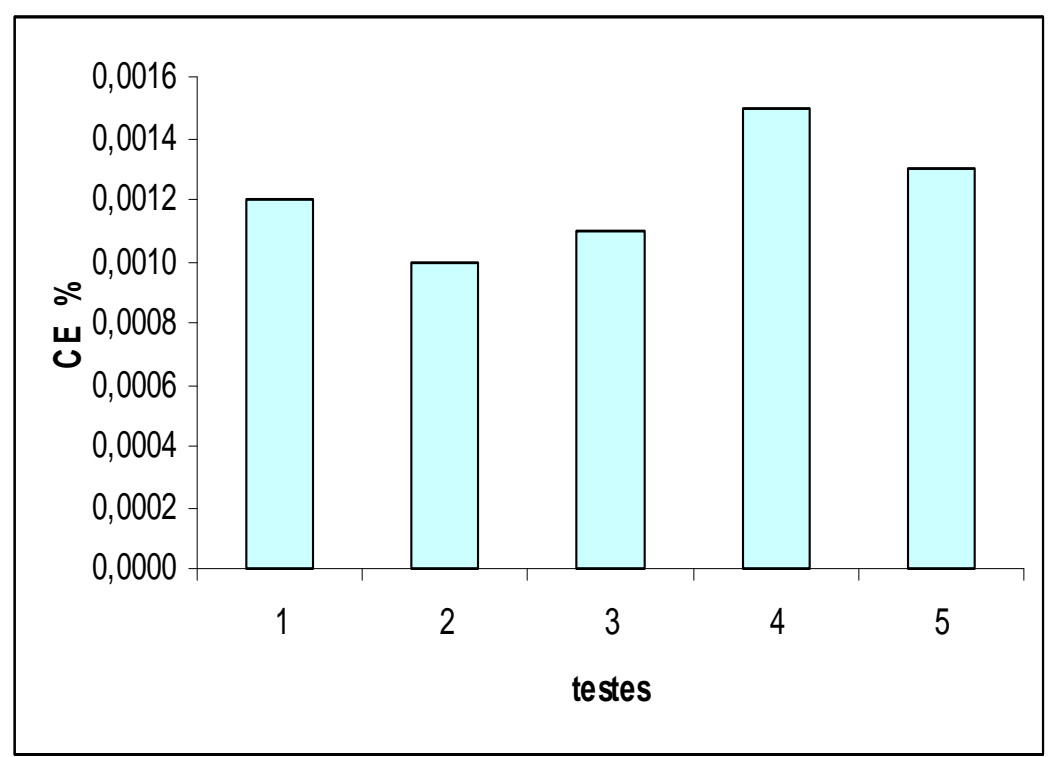

Figura 5.3. - Resultados da toxicidade da amostra de fluido semi-sintético sem uso (B) a espécie Daphnia similis.

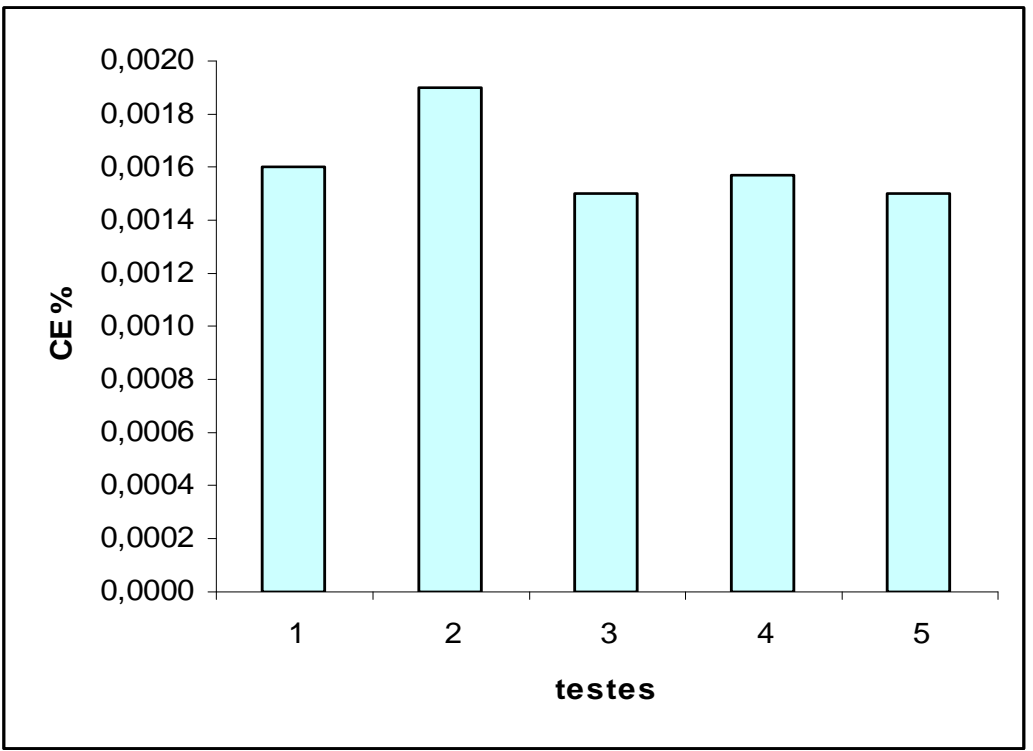

Figura 5.4. - Resultados da toxicidade da amostra de fluido semi-sintético usado (B') a espécie Daphnia similis.

Observa-se de pelas Figuras 5.3 e 5.4 que o fluido usado (B') apresentou menor coeficiente de variação e sua toxicidade foi reduzida pelo 
uso provavelmente em decorrência da degradação de algum composto tóxico presente em sua composição ao longo do processo de usinagem.

Tabela 5.19 - Testes de toxicidade das amostras de fluido sintético sem uso (amostra C) a espécie Daphnia similis.

\begin{tabular}{c|c|c|c|c|c|c}
\hline Testes & \multicolumn{4}{|c|}{ Concentração/\% de } & CE \%, 48h & Efeito \\
\hline & 1 & 2 & 3 & 4 & & \\
\hline 1 & 95 & 70 & 35 & 20 & $\mathbf{0 , 0 0 2}(0,001$ a 0,003$)$ & $\mathrm{T}$ \\
\hline 2 & 85 & 60 & 25 & 15 & $\mathbf{0 , 0 0 3}(0,004$ a 0,005$)$ & $\mathrm{T}$ \\
\hline 3 & 90 & 70 & 30 & 15 & $\mathbf{0 , 0 0 3}(0,002$ a 0,004$)$ & $\mathrm{T}$ \\
\hline 4 & 100 & 60 & 40 & 20 & $\mathbf{0 , 0 0 4}(0,003$ a 0,005$)$ & $\mathrm{T}$ \\
\hline 5 & 95 & 65 & 25 & 15 & $\mathbf{0 , 0 0 2}(0,001$ a 0,003$)$ & $\mathrm{T}$ \\
\hline
\end{tabular}

T - tóxico

Tabela 5.20 - Testes de toxicidade das amostras de fluido sintético usado (amostra C') a espécie Daphnia similis.

\begin{tabular}{c|c|c|c|c|c|c}
\hline Testes & \multicolumn{4}{|c|}{ Concentração/\% de } & CE \%, 48h & Efeito \\
\hline & 1 & 2 & 3 & 4 & & \\
\hline 1 & 95 & 70 & 45 & 20 & $\mathbf{0 , 0 0 1 0}(0,001$ a 0,003$)$ & $\mathrm{T}$ \\
\hline 2 & 90 & 65 & 25 & 10 & $\mathbf{0 , 0 0 1 5}(0,004$ a 0,005$)$ & $\mathrm{T}$ \\
\hline 3 & 100 & 80 & 30 & 15 & $\mathbf{0 , 0 0 0 8}(0,002$ a 0,004$)$ & $\mathrm{T}$ \\
\hline 4 & 90 & 75 & 25 & 10 & $\mathbf{0 , 0 0 1 6}(0,003$ a 0,005$)$ & $\mathrm{T}$ \\
\hline 5 & 95 & 70 & 25 & 15 & $\mathbf{0 , 0 0 1 2}(0,001$ a 0,003$)$ & $\mathrm{T}$ \\
\hline
\end{tabular}

T - tóxico

Observa-se que o fluido sintético sem uso foi menos tóxico que o usado. Os resultados foram bem similares aos apresentados pelos testes com a bactéria luminescente Vibrio fischeri, ou seja, dentre as amostras de fluido, esta foi a que apresentou menor toxicidade (Figuras 5.5 e 5.6). 


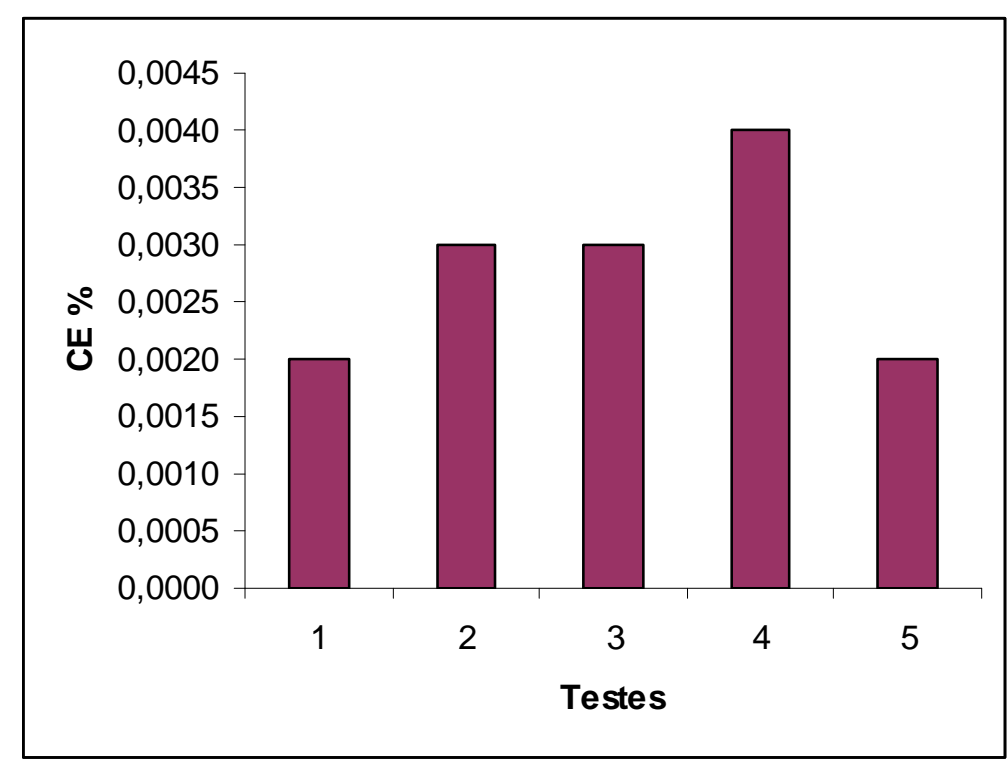

Figura 5.5. - Resultados da toxicidade da amostra de fluido sintético sem uso (C) a espécie Daphnia similis.

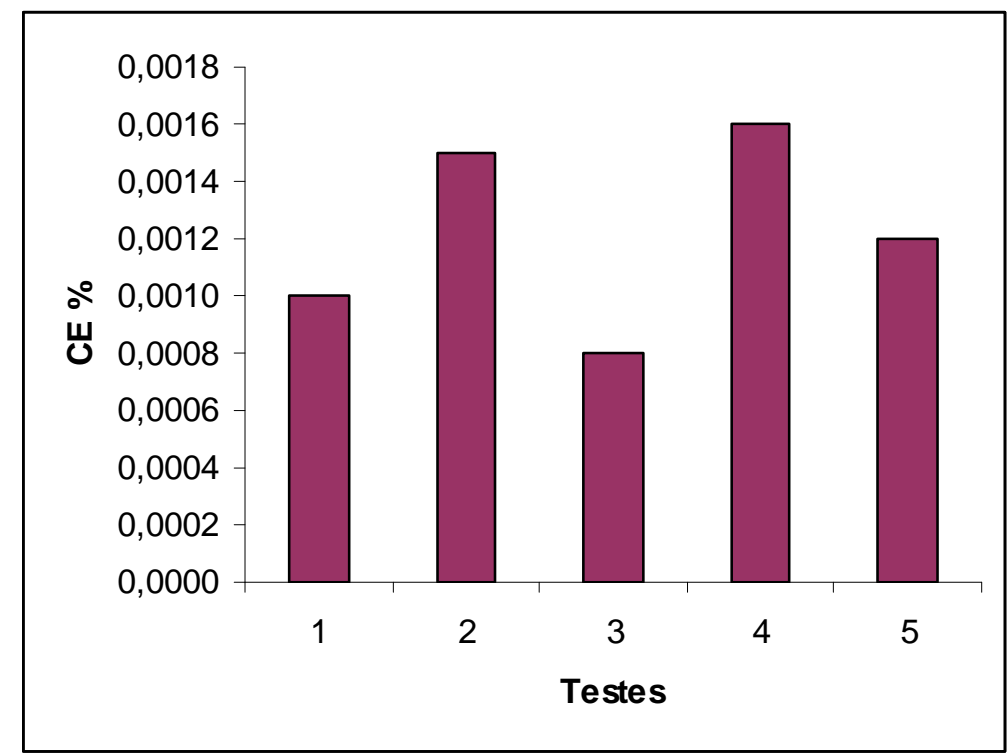

Figura 5.6. - Resultados da toxicidade da amostra de fluido sintético usado (C') a espécie Daphnia similis.

Verificou-se pelos resultados apresentados nas Figuras 5.5 e 5.6 que o fluido sintético, sem uso e usado, apresentam uma grande distinção na toxicidade, pois a amostra usada possui praticamente o dobro da toxicidade da nova. 
Os resultados apresentados anteriormente, mostram que existe uma grande diferença entre a toxicidade das amostras dos fluidos. Os fluidos minerais são muito tóxicos e praticamente não existe diferença entre a amostra sem uso e a usada, apresentando a segunda uma letalidade ligeiramente maior aos organismos. As amostras semi-sintéticas apresentam resultados distintos, sendo a amostra sem uso mais tóxica que a usada. Isto indica que, durante a operação de usinagem de peças metálicas pode ter ocorrido a degradação de algum composto responsável pela morte dos organismos. Para as demais amostras, poliméricas, este efeito ocorrem de forma contraria, ou seja, a amostra sem uso é menos tóxica e há a formação de um composto mais agressivo aos organismos aquáticos.

Os testes de toxicidade empregando Daphnia similis indicam que as amostras de fluido de usinagem de peças metálicas apresentam efeitos agudos tanto as sem uso como as usadas. Os dados obtidos mostram que não existe degradação das substâncias tóxicas ao longo da utilização deste material na usinagem de peças metálicas.

Possivelmente, a toxicidade aguda dos fluidos esta associada a compostos adicionados aos mesmos para melhor atender aos requisitos da indústria. Segundo AMARANTE JR (2003) deve-se entender que a degradação destes fluidos não pode ser estudada como um sistema de um único constituinte, isto porque a complexidade dessa matriz deve ser considerada, pois existe uma superposição de efeitos e fenômenos, aumentando as variáveis a serem investigadas (NOCENTINI et al., 2000). 


\subsubsection{Daphnia laevis}

As Tabelas 5.21 a 5.26 apresentam os resultados dos testes de toxicidade feitos com Daphnia laevis nas amostras de fluidos de usinagem no período de fevereiro a agosto de 2005. Durante os testes preliminares, verificou-se que esta espécie é mais sensível quando comparada a D. similis. Desta forma, as concentrações empregadas nos ensaios foram às mesmas para todas as amostras, ou seja, 0,0005\%; 0,00025\%; 0,00010\% e 0,00005\% respectivamente.

Tabela 5.21 - Testes de toxicidade das amostras de fluido mineral sem uso (amostra A) para a espécie Daphnia laevis.

\begin{tabular}{c|c|c|c|c|c|c}
\hline Testes & \multicolumn{4}{|c|}{ Concentração/\% de } & CE \%, 48h & Efeito \\
\hline & 1 & 2 & 3 & 4 & & \\
\hline 1 & 95 & 70 & 35 & 15 & $\mathbf{0 , 0 0 0 4}(0,0002$ a 0,0006$)$ & $\mathrm{T}$ \\
\hline 2 & 95 & 75 & 30 & 10 & $\mathbf{0 , 0 0 0 5}(0,0003$ a 0,0007$)$ & $\mathrm{T}$ \\
\hline 3 & 90 & 65 & 30 & 15 & $\mathbf{0 , 0 0 0 3}(0,0002$ a 0,0004$)$ & $\mathrm{T}$ \\
\hline 4 & 100 & 65 & 25 & 10 & $\mathbf{0 , 0 0 0 3}(0,0002$ a 0,0004$)$ & $\mathrm{T}$ \\
\hline 5 & 95 & 70 & 25 & 15 & $\mathbf{0 , 0 0 0 4}(0,0003$ a 0,0006$)$ & $\mathrm{T}$ \\
\hline
\end{tabular}

T - Tóxico

Tabela 5. 22 - Testes de toxicidade das amostras de fluido mineral usada (amostra A') para a espécie Daphnia laevis.

\begin{tabular}{c|c|c|c|c|c|c}
\hline Testes & \multicolumn{4}{|c|}{ Concentração/\% de } & CE \%, 48h & Efeito \\
\hline & 1 & 2 & 3 & 4 & & \\
\hline 1 & 90 & 60 & 35 & 20 & $\mathbf{0 , 0 0 0 3}(0,0002$ a 0,0004) & $\mathrm{T}$ \\
\hline 2 & 95 & 70 & 40 & 20 & $\mathbf{0 , 0 0 0 5}(0,0004$ a 0,0006$)$ & $\mathrm{T}$ \\
\hline 3 & 95 & 65 & 35 & 15 & $\mathbf{0 , 0 0 0 4}(0,0002$ a 0,0006$)$ & $\mathrm{T}$ \\
\hline 4 & 95 & 65 & 30 & 10 & $\mathbf{0 , 0 0 0 3}(0,0002$ a 0,0005$)$ & $\mathrm{T}$ \\
\hline 5 & 95 & 60 & 35 & 15 & $\mathbf{0 , 0 0 0 2}(0,0001$ a 0,0003$)$ & $\mathrm{T}$ \\
\hline
\end{tabular}

T - Tóxico

Os resultados apresentados nas Tabelas 5.21 e 5.22 indicam que esta 
espécie é bem sensível ao fluido mineral, sem uso e usado. Os valores estão bem próximos indicando que não ocorrem diferenças significativas quando do uso deste fluido na usinagem de peças metálicas.

As Figuras 5.7 e 5.8 apresentam os resultados dos testes de toxicidade para as amostras de fluido mineral (A e A') para a espécie de microcrustáceo, Daphnia laevis.

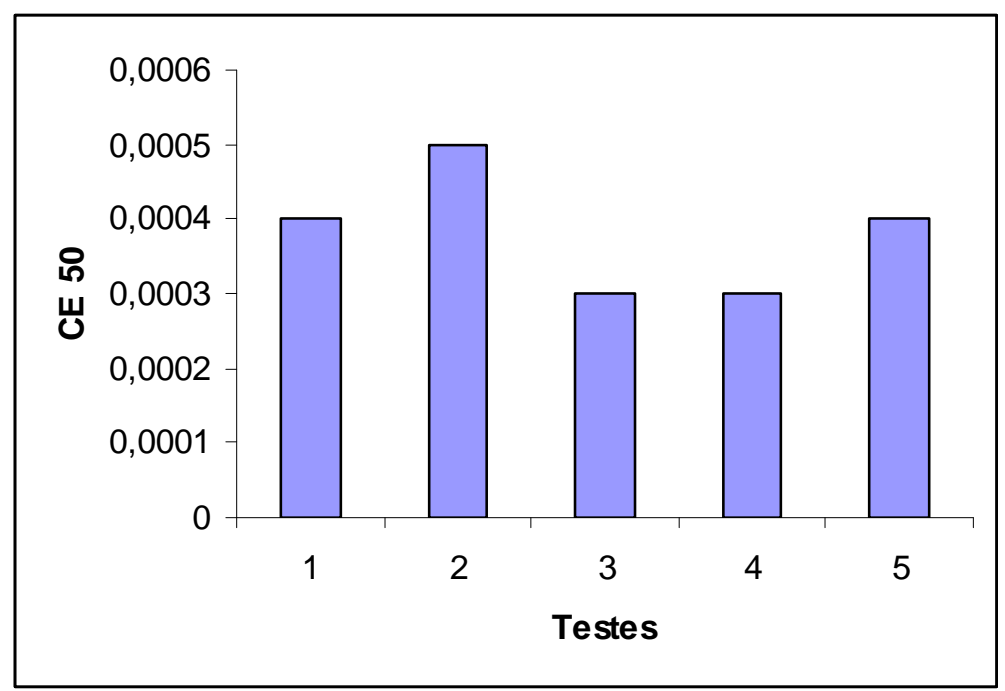

Figura 5.7. - Resultados da toxicidade da amostra de fluido mineral sem uso (A) para a espécie Daphnia laevis.

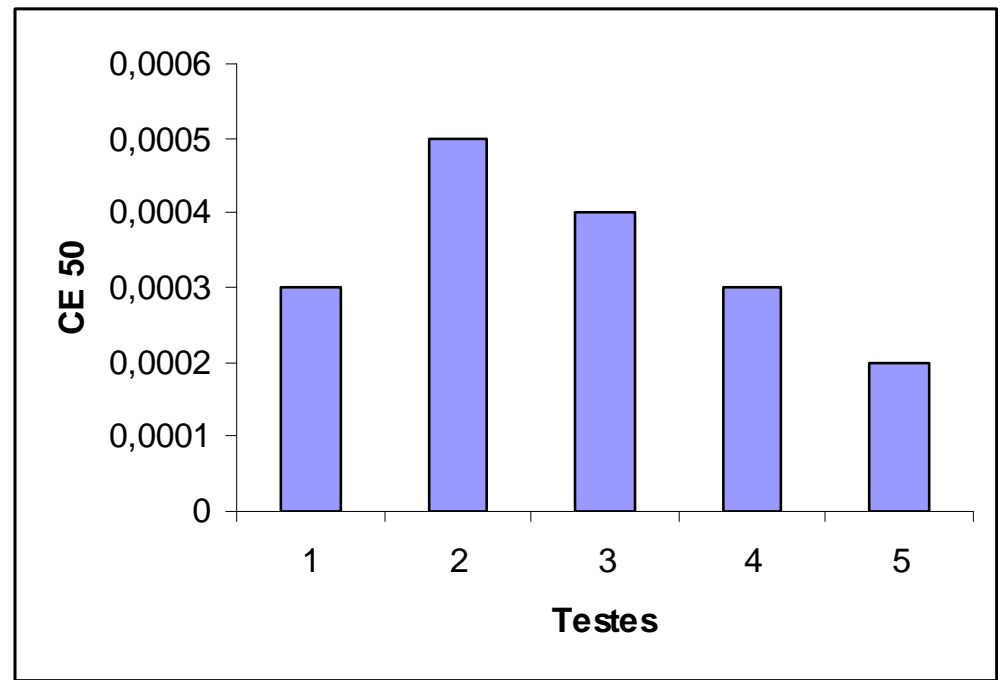

Figura 5.8. - Resultados da toxicidade da amostra de fluido mineral usado (A') para a espécie Daphnia laevis. 
Verifica-se pelas Figuras 5.7 e 5.8 que houve maior toxicidade na amostra de fluido usada, indicando que a mesma pode apresentar compostos com maior toxicidade em decorrência de seu uso na usinagem de peças metálicas.

Tabela 5. 23 - Testes de toxicidade das amostras de fluido semi-sintética sem uso (amostra B) para a espécie Daphnia laevis.

\begin{tabular}{c|c|c|c|c|c|c}
\hline Testes & \multicolumn{4}{|c|}{$\begin{array}{c}\text { Concentração/\% de } \\
\text { Efeito }\end{array}$} & CE \%, 48h & \\
\hline & 1 & 2 & 3 & 4 & & \\
\hline 1 & 100 & 70 & 35 & 15 & $\mathbf{0 , 0 0 0 9}(0,0007$ a 0,0011$)$ & $\mathrm{T}$ \\
\hline 2 & 95 & 65 & 25 & 15 & $\mathbf{0 , 0 0 0 8}(0,0008$ a 0,0012$)$ & $\mathrm{T}$ \\
\hline 3 & 90 & 60 & 30 & 10 & $\mathbf{0 , 0 0 0 7}(0,0006$ a 0,0008$)$ & $\mathrm{T}$ \\
\hline 4 & 100 & 75 & 35 & 20 & $\mathbf{0 , 0 0 0 9}(0,0008$ a 0,0011$)$ & $\mathrm{T}$ \\
\hline 5 & 95 & 60 & 25 & 15 & $\mathbf{0 , 0 0 0 7}(0,0006$ a 0,0008$)$ & $\mathrm{T}$ \\
\hline
\end{tabular}

T - Tóxico

Tabela 5. 24 - Testes de toxicidade das amostras de fluido semi-sintética usada (amostra B') para a espécie Daphnia laevis.

\begin{tabular}{c|c|c|c|c|c|c}
\hline Testes & \multicolumn{4}{|c|}{ Concentração/\% de } & CE \%, 48h & Efeito \\
& 1 & 2 & 3 & 4 & & \\
\hline 1 & 100 & 75 & 40 & 15 & $\mathbf{0 , 0 0 1 0}(0,0008$ a 0,0012) & $\mathrm{T}$ \\
\hline 2 & 90 & 60 & 30 & 10 & $\mathbf{0 , 0 0 0 8}(0,0006$ a 0,0010$)$ & $\mathrm{T}$ \\
\hline 3 & 90 & 70 & 30 & 15 & $\mathbf{0 , 0 0 0 6}(0,0004$ a 0,0008$)$ & $\mathrm{T}$ \\
\hline 4 & 95 & 75 & 30 & 15 & $\mathbf{0 , 0 0 1 0}(0,0008$ a 0,0012$)$ & $\mathrm{T}$ \\
\hline 5 & 90 & 65 & 30 & 10 & $\mathbf{0 , 0 0 0 7}(0,0005$ a 0,0009$)$ & $\mathrm{T}$ \\
\hline
\end{tabular}

T - Tóxico

Para os fluidos semi-sintéticos ( $B$ e $B^{\prime}$ ), também houve grande similaridade entre a amostra sem uso e usada. Contudo, verfica-se pelos valores da CE 50 que este fluido apresenta-se menos tóxico a $D$. laevis quando comparado à amostra mineral (Figuras 5.9 e 5.10). 


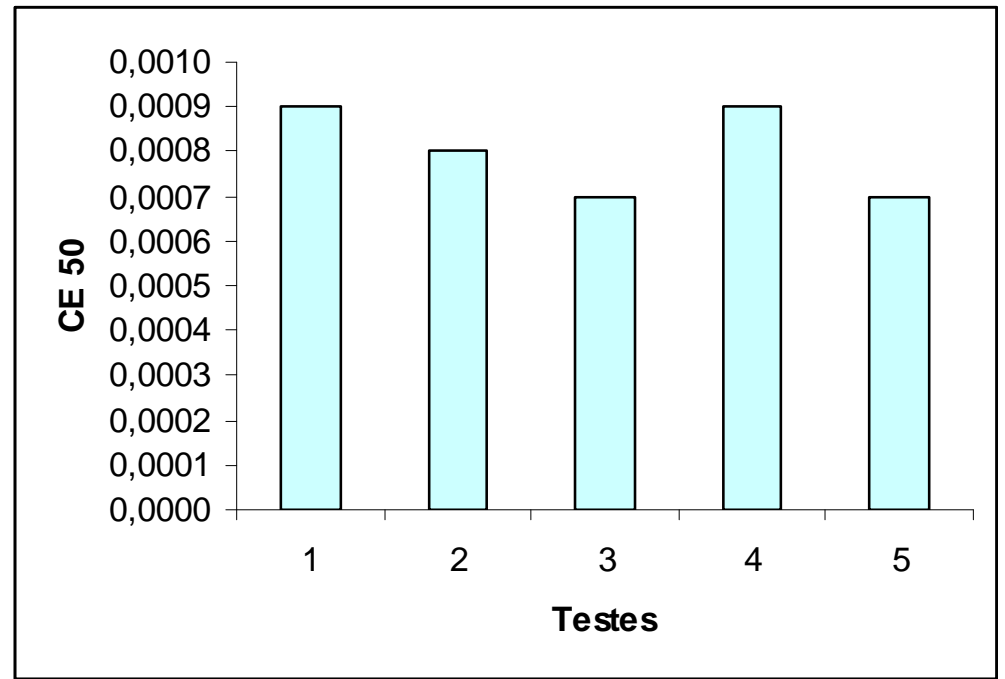

Figura 5.9. - Resultados da toxicidade da amostra de fluido semi-sintético sem uso (B) para a espécie Daphnia laevis.

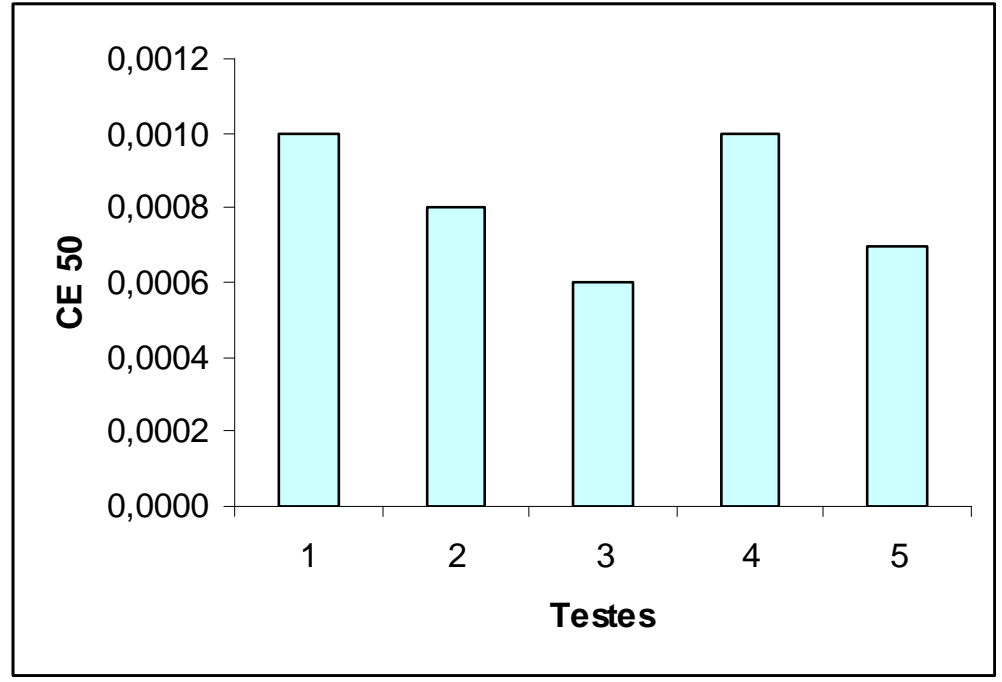

Figura 5.10. - Resultados da toxicidade da amostra de fluido semi-sintético usado (B') para a espécie Daphnia laevis.

Os resultados da toxicidade dos fluidos apresentados nas Figuras 5.9 e 5.10 mostram que a amostra sem uso foi ligeiramente menos tóxica que a 
usada, possivelmente em decorrência da degradação durante o seu uso na usinagem industrial de peças metálicas.

Tabela 5. 25 - Testes de toxicidade das amostras de fluido sintética sem uso (amostra C) para a espécie Daphnia laevis.

\begin{tabular}{c|c|c|c|c|c|c}
\hline Testes & \multicolumn{4}{|c|}{ Concentração/\% de } & CE \%, 48h & Efeito \\
\hline & 1 & 2 & 3 & 4 & & \\
\hline 1 & 95 & 70 & 35 & 20 & $\mathbf{0 , 0 0 0 8}(0,0006$ a 0,0010) & T \\
\hline 2 & 85 & 60 & 25 & 15 & $\mathbf{0 , 0 0 0 7}(0,0005$ a 0,0009$)$ & $\mathrm{T}$ \\
\hline 3 & 90 & 65 & 30 & 15 & $\mathbf{0 , 0 0 0 8}(0,0006$ a 0,0010$)$ & $\mathrm{T}$ \\
\hline 4 & 90 & 60 & 40 & 20 & $\mathbf{0 , 0 0 0 9}(0,0007$ a 0,0009$)$ & $\mathrm{T}$ \\
\hline 5 & 100 & 65 & 30 & 15 & $\mathbf{0 , 0 0 1 0}(0,0008$ a 0,0012$)$ & $\mathrm{T}$ \\
\hline
\end{tabular}

T - Tóxico

Tabela 5.26 - Testes de toxicidade das amostras de fluido sintética usada (amostra C') para a espécie Daphnia laevis

\begin{tabular}{c|c|c|c|c|c|c}
\hline Testes & \multicolumn{4}{|c|}{ Concentração/\% de } & CE \%, 48h & Efeito \\
& 1 & 2 & 3 & 4 & & \\
\hline 1 & 95 & 70 & 45 & 20 & $\mathbf{0 , 0 0 1 0}(0,0008$ a 0,0012) & T \\
\hline 2 & 90 & 65 & 25 & 10 & $\mathbf{0 , 0 0 0 8}(0,0006$ a 0,0010) & $\mathrm{T}$ \\
\hline 3 & 100 & 80 & 30 & 15 & $\mathbf{0 , 0 0 0 8}(0,0006$ a 0,0010) & $\mathrm{T}$ \\
\hline 4 & 90 & 75 & 25 & 10 & $\mathbf{0 , 0 0 0 9}(0,0007$ a 0,0011) & $\mathrm{T}$ \\
\hline 5 & 95 & 70 & 25 & 15 & $\mathbf{0 , 0 0 0 7}(0,0005$ a 0,0009) & $\mathrm{T}$ \\
\hline
\end{tabular}

T - Tóxico

Os resultados apresentados nas Tabelas 5.25 e 5.26 indicam que 0 fluido sintético (C e C') provoca alto índice de mortandade à espécie D.laevis. Os valores da CE 50 estão bem próximos indicando que não ocorrem diferenças significativas quando do uso deste fluido na usinagem de peças metálicas. 
As Figuras 5.11 e 5.12 apresentam os resultados dos testes de toxicidade para as amostras de fluido sintético para a espécie Daphnia laevis.

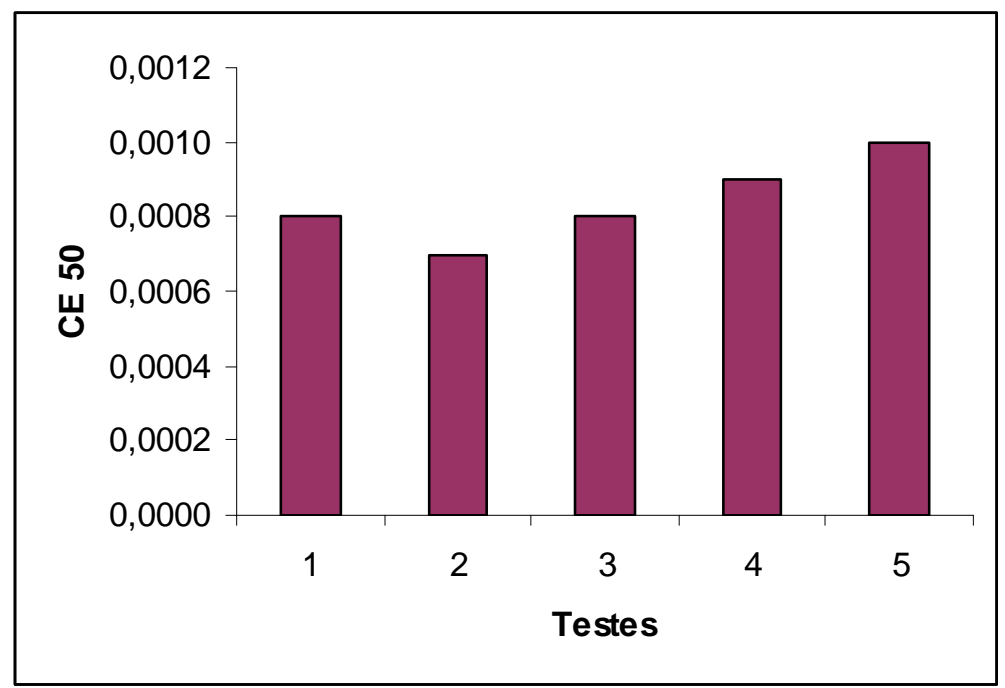

Figura 5.11. - Resultados da toxicidade da amostra de fluido sintético sem uso (C) para a espécie Daphnia laevis.

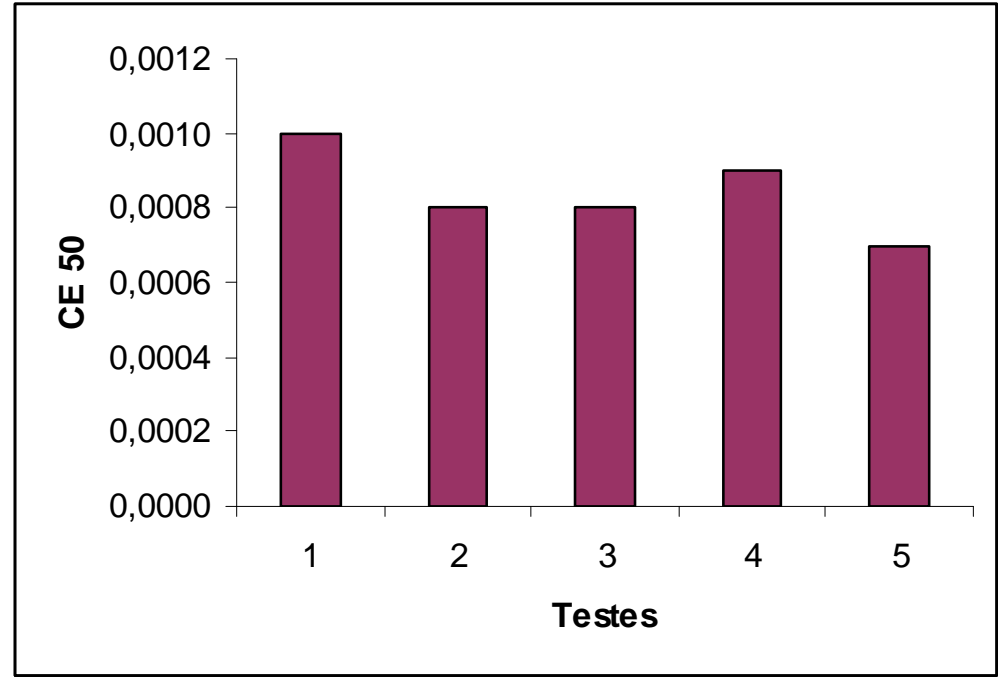

Figura 5.12. - Resultados da toxicidade da amostra de fluido sintético usado (C') para a espécie Daphnia laevis.

Pode-se verificar que pelos resultados apresentados nas Figuras 5.11 e 5.12 , os fluidos de base poliméricas (sintéticos) apresentam toxicidade 
aguda para a espécie $D$. laevis com uma concentração letal média a $50 \%$ da população de $0,0008 \%$ do fluido bruto.

Os bioensaios demonstram que todas as amostras de fluido estudados apresentaram toxicidade aguda para a espécie D. laevis. Contudo, a faixa de concentração efetiva (CE 50\%) foi similar para os fluidos semi-sintético e sintético, enquanto o fluido mineral apresentou maior toxicidade que as demais.

Nestes ensaios, observou-se que a D. laevis por ter um tamanho menor que a $D$. similis, apresentaram maiores problemas quanto à natação. Isto porque as amostras formam um filme muito fino na superfície do líquido o qual aprisiona os organismos fazendo com que os mesmos fiquem estáticos nas paredes do tubo de ensaio. Este fato levou a uma certa dificuldade na leitura do teste, pois suspeitava-se que os neonatos estivessem mortos, mas após leve agitação dos tubos, verificou-se que os organismos estavam imobilizados.

Pode ser que os efeitos destas substâncias na natureza iriam permanecer até a morte desta comunidade, pois se o organismo perde a imobilidade isso o impossibilita de se alimentar ou fugir de predadores.

Estudos com espécies nativas do Brasil ainda são muito recentes e escassos. Desta forma, a comparação entre resultados com o mesmo tipo de amostra torna-se impraticável.

\subsubsection{Testes de sensibilidade para os organismos usados nos testes}

Fez-se testes com as substâncias referência dicromato de potássio e cloreto de sódio para melhor avaliar as condições de saúde dos organismos. Isto porque a literatura apresenta uma série de resultados empregando-se dicromato de potássio, contudo, esta substância reconhecidamente tóxica, vem 
tendo seu uso reduzido, como no caso das análises de DQO, ou completamente substituída, como nos testes de sensibilidade.

\subsection{Testes de sensibilidade com dicromato de potássio $\left(\mathrm{K}_{2} \mathrm{Cr}_{2} \mathrm{O}_{7}\right)$}

A CETESB (1991) estabeleceu uma faixa de sensibilidade para $D$. similis empregando o dicromato de potássio na concentração de 0,040 a 0,176 mg L-1. Neste estudo, obteve-se para este mesmo organismo um resultado de sensibilidade com concentração de 0,052-0,169 $\mathrm{mg} \mathrm{L}^{-1}$. Para $D$. laevis as concentrações obtidas foram de $0,047-0,0126 \mathrm{mg} \mathrm{L}^{-1}$.

Os resultados dos testes de sensibilidade para $D$. similis e $D$. laevis são apresentados nas Figuras 5.13 e 5.14 e nas Tabelas 5.27 e 5.28. Verifica-se que as espécies cultivadas apresentam sensibilidade semelhantes à substância de referência. Isto pode ser inferido pela ocorrência do mesmo número de mudas durante o período em que foram expostas, já que o comprimento do corpo dos organismos foi igual para as 48 horas de exposição. Quando ocorre a muda o organismo se torna mais suscetível a substância por estar mais sensível. 


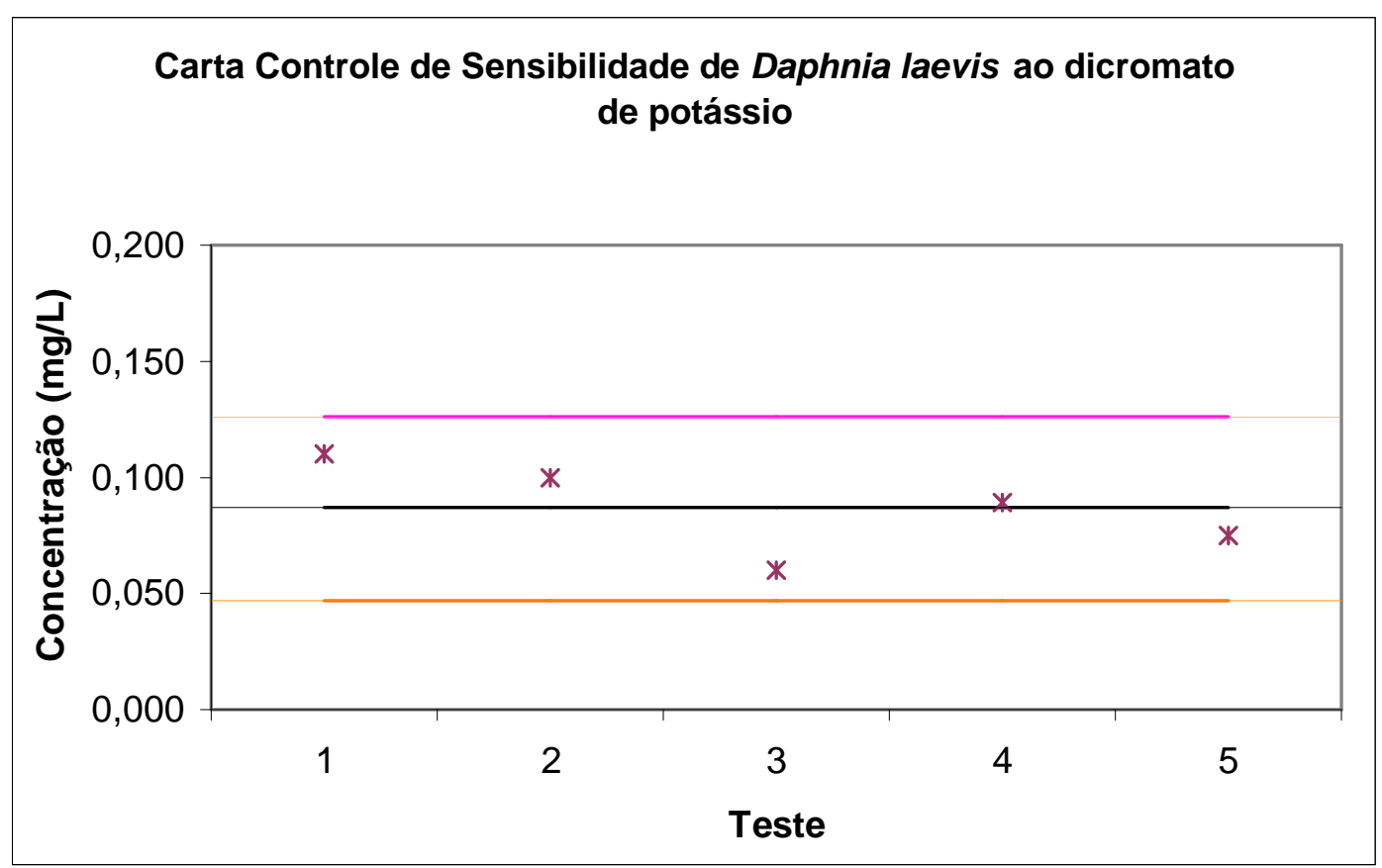

Figura 5.13 - Sensibilidade de Daphnia laevis ao dicromato de potássio.

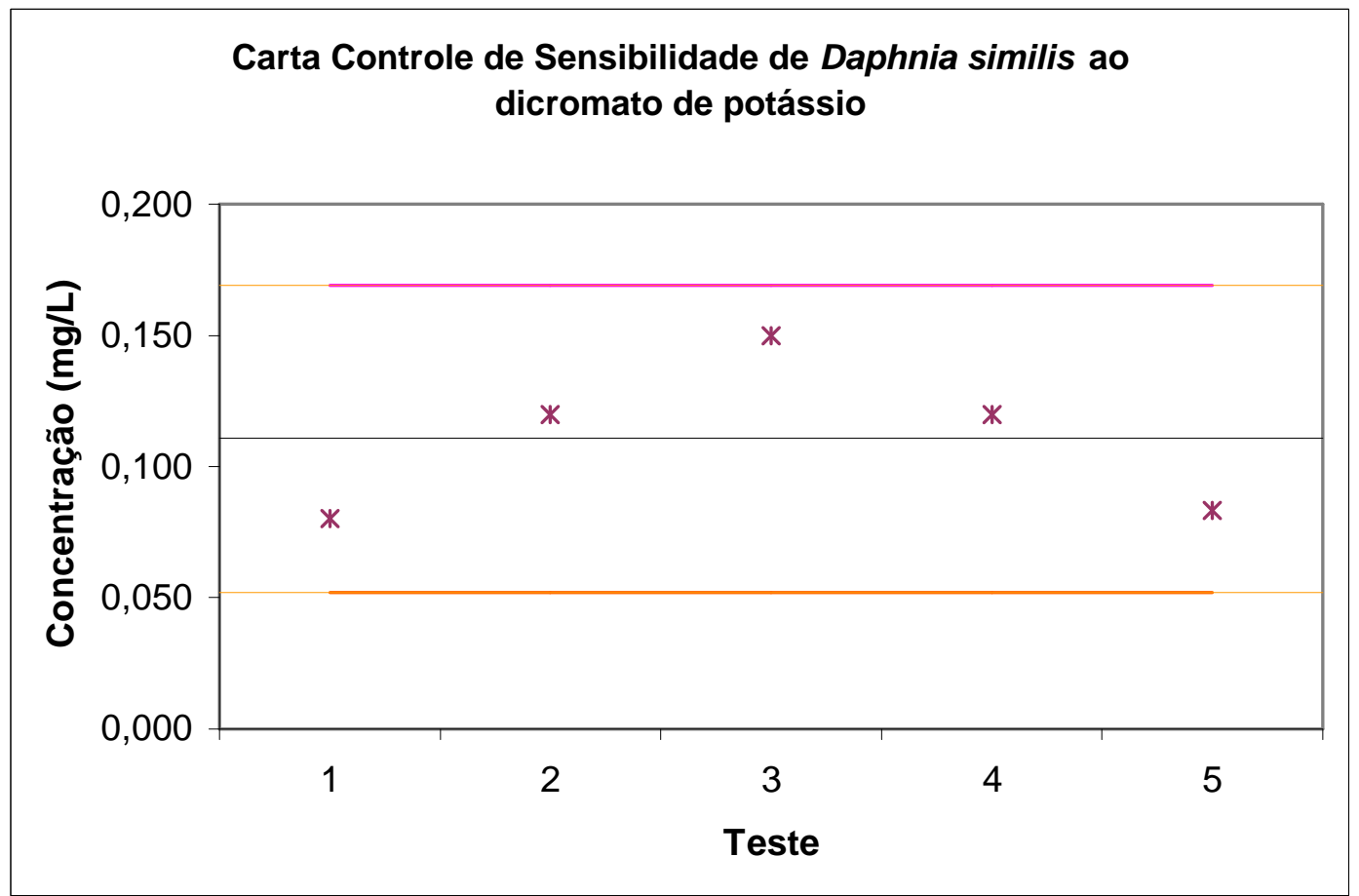

Figura 5.14 - Sensibilidade de Daphnia similis ao dicromato de potássio. 
Tabela 5.27 - Sensibilidade de D. laevis ao Dicromato de Potássio.

\begin{tabular}{ccc|}
\hline \multicolumn{3}{c|}{ Daphnia laevis } \\
\hline Teste & $\mathbf{C E}(\mathbf{I}) \mathbf{5 0}\left(\mathbf{m g ~ L}^{-1}\right)$ & Intervalo de confiança $\left(\mathbf{m g ~ L}^{-1}\right)$ \\
\hline 1 & 0,110 & $0,100-0,120$ \\
2 & 0,100 & $0,080-0,120$ \\
3 & 0,060 & $0,050-0,080$ \\
4 & 0,076 & $0,075-0,010$ \\
5 & 0,089 & $0,075-0,010$ \\
\hline CE;48H médio (mg L & -1 \\
Faixa de sensibilidade & & 0,087 \\
Desvio Padrão & $0,076-0,110$ \\
Coeficiente de variação & \multicolumn{2}{c}{0,020} \\
\end{tabular}

Tabela 5.28 - Sensibilidade de D. similis ao Dicromato de Potássio.

\begin{tabular}{|ccc}
\hline \multicolumn{3}{c}{ Daphnia similis } \\
\hline Teste & CE(I)50 $\left(\mathbf{m g ~ L}^{-1}\right)$ & Intervalo de confiança $\left(\mathbf{m g ~ L}^{-1}\right)$ \\
\hline 1 & 0,080 & $0,070-0,090$ \\
2 & 0,120 & $0,100-0,150$ \\
3 & 0,150 & $0,120-0,190$ \\
4 & 0,120 & $0,100-0,160$ \\
5 & 0,083 & $0,063-0,011$ \\
\hline CE;48H médio (mg L & -1 \\
Faixa de sensibilidade & \multicolumn{2}{c}{0,111} \\
Desvio Padrão & $0,080-0,150$ \\
Coeficiente de variação & 0,029 \\
\end{tabular}

Nas concentrações empregadas neste estudo, verifica-se que os organismos testados com a substância referência dicromato de potássio, apresentam sensibilidade dentro das faixas de trabalho normalmente encontradas na literatura, ou seja, estão aptos para a utilização em testes de toxicidade.

\subsection{Teste de sensibilidade com cloreto de sódio ( $\mathrm{NaCl})$}

Nos testes de sensibilidade empregando-se cloreto de sódio, observa se que a variação entre as espécies foi pequena (Figuras 5.15 e 5.16). Os resultados da concentração efetiva a 50 \% da população (CE 50;48h) foram 2,4 $\mathrm{mg} \mathrm{L}^{-1}\left(1,856-2,919 \mathrm{mg} \mathrm{L}^{-1}\right)$ e $2,3 \mathrm{mg} \mathrm{L}^{-1}\left(1,638-2,901 \mathrm{mg} \mathrm{L}^{-1}\right)$, para $D$. laevis e $D$. similis respectivamente (Tabela 5.29 e 30). De acordo com estudos 
interlaboratoriais realizados em conjunto com a CETESB, verifica-se que os valores da CE $50 \%$ apresentados estão dentro da faixa que valida os testes.

$D$. laevis e $D$. similis apresentam um ciclo de vida muito similares. Isto implica na mesma resposta as substâncias testadas, uma vez que os organismos apresentam mesmo tamanho em 48 horas e apresentam também o mesmo número de ínstares neste período.

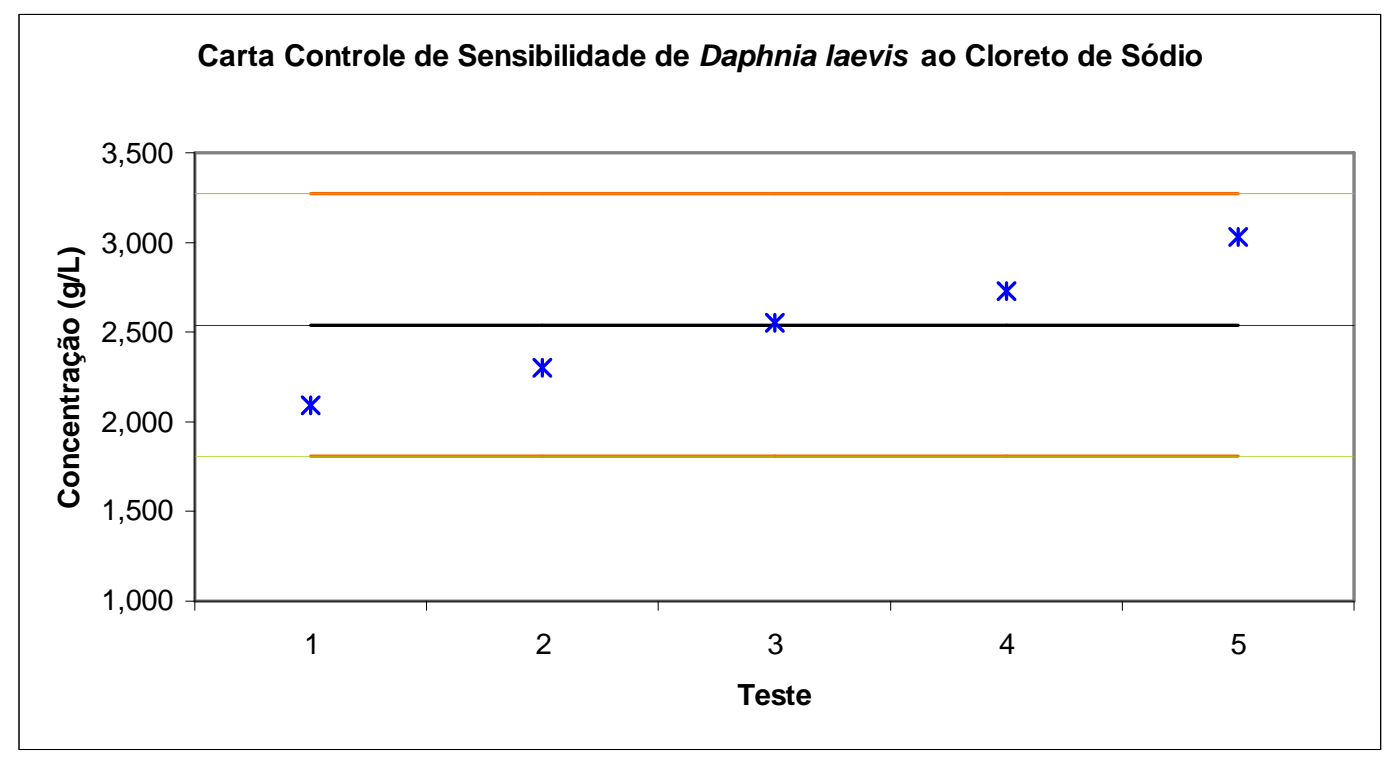

Figura 5.15 - Sensibilidade de Daphnia laevis ao cloreto de sódio.

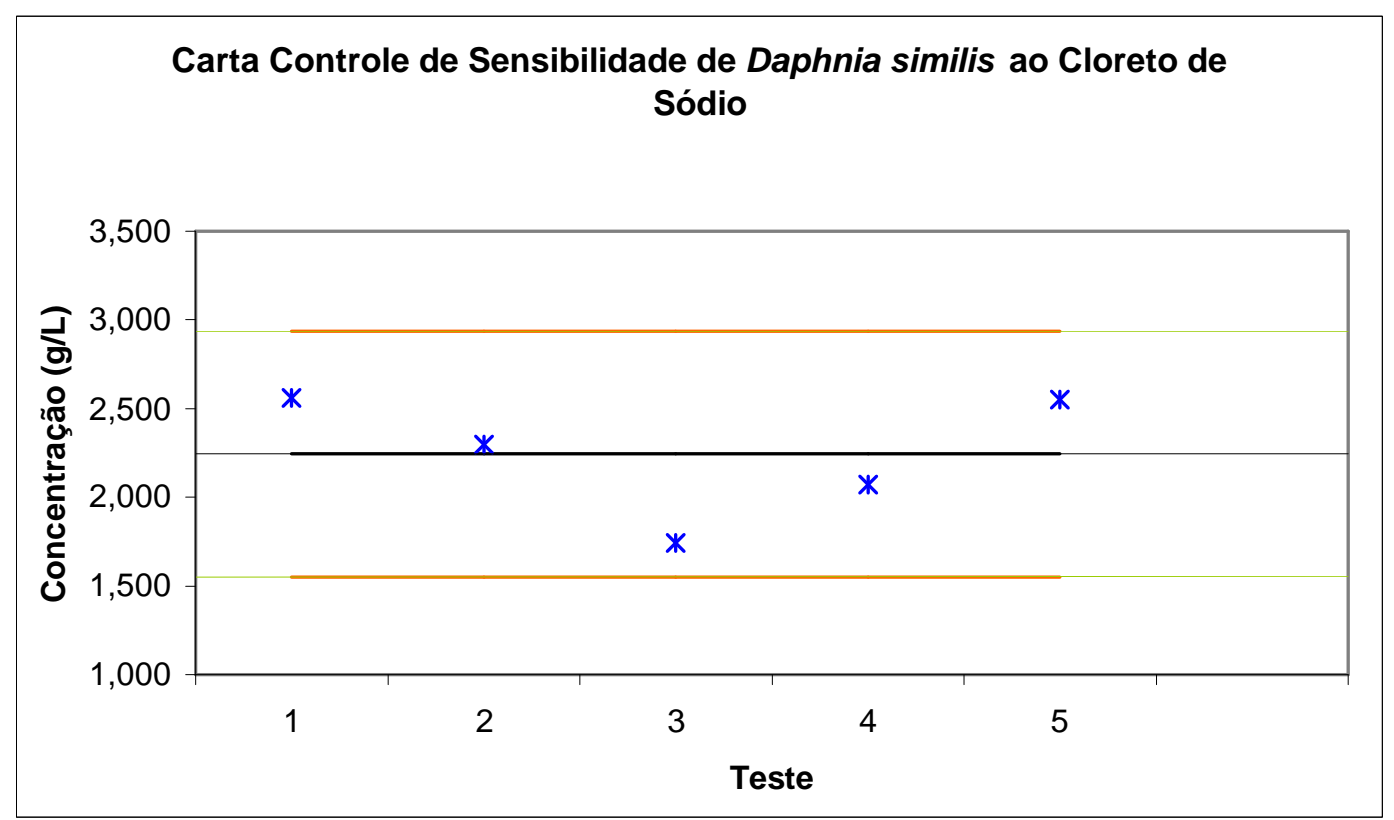

Figura 5.16 - Sensibilidade de Daphnia similis ao cloreto de sódio. 
Tabela 5.29 - Sensibilidade de D. laevis ao cloreto de sódio.

\begin{tabular}{|c|c|c|}
\hline \multicolumn{3}{|c|}{ D. laevis } \\
\hline Teste & CE(I)50 (mg L $\left.{ }^{-1}\right)$ & $\begin{array}{c}\text { Intervalo de confiança } \\
\left(\mathrm{mg} \mathrm{L}^{-1}\right)\end{array}$ \\
\hline 1 & 2,090 & $1,570-1,770$ \\
\hline 2 & 2. 300 & $1.960-2,690$ \\
\hline 3 & 2. 550 & $2,200-2,960$ \\
\hline 4 & 2,730 & $2,730-3,240$ \\
\hline 5 & 3,030 & $2,510-3,660$ \\
\hline CE;48H médio (mg L $\left.{ }^{-1}\right)$ & & 2,540 \\
\hline Faixa de sensibilidade & 2,7 & $0-3,000$ \\
\hline Desvio Padrão & & 366 \\
\hline Coeficiente de variação & & $14 \%$ \\
\hline
\end{tabular}

Tabela 5.30 - Sensibilidade de D. similis ao cloreto de sódio.

\begin{tabular}{|ccc}
\hline \multicolumn{3}{c}{ D. similis } \\
\hline Teste & $\begin{array}{c}\mathbf{C E}(\mathbf{I}) \mathbf{5 0} \\
\left(\mathbf{m g ~ L}^{-1}\right)\end{array}$ & $\begin{array}{c}\text { Intervalo de confiança } \\
\left(\mathbf{m g ~ L}^{-1}\right)\end{array}$ \\
\hline 1 & 2,297 & $1,967-2,682$ \\
2 & 1,741 & $1,428-2,123$ \\
3 & 2,071 & $1,775-2,416$ \\
4 & 2,549 & $2,282-2,847$ \\
5 & 2,400 & $2,000-2,900$ \\
\hline CE;48H médio & \multicolumn{2}{c}{2,212} \\
(mg L $^{-1}$ ) & \multicolumn{2}{c}{$1,741-2,549$} \\
Faixa de sensibilidade & 315 \\
Desvio Padrão & \multicolumn{2}{c}{$12 \%$} \\
Coeficiente de variação &
\end{tabular}

Segundo a USEPA (1986) a qualidade da água usada no cultivo de bioindicadores, a quantidade de alimento fornecido e as condiçoes em que foi preparado, oxigênio e temperatura, são fundamentais para a manutenção dos organismos para a realização de bioensaios. Modificações de qualquer um destes parâmetros podem afetar a variabilidade dos resultados. Além dos organismos testados pertencerem ao mesmo gênero, foram cultivados sob as mesmas condições, o que explicam a semelhança na sensibilidade as substâncias de referência. 
A concentração letal (CE 50\%) para o cloreto de sódio é maior que a obtida para dicromato de potássio, ou seja, este ultimo apresenta uma maior toxicidade que cloreto de sódio. Estes resultados estão relacionados à composição química e atuação das substâncias testadas, o $\mathrm{NaCl}$ atua na osmoregulação e o dicromato de potássio na excreção e respiração celular, processos mais importantes para a sobrevivência dos organismos.

\subsubsection{Testes de toxicidade dos fluidos empregando-se peixes - Danio rerio - Teleostei, Cyprinidae.}

Foram feitos 2 testes com peixes. Estes ensaios foram conduzidos em triplicata sendo 10 indivíduos por réplica em 4 concentrações dos fluidos e um branco. Os peixes foram mantidos em quarentena e nesse período foram observados a mortandade e movimentos natatórios. Optou-se por este número de testes, visto que os mesmos foram feitos após os ensaios com a bactéria Vibrio fischeri e com o daphnideos. Desta forma, teve-se um conhecimento prévio das concentrações letais dos demais organismos, evitando-se a morte de um grande número de peixes, os quais deveriam ser sacrificados após o teste mesmo que em caso de sobrevivência.

Foram feitos testes preliminares a fim de se determinar a faixa ideal de concentração dos fluidos de usinagem em solução. Iniciou-se com $25 \%$ da amostra do fluido e não $100 \%$ como recomenda a norma, pois com o alto índice de cor dessa matriz, dificultaria a observação do efeito dos fluidos sobre os organismos estudados. As concentrações dos fluidos foram: 6,0\%; 3,0\%; 1,5\% e 0,75 \%. As Tabelas 5. 31 a 5.36 apresentam os resultados dos testes de toxicidade dos fluidos de usinagem ao $D$. rerio. 
Tabela 5.31 - Testes de toxicidade do fluido mineral sem uso, amostra A empregando a espécie Danio rerio.

\begin{tabular}{c|c|c|c|c|c|c}
\hline Testes & \multicolumn{4}{|c|}{ Concentração/\% de } & CE \%, 48h & Efeito \\
\hline & 1 & 2 & 3 & 4 & & \\
\hline 1 & 95 & 65 & 40 & 20 & $\mathbf{0 , 9 0}(0,80$ a 1,10$)$ & T \\
\hline 2 & 90 & 60 & 25 & 10 & $\mathbf{1 , 1 0}(0,90$ a 1,30$)$ & T \\
\hline
\end{tabular}

T - Tóxico

Tabela 5.32 - Testes de toxicidade do fluido mineral usado, amostra A' empregando a espécie Danio rerio.

\begin{tabular}{c|c|c|c|c|c|c}
\hline Testes & \multicolumn{4}{|c|}{ Concentração/\% de } & CE \%, 48h & Efeito \\
\hline & 1 & 2 & 3 & 4 & & \\
\hline 1 & 90 & 70 & 35 & 15 & $\mathbf{0 , 9 4}(0,84$ a 1,14) & T \\
\hline 2 & 95 & 65 & 25 & 10 & $\mathbf{0 , 9 8}(0,88$ a 1,08$)$ & T \\
\hline
\end{tabular}

A Figura 5.17 apresenta os resultados dos testes de toxicidade das amostras de fluido mineral sem uso e usado para a espécie $D$. rerio.

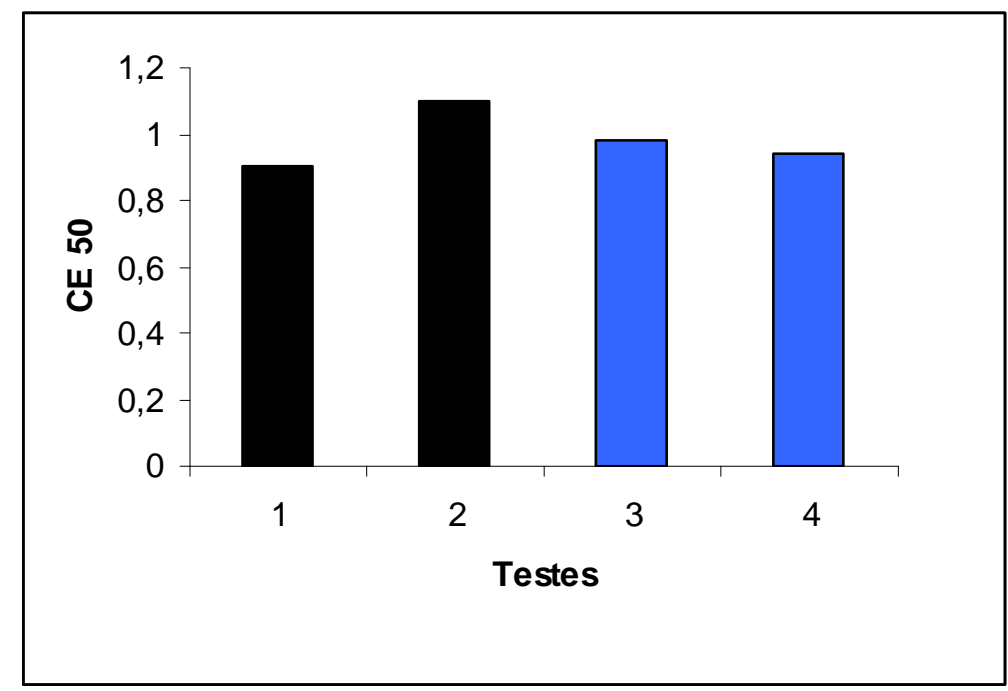

Figura 5.17 - Resultados dos testes de toxicidade do fluido mineral sem uso (preto) e usada (azul) para Danio rerio.

Verifica-se pelas Tabelas 5.31 e 5.32 e a Figura 5.17, que os valores das concentrações efetivas estão próximos, o que evidencia o uso do fluido mineral na usinagem de peças metálicas não diminui sua toxicidade, ou seja, mesmo 
após meses de contato com ar e água nos processos industriais, o fluido mineral não perde seu índice de toxidez. O fluido mineral é muito nocivo para o D. rerio, visto que uma concentração inferior a $1 \%$ pode causar a morte de metade da comunidade.

Tabela 5.33 - Testes de toxicidade do fluido semi-sintético sem uso, amostra B, empregando a espécie Danio rerio.

\begin{tabular}{c|c|c|c|c|c|c}
\hline Testes & \multicolumn{4}{|c|}{$\begin{array}{c}\text { Concentração/\% de } \\
\text { Efeito }\end{array}$} & CE \%, 48h & Efeito \\
\hline & 1 & 2 & 3 & 4 & & \\
\hline 1 & 95 & 70 & 35 & 20 & $\mathbf{1 , 8}(1,60$ a 2,00) & T \\
\hline 2 & 90 & 65 & 25 & 10 & $\mathbf{1 , 6}(1,40$ a 1,80) & T \\
\hline
\end{tabular}

T - Tóxico

Tabela 5.34 - Testes de toxicidade do fluido semi-sintético usado, amostra B', empregando a espécie Danio rerio.

\begin{tabular}{c|c|c|c|c|c|c}
\hline Testes & \multicolumn{4}{|c|}{ Concentração/\% de } & CE \%, 48h & Efeito \\
\hline & 1 & 2 & 3 & 4 & & \\
\hline 1 & 95 & 70 & 30 & 15 & $\mathbf{1 , 4}(1,20$ a 1,60) & T \\
\hline 2 & 85 & 65 & 25 & 10 & $\mathbf{1 , 3}(1,10$ a 1,50$)$ & T \\
\hline
\end{tabular}

T - Tóxico

A Figura 5.18 apresenta os resultados dos testes de toxicidade das amostras de fluido semi-sintético sem uso e usado ao $D$. rerio.

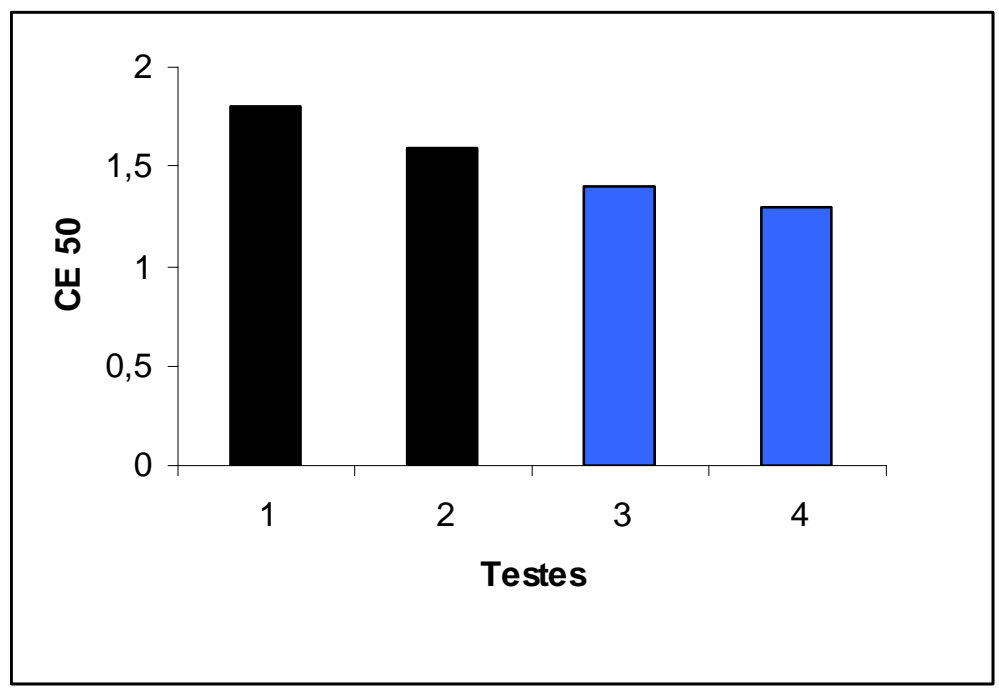

Figura 5.18 - Resultados dos testes de toxicidade dos fluidos B (preto) e B'(azul) para Danio rerio. 
Observa-se nestes testes, um aumento da toxicidade das amostras de fluido de usinagem. Este fato esta provavelmente relacionado com o tipo de maquinário a que a mostra usada foi exposta e aos subprodutos que se originam neste processo.

Tabela 5.35 - Testes de toxicidade do fluido sintético sem uso, amostra C, empregando a espécie Danio rerio.

\begin{tabular}{c|c|c|c|c|c|c}
\hline Testes & \multicolumn{4}{|c|}{$\begin{array}{c}\text { Concentração/\% de } \\
\text { Efeito }\end{array}$} & CE \%, 48h & Efeito \\
\hline & 1 & 2 & 3 & 4 & & T \\
\hline 1 & 90 & 70 & 35 & 15 & $\mathbf{2 , 3}(2,10$ a 2,50) & T \\
\hline 2 & 90 & 65 & 25 & 15 & $\mathbf{2 , 6}(2,40$ a 2,80) & \\
\hline
\end{tabular}

T - Tóxico

Tabela 5.36 - Testes de toxicidade do fluido sintético usada, amostra C', empregando a espécie Danio rerio.

\begin{tabular}{c|c|c|c|c|c|c}
\hline Testes & \multicolumn{4}{|c|}{$\begin{array}{c}\text { Concentração/\% de } \\
\text { Efeito }\end{array}$} & CE \%, 48h & Efeito \\
\hline & 1 & 2 & 3 & 4 & & \\
\hline 1 & 95 & 70 & 30 & 15 & $\mathbf{2 , 6}(2,40$ a 2,80) & T \\
\hline 2 & 90 & 65 & 30 & 20 & $\mathbf{2 , 7}(2,50$ a 2,90) & T \\
\hline
\end{tabular}

T - Tóxico

A Figura 5.19 apresenta os valores das concentrações efetivas a $50 \%$ dos indivíduos para as amostras de fluido sintético (C e C')

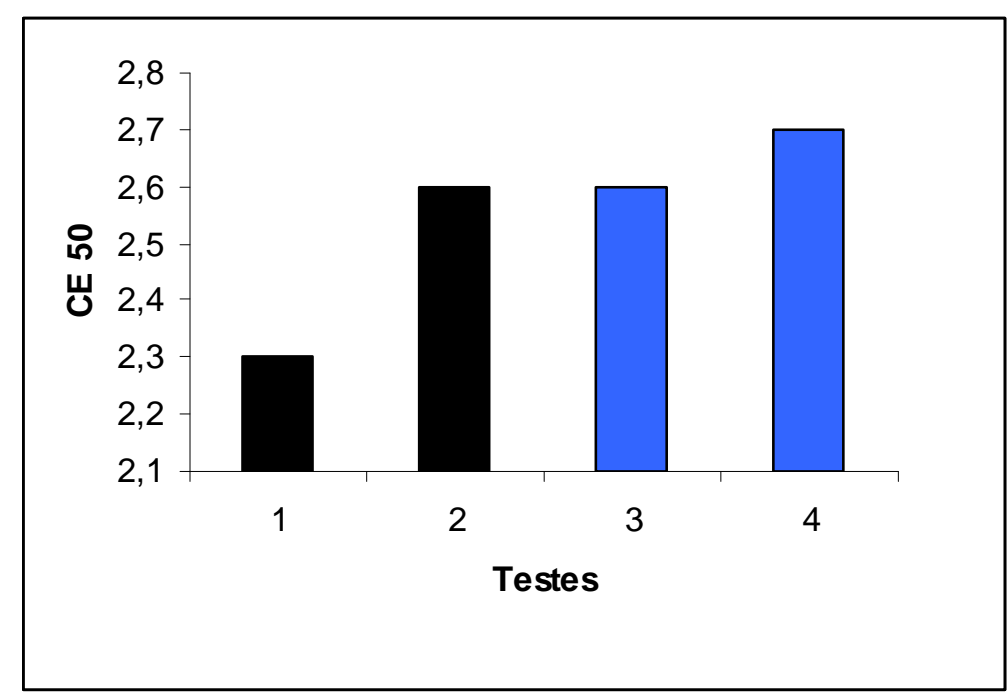

Figura 5.19 - Resultados dos testes de toxicidade das amostras de fluido C (preto) e C'(azul) para Danio rerio. 
Verifica-se pelos resultados apresentados nas Tabelas 5.35 e 5.36 e na Figura 5.19, que a toxicidade dos fluidos estão muito próximas, demonstrando que o produto tem alta estabilidade e alta toxicidade. De todos os fluidos estudados, o fluido sintético foi o que apresentou menor toxicidade frente a este organismo, Danio rerio, com concentração efetiva média de 2,5\% da amostra de fluido sintético sem diluições. Durante os testes as reações mais freqüentes observadas nos peixes foram à perda do equilíbrio e a falta de movimentação, seguidas de morte.

O dicromato de potássio foi a substância referência que foi aplicada também para a avaliação dos testes com $D$. rerio nos testes de sensibilidade. Foram empregadas concentrações: entre $50,0 \mathrm{mg} \mathrm{L}^{-1}$ e $333,33 \mathrm{mg} \mathrm{L}^{-1}$, preparadas a partir de um padrão com $1000 \mathrm{mg} \mathrm{L}^{-1}$ de $\mathrm{K}_{2} \mathrm{Cr}_{2} \mathrm{O}_{7}$.

Os valores de sensibilidade do Danio rerio ao dicromato de potássio foram obtidos de acordo com USEPA (1994). A media dos valores obtidos para CE 50\% em $24 \mathrm{~h}$ foi de 52,36 $\mathrm{mg} \mathrm{L}^{-1}$ de dicromato de potássio. Esses resultados estão de acordo com a literartura, mostrando que os peixes encontravam-se saudáveis. Para considerar os testes de toxicidade com $D$. rerio válidos: a mortalidade no controle não pode exceder a $20 \%$ e a temperatura da água na faixa de $25^{\circ} \mathrm{C} \pm 1^{\circ} \mathrm{C}$. Além dos testes de toxicidade, foram feitos testes de viabilidade para a avaliação da qualidade da água de cultivo (USEPA, 2002), 


\subsubsection{Viabilidade da Água de Cultivo.}

A Tabela 5.37 apresenta os resultados dos testes de viabilidade da água de cultivo dos organismos feitos com as amostras de água coletadas na Represa Paiva Castro (Mairiporã, SP).

Tabela 5.37 - Testes de viabilidade da água para cultivo de organismos aquáticos.

\begin{tabular}{c|c|c|c|c|c}
\hline Local & Data & $\mathbf{p H}$ & $\begin{array}{c}\text { Dureza } \\
\left(\mathbf{m g ~ L}^{-1} \mathbf{C a C o}_{3}\right)\end{array}$ & $\begin{array}{c}\text { Condutividade } \\
\left(\mu \mathbf{S ~ c m}^{-2}\right)\end{array}$ & $\begin{array}{c}\% \text { de } \\
\text { Imóveis }\end{array}$ \\
\hline Mairiporã & $10 / 02 / 05$ & 7,01 & 45 & 122,0 & 6 \\
\hline Mairiporã & $16 / 03 / 05$ & 7,00 & 46 & 109,6 & 2 \\
\hline Mairiporã & $14 / 04 / 05$ & 7,02 & 44 & 104,2 & 4 \\
\hline Mairiporã & $10 / 05 / 05$ & 7,00 & 45 & 118,0 & 2 \\
\hline Mairiporã & $14 / 06 / 05$ & 7,01 & 44 & 110,2 & 2 \\
\hline
\end{tabular}

De acordo com a Norma CETESB L5.018 (1994), a água de Mairiporã mostrou-se apropriada para os cultivos, pois o percentual de imobilidade não excedeu a $10 \%$. Verifica-se que a represa de Mairiporã foi a única utilizada no período dos testes, pois as outras fontes apresentaram mortandade dos organismos e por isso foram temporariamente excluídas das coletas. 


\subsubsection{Testes de toxicidade das amostras de fluidos após a irradiação}

As amostras dos fluidos foram irradiadas no laboratório de tecnologia das radiações IPEN nas dose 10 e 100 kGy. Após este processo, as amostras foram acondicionadas em frascos de vidro âmbar e preservadas da luz e calor. Fez-se então, testes com todas as amostras, porem utilizou-se somente a bactéria luminescente, $V$. fisheri devido a sua eficiência e rapidez nas respostas e sendo um organismo padronizado internacionalmente, fornecendo assim resultados confiáveis.

Foram feitos três testes com cada amostra irradiada. Inicialmente aplicou-se uma dose de $10 \mathrm{kGy}$ para avaliação da toxicidade. As Tabelas 5.38 a 5.43 apresentam os resultados dos testes para as amostras de fluido de usinagem.

Tabela 5.38 - Toxicidade aguda da amostra de fluido mineral sem uso irradiada com 10 kGy frente a bactéria $V$. fischeri .

\begin{tabular}{c|c|c|c|c}
\hline Teste & CE 50 (\%) & \multicolumn{2}{|c|}{ Intervalo de Confiança } & Fator de Confiança \\
\hline 1 & 0,0080 & 0,006 & 0,010 & 1,1530 \\
\hline 2 & 0,0060 & 0,004 & 0,008 & 1,0890 \\
\hline 3 & 0,0080 & 0,006 & 0,010 & 1,1017 \\
\hline
\end{tabular}

Tabela 5.39 - Toxicidade aguda de fluido mineral usado irradiada com 10 kGy frente a bactéria $V$. fischeri .

\begin{tabular}{c|c|c|c|c}
\hline Teste & CE 50 (\%) & \multicolumn{2}{|l|}{ Intervalo de Confiança } & Fator de Confiança \\
\hline 1 & 0,0022 & 0,0020 & 0,0024 & 1,0580 \\
\hline 2 & 0,0018 & 0,0016 & 0,0020 & 1,1124 \\
\hline 3 & 0,0023 & 0,0021 & 0,0025 & 1,1247 \\
\hline
\end{tabular}

Verifica-se pelos resultados das Tabelas 5.38 e 5.39 que o fluido mineral usado, apresentou maior CE50 que a do fluido sem uso, após a irradiação com uma dose de $10 \mathrm{kGy}$, indicando que o fluido usado teve degradação de algum 
componente ou formação de uma nova substância durante o seu uso na usinagem de peças metálicas.

Tabela 5.40 - Toxicidade aguda das amostras de fluido semi-sintético sem uso irradiada com $10 \mathrm{kGy}$ frente a bactéria $V$. fischeri .

\begin{tabular}{c|c|c|c|c}
\hline Teste & CE $\mathbf{5 0}(\%)$ & \multicolumn{2}{|c}{ Intervalo de Confiança } & Fator de Confiança \\
\hline 1 & 0,0088 & 0,0084 & 0,0092 & 1,0452 \\
\hline 2 & 0,0094 & 0,0090 & 0,0098 & 1,1132 \\
\hline 3 & 0,0082 & 0,0078 & 0,0086 & 1,0862 \\
\hline
\end{tabular}

Tabela 5.41 - Toxicidade aguda de fluido semi-sintético usado irradiada com 10 kGy frente a bactéria $V$. fischeri .

\begin{tabular}{c|c|c|c|c}
\hline Teste & CE 50 (\%) & \multicolumn{2}{|l|}{ Intervalo de Confiança } & Fator de Confiança \\
\hline 1 & 0,0124 & 0,0120 & 0,0128 & 1,0021 \\
\hline 2 & 0,0142 & 0,0138 & 0,0146 & 1,1472 \\
\hline 3 & 0,0138 & 0,0134 & 0,0142 & 1,0758 \\
\hline
\end{tabular}

Observou-se pelos resultados das Tabelas 5.40 e 5.41 que ocorreu uma diferença significativa entre os fluidos sem uso e usado, sendo o fluido usado menos tóxico a espécie $V$. fischeri após a sua irradiação, contudo, a toxicidade do fluido usado irradiado foi maior que sem irradiação. 
Tabela 5.42 - Toxicidade aguda de fluido sintético sem uso irradiada com 10 kGy frente a bactéria $V$. fischeri .

\begin{tabular}{c|c|c|c|c}
\hline Teste & CE 50 (\%) & \multicolumn{2}{|c|}{ Intervalo de Confiança } & Fator de Confiança \\
\hline 1 & 0,0104 & 0,0100 & 0,0108 & 1,1490 \\
\hline 2 & 0,0110 & 0,0106 & 0,0114 & 1,0810 \\
\hline 3 & 0,0113 & 0,0110 & 0,0116 & 1,2328 \\
\hline
\end{tabular}

Tabela 5.43. Toxicidade aguda de fluido sintético usado irradiada com 10 kGy frente a bactéria $V$. fischeri .

\begin{tabular}{c|c|c|c|c}
\hline Teste & CE 50 (\%) & \multicolumn{2}{|c|}{ Intervalo de Confiança } & Fator de Confiança \\
\hline 1 & 0,0138 & 0,0134 & 0,0142 & 1,1124 \\
\hline 2 & 0,0146 & 0,0142 & 0,0152 & 1,1830 \\
\hline 3 & 0,0133 & 0,0130 & 0,0136 & 1,0008 \\
\hline
\end{tabular}

Verifica-se pelos resultados das Tabelas 5.42 e 5.43 que a toxicidade para a bactéria luminescente foi semelhante para ambas as amostras de fluido sintético sem uso e usado após irradiação. Os valores das concentrações efetivas para $50 \%$ - CE50, dos indivíduos do teste estão bem próximos caracterizando grande estabilidade do fluido após a irradiação.

Após serem feitos os ensaios com as amostras de fluidos irradiadas com 10 kGy, optou-se por aumentar para uma dose de 100 kGy para se verificar se esta era mais eficiente na degradação das substâncias presentes nos fluidos em estudo.

As Tabelas 5.44 a 4.49 apresentam os valores obtidos nos testes de toxicidade feitas no sistema Microto ${ }^{\circledR}$ para os fluidos de usinagem de peças metálicas para uma dose de 100 kGy. 
Tabela 5.44 - Toxicidade aguda do fluido mineral sem uso irradiada com 100 kGy frente a bactéria $V$. fischeri .

\begin{tabular}{c|c|c|c|c}
\hline Teste & CE 50 (\%) & \multicolumn{2}{|c|}{ Intervalo de Confiança } & Fator de Confiança \\
\hline 1 & 0,0070 & 0,0050 & 0,0090 & 1,1021 \\
\hline 2 & 0,0090 & 0,0070 & 0,0110 & 1,1175 \\
\hline 3 & 0,0080 & 0,0060 & 0,0100 & 1,0978 \\
\hline
\end{tabular}

Tabela 5.45 - Toxicidade aguda do fluido mineral usado irradiada com 100 kGy frente a bactéria $V$. fischeri .

\begin{tabular}{c|c|c|c|c}
\hline Teste & CE 50 (\%) & \multicolumn{2}{|c|}{ Intervalo de Confiança } & Fator de Confiança \\
\hline 1 & 0,0034 & 0,0030 & 0,0038 & 1,0114 \\
\hline 2 & 0,0029 & 0,0025 & 0,0033 & 1,1217 \\
\hline 3 & 0,0040 & 0,0036 & 0,0044 & 1,1005 \\
\hline
\end{tabular}

Verifica-se nas Tabelas 5.44 e 5.45 que o fluido mineral usado, apresentou maior CE50 que a do fluido sem uso, após a irradiação com uma dose de 100 kGy, indicando que pode ter havido degradação de algum componente tóxico presente no fluido usado.

Tabela 5.46 - Toxicidade aguda do fluido semi-sintético sem uso irradiada com 100 kGy frente a bactéria $V$. fischeri .

\begin{tabular}{c|c|c|c|c}
\hline Teste & CE 50 (\%) & \multicolumn{2}{|c|}{ Intervalo de Confiança } & Fator de Confiança \\
\hline 1 & 0,0051 & 0,0048 & 0,0054 & 1,1210 \\
\hline 2 & 0,0042 & 0,0038 & 0,0046 & 1,0487 \\
\hline 3 & 0,0044 & 0,0040 & 0,0048 & 1,1124 \\
\hline
\end{tabular}

Tabela 5.47 - Toxicidade aguda do fluido semi-sintético usado irradiada com 100 kGy frente a bactéria $V$. fischeri .

\begin{tabular}{c|c|c|c|c}
\hline Teste & CE 50 (\%) & \multicolumn{2}{|c|}{ Intervalo de Confiança } & Fator de Confiança \\
\hline 1 & 0,0088 & 0,0084 & 0,0092 & 1,1498 \\
\hline 2 & 0,0093 & 0,0090 & 0,0096 & 1,1741 \\
\hline 3 & 0,0080 & 0,0076 & 0,0080 & 1,0937 \\
\hline
\end{tabular}


Observa-se nas Tabelas 5.46 e 5.47 que ocorrem uma diferença nos valores da CE50 entre os fluidos sem uso e usado, sendo o fluido usado menos tóxico a espécie $V$. fischeri após a sua irradiação.

Tabela 5.48 - Toxicidade aguda do fluido sintético sem uso irradiada com 100 kGy frente a bactéria $V$. fischeri .

\begin{tabular}{c|c|c|c|c}
\hline Teste & CE 50 (\%) & \multicolumn{2}{|l|}{ Intervalo de Confiança } & Fator de Confiança \\
\hline 1 & 0,0099 & 0,0095 & 0,0103 & 1,1213 \\
\hline 2 & 0,0095 & 0,0092 & 0,0098 & 1,1084 \\
\hline 3 & 0,0091 & 0,0088 & 0,0094 & 1,0650 \\
\hline
\end{tabular}

Tabela 5.49 - Toxicidade aguda do fluido sintético usado irradiada com 100 kGy frente a bactéria $V$. fischeri .

\begin{tabular}{c|c|c|c|c}
\hline Teste & CE 50 (\%) & \multicolumn{2}{|c|}{ Intervalo de Confiança } & Fator de Confiança \\
\hline 1 & 0,0087 & 0,0083 & 0,0091 & 1,0520 \\
\hline 2 & 0,0079 & 0,0075 & 0,0083 & 1,1173 \\
\hline 3 & 0,0092 & 0,0088 & 0,0096 & 1,0994 \\
\hline
\end{tabular}

Verifica-se nas Tabelas 5.48 e 5.49 que os dados da toxicidade para a bactéria luminescente foi semelhante para o fluido sintético sem uso e usado após irradiação. Os valores das concentrações efetivas para $50 \%$ dos indivíduos do teste estão bem próximos caracterizando grande estabilidade deste produto frente à radiação gama.

Observa-se pelos dados apresentados pelas Tabelas 5.38 a 5.49 , que a toxicidade aumentou após a irradiação em todas as amostras de fluido de usinagem. Portanto, o uso da radiação parece ser inadequado para 0 tratamento de amostras de fluido, visto que os subprodutos da degradação radiolítica são ainda mais tóxicos aos organismos aquáticos presentes nos corpos d'água. 
De acordo com DUARTE (1999), a radiação pode reduzir a presença de compostos orgânicos degradáveis em mais de 90 \%, no entanto, reduções semelhantes não foram observadas para outras análises físicas e químicas tais como; surfactantes, compostos fenólicos, etc.

Os quatro organismos testados, Vibrio fischeri, Daphnia similis, Daphnia laevis e Danio rerio responderam de maneira semelhante em relação ás diferentes amostras, fluido mineral, semi-sintético e sintético. Das 6 amostras utilizadas nos ensaios, a que mais surpreendeu por apresentar toxicidade elevada, foi à sintética de base polimérica ( $\mathrm{C}$ e $\left.\mathrm{C}^{\prime}\right)$, a qual é formulada com substâncias que em teoria não seriam tóxicas a organismos aquáticos. O fluido é apresentado pelos fabricantes como ambientalmente correto, pois não são bioacumulados nos sedimentos, degradando-se rapidamente na coluna d' água.

ARENZON (2004) quando analisou a aplicabilidade de ensaios de toxicidade na avaliação da qualidade de águas subterrâneas potencialmente impactadas, observou uma alta variabilidade na toxicidade para os mesmos organismos-teste para uma mesma amostra. Desta forma, as diferenças significativas entre os resultados apresentados para os diferentes organismos, é algo plausível. Ainda segundo ARENZON (2004) a variabilidade dos efeitos tóxicos pode estar relacionada com as diferenças na sensibilidade dos organismos, a complexidade dos compostos presentes nas amostras, a biodisponibilidade de certas substâncias ou pode ser decorrente da presença de substâncias que não puderam ser analisadas.

GEIS et al. (2000) mostram em seus estudos que geralmente as algas apresentam-se mais sensíveis as substâncias testadas que invertebrados e peixes em $50 \%$ dos casos, mas podem ser menos sensíveis em $30 \%$ dos casos. RODRIGUES (2002) concluiu que os microcrustáceos podem ser considerados um bom organismo-teste indicador de impactos ambientais, podendo ser inclusive mais sensíveis que outros organismos da biota aquática, quando expostos a um mesmo agente. 


\subsection{Testes de Biodegradabilidade}

\subsubsection{Testes de biodegradação em ambientes aquáticos.}

Os testes de biodegradabilidade dos fluidos de usinagem em água foram feitos no laboratório de Tecnologia Ambiental (TECAM - SP). Contudo, ao seguir as normas sugeridas para o teste, verificou-se que os resultados eram inconclusivos, ou seja, após aproximadamente quatorze dias de duração (de um total de 28) a depleção de oxigênio era total. Tal fato sugere que mesmo em uma concentração bastante reduzida, a amostra ainda é altamente tóxica as bactérias utilizadas no teste e que seriam responsáveis pela degradação da amostra.

Não foi possível fazer modificações na metodologia, visto existir um limite químico para a diluição da amostra. Novas diluições implicariam no aumento dos erros analíticos, tornando o teste invalido.

\subsubsection{Biorremediação de solo}

Os fluidos proporcionaram crescimento de microrganismos nas amostras de solo da região de São Carlos, sendo necessário, para alguns destes a adição de fonte alternativa de carbono. As bactérias foram repicadas (separadas e inseridas em um novo meio de cultura) e purificadas, partindo-se para o estudo de identificação das mesmas. Os organismos presentes no solo e na presença do fluido A' não apresentaram crescimento em 24 h quando repicados para o meio apropriado, condição exigida para a análise dos ácidos graxos (AMARANTE JR et al, 2005).

$\mathrm{Na}$ análise cromatográfica, foi feita a análise do branco, não foi observado nenhum sinal referente a ésteres de ácidos graxos. A análise 
cromatográfica de uma substância padrão apresentou índice de similaridade igual a 0,999. Isto foi considerado como sendo um bom índice, pois garantiu a confiabilidade dos dados obtidos. As análises resultaram na identificação dos microrganismos, com os índices de similaridade, apresentados na Tabela 5.50.

TABELA 5.50 - Denominação das bactérias encontradas nas amostras de fluido de usinagem, sua similaridade e espécie.

\begin{tabular}{|c|c|c|}
\hline $\begin{array}{l}\text { Isolado } \\
\text { (códigos) }\end{array}$ & Índice de similaridade & $\begin{array}{c}\text { Bactérias encontradas nas amostras } \\
\text { de solo contaminadas com fluido de } \\
\text { usinagem }\end{array}$ \\
\hline A' M4 & 0.707 & Bacillus pumilus GC subgrupo $B$ \\
\hline A M4 & 0.381 & Bacillus cereus GC subgrupo A \\
\hline A M4 & 0.597 & $\begin{array}{c}\text { Arthrobacter nicotianae } G C \\
\text { subgrupo } B\end{array}$ \\
\hline $\mathrm{A}^{\prime} \mathrm{M} 4$ & 0.595 & Paenibacillus chondroitinus \\
\hline A O5 & 0.424 & Bacillus cereus GC subgrupo B \\
\hline A O5 & 0.569 & Kurthia gibsonii \\
\hline$A^{\prime} 05$ & 0.846 & Sphingobacterium thalpophilum \\
\hline B' O5 & 0.697 & Salmonella typhi GC subgrupo A \\
\hline В 05 & 0.734 & Cedecea davisae \\
\hline B' O5 & 0.796 & Cedecea davisae \\
\hline C M4 & 0.588 & Paenibacillus lentimorbus \\
\hline C'M4 & 0.503 & Paenibacillus lentimorbus \\
\hline C M4 & 0.593 & Bacillus mycoides GC subgrupo A \\
\hline C'M4 & 0.771 & Pseudomonas putida BA \\
\hline C' 04 & 0.683 & Salmonella typhi GC subgrupo A \\
\hline C'O4 & 0.734 & Bacillus pumilus GC subgrupo B \\
\hline C'04 & 0.735 & Salmonella typhi GC subgrupo A \\
\hline
\end{tabular}

Resultados em negrito referem-se a índices de similaridade superior a $70 \%$.

Os organismos identificados com a letra $\mathbf{A}$ representam os fluidos minerais, a letra B os semi-sintéticos e $C$ os sintéticos. Aqueles seguidos da 
letra $M$ foram inoculados empregando uma fonte alternativa de carbono, enquanto que os demais não foi adicionada fonte de carbono.

Para o fluido $A$, com a presença de fonte alternativa de carbono observou-se a presença da bactéria identificada como Bacillus pumilus, enquanto que, sem a adição de suplemento, observou-se o crescimento da bactéria identificada como Sphingobacterium thalpophilum. Esta última consiste em uma bactéria aeróbica, gram-negativa, oxidante da glucose em meio fermentativo-oxidativo, encontrado no ambiente e em humanos acometidos de infecções oportunistas (NAKA et al.s2003). As demais bactérias identificadas não apresentaram índice de similaridade suficiente para uma análise conclusiva.

Para o fluido do tipo $B$, sem a adição de fonte alternativa de carbono, observou-se o crescimento de dois tipos de microrganismos, identificados como Cedecea davisae e Salmonella typhi. Estes organismos ainda não são muito estudados e por isso, cepas dos mesmos foram preservadas pela EMBRAPA para estudos futuros.

$\mathrm{Na}$ amostra C' M4 encontrou-se o organismo identificado como Pseudomonas putida. Bactérias deste gênero já foram reportadas como as mais abundantes no estudo da degradação de fluidos de corte (VAN DER GAST et al., 2001). Estes organismos têm uma ampla aplicabilidade em processos de degradação, pois são encontrados tanto em solo quanto em água. Esta bactéria também foi identificada como envolvida no processo de degradação de herbicidas como o 2,4-D (HOBBEN et al., 1988). Por ser uma bactéria heterotrófica, ela pode empregar a mesma molécula como fonte de carbono, nitrogênio e energia. Esta bactéria foi investigada em estudos de biodegradação de p-nitrofenol (IGNATOV et al., 2002). 
Para o mesmo fluido de corte, mas sem a adição de fonte alternativa de carbono, pôde-se observar o crescimento de dois tipos de microrganismos, identificados como: Salmonella typhi e Bacillus pumilus. CALVO et al. (2004) reportaram o importante papel de bactérias Bacillus pumilus como biosurfactante, a qual cresce em meio aquoso e em solo, removendo compostos como naftaleno. Esta ação é explicada pelo fato de algumas bactérias ligarem-se à molécula do poluente, transformando-se em uma emulsão, por isto chamadas de biosurfactantes. Isto pode facilitar a degradação do hidrocarboneto pelo contato direto da célula com o composto além de aumentar a mobilidade deste composto na fase aquosa, favorecendo o contato com outros organismos capazes de degradá-lo. Este tipo de organismo é considerado como sendo uma importante ferramenta em processos de biodegradação.

De acordo com os resultados anteriormente descritos, pode-se afirmar que o método analítico empregado, se apresentou bastante eficiente na identificação dos microrganismos presentes em amostras de solo contaminadas com fluidos de usinagem de peças metálicas, sendo de fácil execução. Dos microrganismos encontrados nas amostras de solo contaminadas com os fluidos mineral, semi-sintético e sintético, alguns já apresentam estudos sobre degradação de compostos provenientes do petróleo ou de outras fontes de degradação. Ressalta-se o papel importante do Bacillus pumilus que pode ser empregado em consórcio com outros microrganismos facilitando a emulsificação de diversos tipos de poluentes orgânicos de origem doméstica ou industrial. Outros microrganismos não apresentaram grau de similaridade adequado para que se considerassem os estudos conclusivos, sendo necessário, portanto, novas investigações, podendo-se encontrar, inclusive, novas espécies de microrganismos.

Nos processos de decomposição de substâncias poluentes, muitas vezes podem ocorrer resultados inesperados como, a existência de resíduos 
não degradados após a biorremediação. Este fato normalmente esta associado a diversos fatores, dentre os quais destacam-se, grupo microbiológico inadequado; barreiras fisiológicas (deficiência de nutrientes, por exemplo); biodisponibilidade insuficiente do composto desejado; formação de substâncias secundárias, ou seja, metabólitos tóxicos; presença de compostos persistentes (WANG et al., 1995). Para estes últimos, dá-se o nome de marcadores ou biomarcadores. Normalmente, estas substâncias são empregadas para se relacionar a presença de um determinado composto (no ambiente ou em tecidos animais ou vegetais). Com a origem da contaminação, uma vez que alguns deles são de origem bem definida, ou seja, de fácil comprovação (WANG et al., 1994). Para o tratamento de aqüíferos, a tecnologia mais empregada consiste na injeção de ar, favorecendo a degradação dos compostos por ação dos microrganismos locais. Estudos de degradação de benzeno, tolueno e xileno comprovaram a total degradação destes três compostos após 126 dias (SPILBORGHS, 1997).

Os fluidos de corte estudados apresentaram elevada toxicidade e baixa taxa de biodegradação. Estes dados são preocupantes visto que pouco se sabe sobre as propriedades destes materiais e seus efeitos nos sistemas naturais. De acordo com os resultados encontrados neste estudo, pode-se afirmar que a associação de tecnologias para o diagnóstico e monitoramento de resíduos pode ser a única alternativa viável na redução da toxicidade de amostras complexas como as de fluidos de usinagem de peças metálicas. 


\section{CONSIDERAÇÕES FINAIS}

De modo geral, o meio ambiente, em especial os recursos hídricos tem recebido descargas de poluentes sem nenhum controle. As indústrias são infelizmente, as principais causadoras desta poluição, na forma de descartes regulares, irregulares ou como derramamentos acidentais. Dentre estas empresas, a indústria metal - mecânica ocupa destaque visto que despeja uma grande quantidade de substâncias tóxicas ao longo de todos os compartimentos ambientais, no ar em forma de fumaça e partículas diminutas, por exemplo, e nos solos e na água como materiais sólidos ou líquidos. Estas substâncias tóxicas são principalmente os fluidos de usinagem de peças metálicas, os quais são usados como líquidos refrigerantes ou lubrificantes.

Estes fluidos podem ser constituídos de substâncias de origem mineral, semi-sintéticos (vegeto-animais), compostos por ésteres de ácidos graxos, álcoois, entre outras; ou fluidos sintéticos, de composição menos complexa, embora mais difícil de ser determinada. De qualquer forma, estes produtos para atender as necessidades do mercado são acrescidos de várias substâncias que aumentam a sua estabilidade, sua durabilidade, melhora as suas propriedades lubrificantes, refrigerantes e seu tempo de vida útil entre outras mudanças, diminuindo assim os custos com a produção. Esses compostos adicionados são normalmente biocidas, tensoativos entre outros tipos de substâncias, as quais melhoram as condições de comercialização, mas que ao mesmo tempo pode inferir um aumento de toxicidade. 
Considerando a complexidade de tais compostos, coube avaliar a toxicidade de 6 diferentes fluidos de usinagem de peças metálicas comercializados no mercado brasileiro, sendo todos solúveis em água. Estes fluidos são emulsionáveis, de origem mineral, sintética ou semi-sintética, sendo constituídos de ésteres, aminas, amidas, glicol, álcoois e silicones.

Em virtude desta alta complexidade, foi estudada a toxicidade aguda destes fluidos para organismos de diferentes níveis tróficos, observando-se que os fluidos apresentam grande mobilidade nos ambientes aquáticos quando em um despejo em um corpo d' água ou, podendo atingir rapidamente os lençóis subterrâneos quando despejados no solo.

Em decorrência destas diferenças de composição, os fluidos apresentam comportamento diferenciado para cada espécie de organismo sendo mais tóxicas para uma e ao mesmo tempo tendo sua toxicidade reduzida para outras. Alguns destes fluidos foram degradados ou pode ter ocorrido formação de constituintes degradados durante o uso, principalmente por serem utilizados dissolvidos em água. Outros mais persistentes, não foram degradados durante a operação a que se propõe.

De forma geral, os fungos e bactérias presentes no solo, são em geral, capazes de degradar os hidrocarbonetos despejados irregularmente. Porém, a degradação microbiológica pode ser favorecida por temperaturas adequadas ao crescimento das colônias presentes na região ou adicionadas, ou desfavorecidas por temperaturas mais baixas que podem inibir 0 desenvolvimento dos microrganismos. Outro fator importante na degradação das substâncias presentes nos fluidos de usinagem é a luz solar a qual pode decompor moléculas com grupos absorvedores de radiação eletromagnética. 
Em estudos "in situ", onde os fluidos de usinagem são submetidos à ação de diferentes microrganismos presentes no solo e a fatores ambientais, observa-se uma grande taxa de degradação. Estes resultados sugerem que a ação de fatores ambientais e microrganismos sobre os fluidos de usinagem apresentam maior efeito. Isto sugere que a principal via de degradação não é baseada na absorção dos contaminantes pelos microrganismos, o que teria um efeito tóxico, mas pelo uso de outra fonte de carbono com a conseqüente produção de enzimas ou outras substâncias capazes de oxidar os componentes dos fluidos de usinagem.

Não existe um método único e simples que possa medir a toxicidade de substâncias complexas como os fluidos de usinagem, pois a intensidade e a magnitude destes poluentes para os organismos dependem dos efeitos causados pela presença de fatores não mensuráveis, das interações aditivas, sinérgicas e antagônicas existentes no meio ambiente.

Análises integradas que fornecem informações adicionais e complementares aos testes de toxicidade possibilitam geralmente, a diminuição das incertezas da extrapolação dos resultados obtidos no laboratório para o ambiente real, possibilitando uma avaliação mais abrangente do grau e da extensão da contaminação e dos possíveis riscos associados a esta contaminação.

Os resultados obtidos no estudo da toxicidade de fluidos de usinagem mostraram a necessidade de se aprofundar os estudos das relações e processos biológicos e químicos a fim de diminuir o efeito de possíveis despejos destes fluidos na natureza, fortalecendo os interesses populares na diminuição da carga de poluentes que chegam aos sistemas naturais, sem tratamento adequado.

Em relação às hipóteses propostas neste estudo, a toxicidade encontrada nas amostras de fluido de usinagem de peças metálicas foi muito 
elevada, mostrando que estas substâncias precisam, o mais rapidamente possível, ter sua coleta, transporte, e disposição final, melhor controlados. 


\section{SUGESTÕES PARA TRABALHOS FUTUROS}

Sugere-se que sejam realizados os seguintes estudos:

- Estudos de interação entre os fluidos e os organismos aquáticos por meio de ensaios com mesocosmos;

- Avaliação da degradação dos fluidos usados na usinagem de metais com microrganismos provenientes de ambientes diversos tais como; esgotos domésticos, efluentes de indústrias, sedimentos, entre outros;

- Estudos de degradação dos fluidos de usinagem, "in situ" utilizando as bactérias isoladas em laboratório. 


\section{REFERÊNCIAS BIBLIOGRÁFICAS}

ABEL, P. D. (1998). Water Pollution Biology. $2^{a}$ edição, Ellis Horwood Limited, Chichester, 286p.

ADAMS, S.M. (1990). Status and use of biological indicators for evaluating the effects of stress in fish. Bethesda, American Fisheries Society.

ADAMS, S.M.; BROWN, A. M.; GOEDE, R.W. (1993). A Quantitative Health Assessment Index for Rapid Evaluation of Fish Condition in the Field. Transactions of the American Fisheries Society, n. 122, p. 63-73.

ADAMS, W. J. (1995). Aquatic Toxicology Testing Methods. In: Hoffman, D. J.; Rattnen, B. A.; Burton Jr, G. A.. Handbook of Ecotoxicology. Bocs Raton, Lewis Publishes.

AMARANTE Jr., O. P. de; BRITO, N. M.; RIBEIRO, A. B.; VIEIRA, E. M. (2003). Caracterização de diferentes fluidos empregados na usinagem de metais. Parte I: perfil cromatográfico e espectrometria de massas Anais Assoc. Bras. Quím. v. 52 , n. 2 , p. 83-87.

AMARANTE JR., O. P.; COELHO, R. S.; BRITO, N. M.; et al. (2004). Determinação de microrganismos envolvidos na degradação de fluidos de corte em amostras de solo. In: ESPíNDOLA, E. L. G.; WENDLAND, E. PPG-SEA: trajetórias de um curso multidisciplinar. São Carlos: RiMa.

APHA. - Standard methods for the examination the water and wastewater (1995) .16.ed. Washington, D.C. American Public Health Association, American Water Works Association and Water Pollution Control Federation. 
APHA. - Standard methods for the examination the water and wastewater (1998) .18.ed. Washington, D.C. American Public Health Association, American Water Works Association and Water Pollution Control Federation.

ARAÚJO, A. B.; FÉLIX, E. P.; BRITO, N. M.; AMARANTE Jr., O. P. de. (2004). Interação e destino de pesticidas no ambiente. Ciências da Engenharia Ambiental. v. 3: Ciências Ambientais: diversas abordagens para bacia hidrográfica. São Carlos: RiMa.

ARENZON, A. (2004). Ensaios ecotoxicológicos no monitoramento da qualidade de águas subterrâneas potencialmente impactadas. Porto Alegre, Universidade Federal do Rio Grande do Sul. 94p. Tese (Doutorado em Ecologia).

ASTM - AMERICAN SOCIETY FOR TESTING AND MATERIALS (1988). Standard guide for conducing renewall life cycle toxicity tests with Daphnia magna. Philadelphia: ASTM, 17 p. E1193 - 17.

BAKER, K. H.; HERSON, D. S. (1994). Bioremediation. New York: McGraw-Hill. BASSOI, A. (1990) Avaliação da Toxicidade de despejos Industriais na Região da Grande São Paulo. Dissertação - Instituto de Pesquisas Energéticas e Nucleares (IPEN). Universidade de São Paulo.

BHATTACHARYYA, P.L.; KLERKS, J.A. (2003). Toxicity to freshwater organisms from oils and oil spill chemical treatments in laboratory microcosms. Environmental Pollution. V 122. p 205-215.

BENTHAM, R.; McClURE, N.; CATCHESIDE, D. (1997).Biotreatment of an industrial waste oil condensate. Wat. Sci. Tech., v. 36, n. 10, p. 125-129.

BERTOLETTI, E.; GHERALDI-GOLDSTEIN, E.; ZAGATTO, P. A. (1992). Variabilidade de testes de toxicidade com peixe. Ambiente, v.3, n.1, p. 52.58, São Paulo.

BORRELY, S.I. (2001). Redução da Toxicidade Aguda de Efluentes Industriais e Domésticos Tratados por Irradiação com Feixes de Elétrons, Avaliada com as 
Espécies Vibrio fischeri, Daphnia similis e Poecilia reticulata. Tese - Instituto de Pesquisas Energéticas e Nucleares (IPEN). Universidade de São Paulo.

BRAILE, P.M. (1979). Manual de Tratamento de Águas Residuárias Industriais. São Paulo. CETESB. 764p.

BRANCO, S.M. (1986). Hidrobiologia aplicada a engenharia sanitária. $3^{\mathrm{a}}$ ed. São Paulo: CETESB/ACETESB, 640p.

BRASIL. Agência Nacional do Petróleo (ANP). (1999). Portaria N ${ }^{0} 127$ de 30 de julho de 1999. Regulamenta a atividade de coleta de óleo lubrificante usado ou contaminado a ser exercida por pessoa jurídica sediada no País, organizada de acordo com as leis brasileiras. Diário Oficial da União, Brasília, DF, 02 agosto 1999 .

BRASIL. Agência Nacional do Petróleo (ANP). (1999). Portaria N 129, de 30 de julho de. Estabelece o Regulamento Técnico ANP n004/99, que especifica os óleos lubrificantes básicos de origem nacional ou importado para comercialização em território nacional. Diário Oficial da União, Brasília, DF, 02 agosto de 1999.

BULICH, A. A.(1982). A practical and reliable method for monitoring the toxicity of aquatic samples. Process. Biochem. p. 45.47.

BURNS, K. A.; CODI, S. (1999).Non-volatile hydrocarbon chemistry studies around a production platform on Australia's Northwest shelf. Estuarine, Coastal and Shelf Sci., v. 49, p. 853-876.

BURTON Jr., G.A. \& MACPERSON, C. (1994) Sediment toxicity testing issues and methods. In: HOFFMAN, D.J.; RATTNER, B.A.; BURTON Jr., G.A. \& CAIRNS, Jr., J. (eds.) Handbook of Ecotoxicology. Boca Raton, FL: Lewis Publishers (in press). p. 1-69.

CALVO, C.; TOLEDO, F.L.; GONZÁLEZ-LÓPEZ, J. (2004). Surfactant activity of a naphthalene degrading Bacillus pumilus strain isolated from oil sludge. Journal of Biotechnology, v. 109, p. 255-262. 
CARLSON, R. E. (1977). A Trophic State Index for Lakes. Limnology and Oceanography. Seatle. v.22. p 361-369.

CETESB - Companhia de Tecnologia de Saneamento Ambiental (1990). Procedimentos para Utilização de Testes de Toxicidade no Controle de Efluentes Líquidos - Série Manuais. N. 6. São Paulo, CETESB.

CETESB - Companhia de Tecnologia de Saneamento Ambiental (1991) Teste de toxicidade aguda com Daphnia similis Claus, 1876 (Cladocera, Crustacea). São Paulo: CETESB, 28p. Norma Técnica L5 018.

CETESB - Companhia de Tecnologia de Saneamento Ambiental (1992). Métodos de avaliação da toxicidade de poluentes a organismos aquáticos. São Paulo: CETESB.

CHAPMAN, D.V. (1989). Concepts and Strategies for Biological Monitoring. GEMS. University of London, 45p.

CHARLES, B. \& FREDEEN, K.J. (1997). Concepts, Instrumentation and techniques in Inductively Coupled Plasma Optical Emission Spetrometry Perkin Elmer Corporation.

COELHO, R. S. (2001). Avaliação da Qualidade da Água do Córrego Franquinho, Sub-Bacia Tiquatira / Franquinho, Unidade Hidrográfica do Alto Tietê, São Paulo, SP. Dissertação - Instituto de Pesquisas Energéticas e Nucleares (IPEN). Universidade de São Paulo.

COLEMAN, R. N.; QUERESHI, A.A. (1985). Comparison of three microbial toxicity screening tests with the Microtox test. Bull. Environ. Toxicol. v27.

CURRY, R. D.; RATHBUN, K. (1998). The Nested High-Voltage Generator: An overview of the Technology and Applications. In: Environ. Applic. Of Ioniz. Rad. p33-40.

DANTAS, E. S. K.. (1999). Procedimentos Analíticos em Determinações Multi Elementares de Particulados do Aerossol Atmosférico para uso em Modelo Receptor. Tese de Doutoramento. Instituto de Química, USP, SP. 
D.O.U. - DIÁRIO OFICIAL DA UNIÃO. (2005). Resolução CONAMA $n^{0} 357$, de 17 de março de 2005.

EISENTRAEGER, A.; SCHMIDT, M.; MURRENHOFF, H.; DOTT, W.; HAHN, S. (2002).Biodegradability testing of synthetic ester lubricants - effects of additivies and usage. Chemosphere, v. 48, p. 89-96.

ESTEVES, F. A.. (1988). Fundamentos de Limnologia. Ed. Interciência/FINEP. 570p.

FERNANDES, R. (2001). Modelação de derrames de hidrocarbonetos. [Trabalho final de curso]. Lisboa: Instituto Superior Técnico.

GATTI, L. V. (1997). Distribuição de Metais em Testemunhos de Sedimentos de Duas Lagoas Vizinhas do Rio Mogi - Guaçu (E. E. de Jaí, Luiz Antonio, S.P.) - Tese de doutoramento, USP - São Carlos, São Carlos, S.P.

GULLEY, D.D.,;BOELTER, A.M. \& BERGMAN, H.L. TOXSTAT 3.3.(1991). Computer Program.

GEIS, S. W.; FLEMING, K.; KORTHALS, E.; SEARLE, G.; REYNOLDS, L.; KARNER, D. (2000). Modifications to the algal growth inhibition test for use as a regulatory assay. Environmental Toxicology and Chemistry, 19(1): 36-41.

GRAY, M. R.; BANERJEE, D. K.; DUDAS, M. J.; PICKARD, M. A. (2000).Protocols to enhance biodegradation of hydrocarbon contaminants in soil. Bioremediation J., v. 4, n. 4, p. 249-257.

GREEN, D. A.; NAIMIMOHASSES, R.; SMITH, P. R.; THOMASON, H. (1995).In-situ measurement and classification of oil pollution. Environment Int., v. 21, n. 2 , p. $245-250$.

GREER, C. W.; FORTIN, N.; ROY, R.; WHYTE, L. G.; LEE, K. (2003). Indigenous sediment microbial activity in response to nutrient enrichment and plant growth following a controlled oil spill on a freshwater wetland. Bioremediation J., v. 7, n. 1, p. 69-80. 
HAMILTON, M.A. RUSSO, R.C. \& THURTON, R.V. (1977). Trimed Spearman Karber method for estimating median lethal concentrations in toxicity bioassays. Environmental Science and Technology, New York, v. 11, n. 7, p. 714-719.

HETERS, R.H. \& BERNARDI, R. (1987). Daphnia Consiglio Nazionale Delle Ricerche Instituto Italiano Di Idrobiologia. Verbania Pallanza. Vol.45. 502p.

HOLBEN, W.E.; JANSSON, J.K.; CHELM, B.K.; TIEDJE, J.M. (1988). DNA probe method for the detection of specific microorganisms in the soil bacterial community. Appl. Environ. Microbiol. v. 54, p. 703-711.

IGNATOV, Oleg V.; GULIY, Olga I.; SHCHYOGOLEV, Sergei Yu.; BUNIN, Victor D.; IGNATOV, Vladimir V. (2002). Effect of p-nitrophenol metabolites on microbial cell electro-opticalcharacteristics. FEMS Microbiology Letters, v. 214, p. 81-86.

JEFFREY, D. W. (1987). Biomonitoring of Freshwaters, Estuaries and Shalow Seas: a commentary on requirements for environmental quality control. In: YASUNO, M. eds. Biological Monitoring of Environmental Pollution. Tokyo, $p$ 75 - 90. apud PAMPLIM, P. A.. Z. (1999). Avaliação da Qualidade Ambiental da Represa de Americana (SP-Brasil) com ênfase no estudo da comunidade de macroinvertebrados bentônicos e parâmetros ecotoxicológicos. 112p. Dissertação de Mestrado. São Carlos. São Paulo.

JØRSENSEN, K. S.; PUUSTINEN, J.; SUORTTI, A.-M. (2000).Bioremediation of petroleum hydrocarbon-contaminated soil by composting in biopiles. Environm. Pollution, v. 107, p. 245-254,.

KRAHN, M. M.; YIITALO, G. M.; BUZITIS, J.; CHAN, S.-L.; VARANASI, U.; WADE, T. L.; JACKSON, T. J.; BROOKS, J. M.; WOLFE, D. A.; MANEN, C.-A. (1993). Comparison of high-performance liquid chromatography/fluorescence screening and gas chromatography/mass spectrometry analysis for aromatic compounds in sediments sampled after Exxon Valdez oil spill. Environ. Sci. Technol. v. 27, p. 699-708.

LANGWALDT, J. H.; PUHAKKA, J. A. (2000). On-site biological remediation of contamined groundwater: a review. Environm. Pollution, v. 107, p. 187-197. 
LAWS, E. A. (1993). Aquatic Pollution: an introductory text. 2 ed. New York, John Wiley. P. 192-215; 354-411.

Lemes, M. J. L.L. (2001). Avaliação de metais e elementos-traço em águas e sedimentos das bácias hidrográficas dos rios Mogi-Guaçu e Pardo, São Paulo. Dissertação - Instituto de Pesquisas Energéticas e Nucleares (IPEN). Universidade de São Paulo.

LUBRIFICANTES. [on line]. Disponível em:

http://www.sucatas.com/lubrificante.html. Acessado em 07 de outubro de 2004. MANNIING, W.J.; TIEDMANN, A.V (1995). Climate change: potential effects of increased atmosferic carbon dioxide( $\mathrm{CO} 2)$, ozone (O3) and ultraviolet-B (UVB) radiation on plant desseases - review paper. Environmental Pollution, v. 88, P. 219-145.

MC LAUGHLIN, W. L.; BOYD, A.W. (1989). Dosimetry for Radiation Processing. Ed. Taylor \& Francis. Great Britain.

MICROBICS CORPORATION. (1994). Microtox M500 Manual. A toxicity Testing Handbook, Version 3.

MORASCH, B.; ANNWEILER, E.; WARTHMANN, R. J.; MECKENSTOCK, R. $U$ U. (2001).The use of a solid adsorber resin for enrichment of bacteria with toxic substrates and to identify metabolites. J. Microbiological Methods, v. 44, p. 183191.

MORIARTY, F. (1983). Ecotoxicology - the sudy of polluants in ecosystems. $2^{\text {a }}$ ed.; London, Academic Press.

NAKA, T.; FUJIWARA, N.; YANOC, I.; MAEDAA, S. (2003). Structural analysis of sphingophospholipids derived from Sphingobacterium spiritivorum, the type species of genus Sphingobacterium. Biochimica et Biophysica Acta, v. 1635, p. 83- 92.

NASH, J. F.; GETTINGS, S. D.; DIEMBECKS, W.; CHUDOWSKI, M.; KRAUS, A. L. (1996). A toxicological review of topical exposure to white mineral oils. Fd. Chem. Toxic., v. 34, n. 2, p. 213-225. 
NOCENTINI, M. PINELLI, D.; FAVA, F. (2000). Bioremediation of a soil contaminated by hydrocarbon mixtures: the residual concentration problem. Chemosphere, v. 41, p. 1115-1123.

O'NIELL, W. L.; NZENGUNG, V. A.; NOAKES, J. E.; BENDER, J.; PHILLIPS, P. C. (1999). Biosorption and transformation of tetrachloroethylene and trichloroethylene using mixed-species microbial mats. J. Hazardous Substance Research, v. 2, p. 2.1-2.16.

ÓLEO lubrificante usado. [on line]. Disponível em: <http://www.petroquímicasul.com.br/impusados.htm>. Acesso em 14 de dezembro de 2004.

ORGANISATION FOR ECONOMIC CO-OPERATION AND DEVELOPMENT (OECD) (2002). Draft guidance document on aquatic toxicity testing of difficult substances; 44 pg; Londres.

PESSON, P. (1979). La Contaminacion de Las Aguas Continentales. Ed. Mundi-Prensa. Madrid. 335p.

PIVELI, R.P. (1998). Qualidade das águas. Apostila curso de Pós Graduação. Escola Politécnica de Engenharia/USP. São Paulo.

RAND, G.M.\& PETROCELLI, S.R. (1985) Fundamentals of Aquatic Toxicology. Mc Graw Hill International Book Company, pp. 666.

RAO, R. N. (2002). Computer-assisted analytical techniques in quality assurance of fuels and lubricants. Trends Anal. Chem., v. 21, n. 3, p. 175-186,.

RELA, P. R., SAMPA, M.H.O. (1999). Development of an up-flow irradiation device for electron beam wastewater treatment. Rad. Process. Australia.

RIBBO, J. M.; Zaruk, B. M. (1985). Microtox Toxicity Tests for Water Sample from the Detroit River. J Great Lakes Res. V11. p 297-304.

RICHTER, C.A; NETTO, J.M.A. (1998). Tratamento de Água, Tecnologia Atualizada. Ed. Edgard Blucher LTDA. São Paulo. 332p. 
ROBOTHAM, P. W. J.; GILL, R. A. Input, behaviour and fates of petroleum hydrocarbons. (1989). In: GREEN, J.; TRETT, M. W. The fate and effects of oil in freshwater. New York: Elsevier Science,. p.41-79.

RODRIGUES, L. H. R (2002). Avaliação da sensibilidade de Raphidocelis subcapitata (Chlorococcales, Chlorophyta) ao sulfato de cobre e sulfato de zinco através de testes de toxicidade crônica e determinação da densidade algal por espectrofotometria. Porto Alegre, Universidade Federal do Rio Grande do Sul. 84p. Dissertação (Mestrado em Ecologia).

ROQUES, D. E.; OVERTON, E. B.; HENRY, C. B. (1994). Using gas chromatography/mass spectroscopy fingerprint analyses to document process of oil degradation. J. Environm. Qual., v. 23, p. 851-855.

SALIMOV, R. A.; KUKSANOV, N. K. (1998). Accelerators for Environmental applications an industrial installation for wastewater treatment of a surfaceactive agent. Environ. Applic loniz Rad.

SAMPA, M.H.O.; BORRELY, S.I.; VIERA, J.M. (1993). The use of electron accelerator for the treatment of drinking water and wastewater in Brazil. Radat. Phys. Chem. v 46. p 1143-1146.

SANCHEZ, P. S.; SATO, M.I.Z.; PASCHOAL, C.M.R. (1989). Toxicity assessment of industrial effluents from São Paulo State, Brazil, using short term microbial assays. Toxicity Assessment J. v 3. p 55-80.

SANTOS, E.J. (1999). Determinação de Nutrientes e Contaminantes Inorgânicos em Café Solúvel por Espectrometria de Emissão Atômica com Plasma de Argônio Induzido (ICP-AES). Dissertação de Mestrado - Instituto de Química/USP - SP.

SASSER, M. (1990). Identification of Bacteria by Gas Chromatography of Cellular Fatty Acids. Disponível em: www.midi-inc.com. Acessado em 10 de janeiro de 2003.

SELL, N.J. (1992). Industrial pollution control: issue and techniques. New York, Van Nostran Reinhold, p-1-25. 
SCHROEDER, J. C.; TOLBERT, P. E.; EISEN, E. A.; MONSON, R. R.; HALLOCK, M. F.; SMITH, T. J.; WOSKIE, S. R.; HAMMOND, S. K.; MILTON, D.K. (1997). American Journal of Industrial Medicine, v. 31, p. 525.

SOARES, C.H.L.; MOSIMANN, A.L.P. (1990). Estudo comparativo da toxicidade de efluentes de indústria de papel e celulose utilizando parâmetros bioquímicos. Ecotoxicologia.

SPILBORGHS, M. C. F. (1997). Biorremediação de aqüífero contaminado por hidrocarboneto. Dissertação (Mestrado). Apresentada no Instituto de Geociências. Universidade de São Paulo. Sp. 147p.

TEIXEIRA, N.N. (1987). Influencia dos Detergentes sintéticos biodegradáveis no processo de lodos ativados tratando esgotos predominantemente domésticos; Universidade de São Paulo, Tese de Doutorado; 182 p., São Paulo.

TOLBERT, P. E.; EISEN, E. A.; POTHIER, L. J.; MONSON, R. R.; HALLOCK, M. F.; SMITH, T. J. (1992) Scandinavian Journal Work Environmental Health, v. 18, p. 351.

TRETT, M. W. Introduction. In: GREEN, J.; TRETT, M. W. (1989). The fate and effects of oil in freshwater. New York: Elsevier Science. p.1-10.

U.S. EPA - ENVIRONMENTAL PROTECTION AGENCY (1986). Quality Criteria for Water. Washington DC: EPA.

U.S. EPA - ENVIRONMENTAL PROTECTION AGENCY (1989). Short-term methods for estimating the chronic toxicity of effluents and receiving waters to freshwater organisms. 2.ed. Cincinnati, OH: EPA,. 250p.

U.S. EPA - ENVIRONMENTAL PROTECTION AGENCY (1991). Methods for measuring the acute toxicity of effluents and receiving waters to freshwater and marine organisms. 4.ed. Washington, D.C.: EPA,. EPA - 600/4 - 90/027. 293 p. USEPA-UNITED STATES ENVIRONMENTAL PROTECTION AGENCY. (1993). Methods for measuring the acute toxicity of effluents and receiving waters to freshwater and marine organisms. 5. ed. Washington, D.C.: EPA, 
(EPA - 600/4 - 90/027). UNITED STATES ENVIRONMENTAL PROTECTION AGENCY, 293 p.

U.S EPA -. ENVIRONMENTAL PROTECTION AGENCY (2003). Methods for measuring the acute toxicity of effluents and receiving waters to freshwater and marine organisms. Washington, D.C.: EPA.

VAN DER GAST, C. J.; KNOWLES, C. J.; WRIGHT, M. A.; THOPSON, I. P. , (2001). Identification and characterization of bacterial populations of an in-use metal-working fluid by phenotypic and genotypic methodology. Int. Biodeterioration Biodegradation, v. 47, p. 113-123.

VJVERBERG, J. (1989). Culture Techniques for Studies on the growth, Development and Reprodution of Copepods and Cladocerans Under Laboratory and 'in situ' Conditions: a review. Freshwater Biology. Oxford. v. 21. P. $317-$ 373.

WALSH, F.E.; BAHNER, L.H. (1980). Toxicity of textile mill effluents to freshwater and estuarine algae, crustacean and fish. Environmental Pollution. P $169-179$.

WANG, Z.; FINGAS, M.; PAGE, D. S. Oil spill identification (1999). J. Chromatogr. A.,v. 843, p. 369-411.

WANG, Z.; FINGAS, M.; SERY, G. (1995). Chemical characterization of crude oil residues from an Artic Beach by GC/MS and GC/FID. Environ. Sci. Tech., v. 29, p. 2622-2631.

WANG, Z.; FINGAS, M.; SERGY, G. (1994). Study of 22-year-old arrow oil samples using biomarker compounds by CG/MS. Environ. Sci. Tech., v. 28, n. 9, p. 1733-1746.

WILLIAMS, J. B. (2002).Phytoremediation in wetland ecosystems: progress, problems, and potential. Critical Reviews in Plant Sciences, v. 21, n. 6, p. 607635. 
YABE, M.J.S. (1995). Determinação de Metais Pesados em Águas superficiais por ICP-AES, Objetivando Caracterização e recuperação de Bacias Hidrográficas. Universidade de São Paulo - SP. Tese de Doutorado. 203 pg.

YOUNG, P.; BYRNE, G.; COTTERELL, M., (1997). Int. J. Advanced Manufacturing Technology, v. 13, p. 488.

ZAGATTO, P. A.; BERTOLETTI, E. (2006). Ecotoxicologia Aquática: Princípios e Aplicações. São Carlos. Ed Rima. 478p.

ZIMEK, Z.; CHMIELEWSKI, A.G. (1988). Advanced Accelerator Technology for Environmental Protection. Environ. Applic. Of Ionz. Rad. 